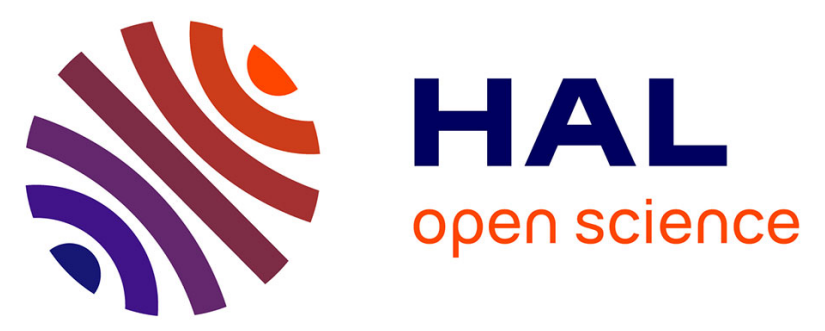

\title{
Fluid circulation along an oceanic detachment fault: insights from fluid inclusions in silicified brecciated fault rocks (Mid-Atlantic Ridge at $13^{\circ} 20^{\prime} \mathrm{N}$ )
}

Anne Verlaguet, D. Bonnemains, C. Mével, J. Escartin, M. Andreani, F. Bourdelle, M-C Boiron, V. Chavagnac

\section{To cite this version:}

Anne Verlaguet, D. Bonnemains, C. Mével, J. Escartin, M. Andreani, et al.. Fluid circulation along an oceanic detachment fault: insights from fluid inclusions in silicified brecciated fault rocks (Mid-Atlantic Ridge at $\left.13^{\circ} 20^{\prime} N\right)$. Geochemistry, Geophysics, Geosystems, 2021, 22 (1), 10.1029/2020GC009235 . hal-03152490

\section{HAL Id: hal-03152490 \\ https://hal.sorbonne-universite.fr/hal-03152490}

Submitted on 25 Feb 2021

HAL is a multi-disciplinary open access archive for the deposit and dissemination of scientific research documents, whether they are published or not. The documents may come from teaching and research institutions in France or abroad, or from public or private research centers.
L'archive ouverte pluridisciplinaire HAL, est destinée au dépôt et à la diffusion de documents scientifiques de niveau recherche, publiés ou non, émanant des établissements d'enseignement et de recherche français ou étrangers, des laboratoires publics ou privés. 


\title{
Fluid circulation along an oceanic detachment fault: insights from fluid inclusions in silicified brecciated fault rocks (Mid-Atlantic Ridge at $13^{\circ} 20^{\prime} \mathrm{N}$ )
}

3

\author{
A. Verlaguet ${ }^{*}$, D. Bonnemains ${ }^{2}$, C. Mével $^{2}$, J. Escartín ${ }^{2,3}$, M. Andreani ${ }^{4}$, F. \\ Bourdelle $^{5}, \mathrm{M}-\mathrm{C}$. Boiron $^{6}, \mathrm{~V}$. Chavagnac $^{7}$
}

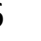

\footnotetext{
${ }^{1}$ Sorbonne Université, CNRS-INSU, Institut des Sciences de la Terre, ISTeP UMR 7193, F 75005 Paris, France

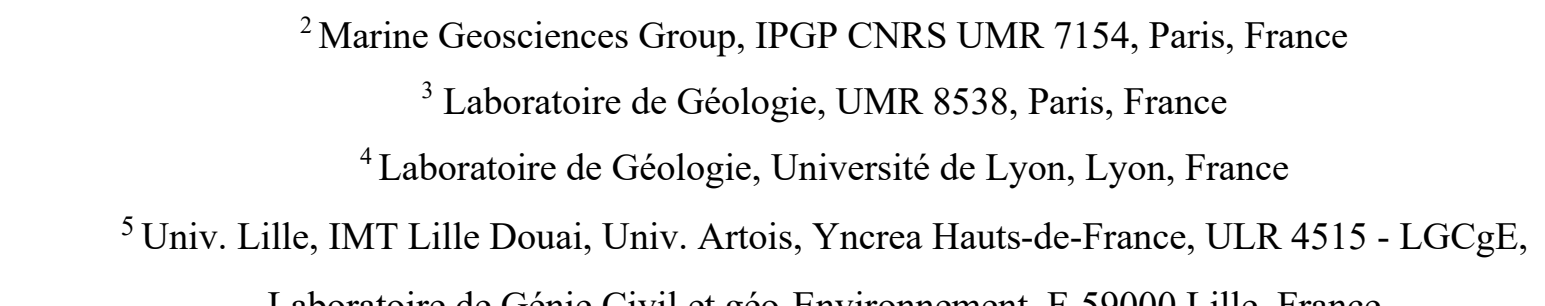

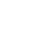

(1)

\section{Keypoints}

3

- MAR $13^{\circ} 20^{\prime} \mathrm{N}$ corrugated detachment fault is composed of pervasively silicified mafic breccias overplated from hangingwall diabases

- Quartz fluid inclusions record mixing of hangingwall silica-rich brines with footwall serpentinite-derived fluids $\left(\mathrm{H}_{2}+\mathrm{CH}_{4}\right)$ in detachment

- This heterogeneous fluid circulation in shallow detachment fault is inconsistent with models of detachments channeling deep fluid flow 


\section{Abstract}

31 The MAR $13^{\circ} 20^{\prime} \mathrm{N}$ corrugated detachment fault is composed of pervasively silicified mafic 32 cataclastic breccias, instead of ultramafics and gabbros commonly found at other detachments.

33 These breccias record overplating of hangingwall diabases, with syntectonic silicification due to 34 important influx of silica-iron-rich fluids, able to leach alkalis and calcium. Fluids trapped in quartz inclusions show important salinity variations (2.1-10 wt.\% $\mathrm{NaCl}$ eq.) indicating supercritical phase separation. Fluid inclusions also contain minor amounts of $\mathrm{H}_{2}+\mathrm{CO}_{2}+\mathrm{CH}_{4}+\mathrm{H}_{2} \mathrm{~S}$, with high $\mathrm{H}_{2} / \mathrm{CO}_{2}$ and $\mathrm{H}_{2} / \mathrm{H}_{2} \mathrm{~S}$ ratios, signatures typical of ultramafic-hosted vent fluids. We propose that seawater infiltrated the hangingwall upper crust at the axis adjacent to the active detachment, reaching a reaction zone at the dyke complex base $(\sim 2 \mathrm{~km})$. At $>500^{\circ} \mathrm{C}$, fluids become Si-rich during diabase alteration (amphibolite-facies alteration in clasts), and undergo phase-separation. Brines, preferentially released in the nearby detachment fault during diabase brecciation, mix with serpentinite-derived fluids bearing $\mathrm{H}_{2}$ and $\mathrm{CH}_{4}$. Cooling during detachment deformation and fluid upward migration triggers silica precipitation at greenschist-facies conditions (quartz+Fe-richchlorite + pyrite). Important variations in fluid inclusion salinity and gas composition at both sample and grain scales record heterogeneous fluid circulation at small spatial and short temporal scales. This heterogeneous fluid circulation operating at $<2 \mathrm{~km}$ depth, extending both along-axis and over time, is inconsistent with models of fluids channeled along detachments from heat sources at the base of the crust at the fault root. Present-day venting at detachment footwall, including Irinovskoe, is instead likely underlain by fluid circulation within the footwall, with outflow crossing the 50 inactive detachment fault near-surface.

\section{Keywords}

53 MAR $13^{\circ} 20^{\prime} \mathrm{N}$, silicified detachment, fluid inclusions, mafic breccias, phase separation, 54 hangingwall overplating 


\section{$59 \quad$ Plain language summary}

60 Here we present constraints on fluid circulation along the $13^{\circ} 20^{\prime} \mathrm{N}$ oceanic detachment fault 61 along the Mid-Atlantic Ridge. Rocks recovered in situ with a deep-sea robot yield mafic breccias, 62 instead of serpentinized mantle rocks commonly found at other detachments. They likely originate 63 from the base of the hangingwall dyke complex, brecciated during fault exhumation. These rocks 64 are intensely silicified (quartz mineralization), resulting from upflow circulation of silica-rich 65 fluids derived from reactions with mafic rocks in a reaction zone. Fluid inclusion (micrometric 66 cavities in quartz crystals that trapped circulating fluid) analyses reveal highly-saline fluids likely 67 formed by phase separation, while traces of hydrogen and methane likely record serpentinization.

68 We thus propose that seawater infiltrated the crust down to a reaction zone at its base ( $2 \mathrm{~km}$ depth), 69 where it became silica-rich by rock hydrothermal alteration. Upon brecciation, these silica-rich 70 brines were released in the detachment where they mixed with fluids coming from footwall rock

71 alteration. Temperature and pressure drops during fluid upflow promoted intense quartz 72 crystallization. The active Irinovskoe hydrothermal site, sitting on the detachment fault $\sim 5 \mathrm{~km}$ off73 axis, is unrelated to fluid circulation in the detachment plane, and likely linked to a heat source 74 within the footwall and directly below it. 


\section{Introduction}

Low-angle detachment faults are common along slow- and ultra-slow spreading ridges, forming primarily at ridge sections with reduced melt supply (Buck et al., 2005; Cannat et al., 2006; Escartín et al., 2008; Tucholke et al., 2008). Rooting deep below the rift valley floor, detachments can operate over long periods of time (up to a few Myrs), exhume deep-seated materials from the oceanic lithosphere, and lead to the formation of oceanic core complexes (OCCs). OCCs are often capped by a fault surface displaying corrugations parallel to spreading. Ridge sections hosting OCCs tend to be associated with high seismicity rates relative to magma-rich, symmetrical ridge sections, and often display active hydrothermal venting (Escartín et al., 2008; Son et al., 2014). The microseismicity along the Northern Atlantic and the Southwest Indian Ridge detachments (deMartin et al., 2007; Parnell-Turner et al., 2017; Tao et al., 2020) reaches sub-Moho depths (between $\sim 8$ and $\sim 13 \mathrm{~km}$ bsf). These results suggest that detachments are associated to a thick lithosphere, and that brittle deformation may provide potential pathways for fluid circulation reaching deep levels. Indeed, fault zone rocks from various OCCs along the MAR display evidence for fluid-rock interactions coeval with deformation. In most cases, the fault zone is characterized by deformed ultramafics and gabbros recrystallized into talcschists and amphibolites, respectively (Boschi et al., 2006; Escartín et al., 2003, 2017; Karson et al., 2006; MacLeod et al., 2002; McCaig et al., 2007; Schroeder \& John, 2004). Moreover, active hydrothermal fields are often found on the OCC surface, with hydrothermal circulation crosscutting pre-existing and/or inactive fault zones, as observed at Rainbow (Andreani et al., 2014), Ashadze (Ondréas et al., 2012), Logatchev (Petersen et al., 2009), Lost City (Fruh-Green et al., 2003) or Von Damm (Hogkinson et al., 2015). To date, however, there is still limited information regarding fluid sources and pathways along the detachment fault zone at depth, the location and nature of heat sources animating this hydrothermal circulation, and the possible links between the hydrothermal activity observed at the surface of these OCCs and the flow along the detachment.

The $13^{\circ} 20^{\prime} \mathrm{N}$ detachment fault, located on the western flank of the Mid-Atlantic Ridge (MAR), exposes a structurally continuous and corrugated detachment fault surface (e.g, Escartín et al., 2017; MacLeod et al., 2009; Smith et al., 2006). While morphology is similar to OCCs elsewhere (Parnell-Turner et al., 2018), sampling of the detachment fault zone reveals unique characteristics. Indeed, while other detachment faults are composed of deformed and hydrated footwall ultramafics and gabbros (Boschi et al. 2006; Escartín et al., 2003, 2016; Karson et al., 2006; MacLeod et al., 

2002; McCaig et al., 2007; Schroeder \& John, 2004), the well-preserved and corrugated $13^{\circ} 20^{\prime} \mathrm{N}$ detachment fault zone is composed essentially of highly silicified mafic cataclastic breccias (Bonnemains et al., 2017; Escartín et al., 2017). These silicified fault breccias likely result from the overplating of mafic material from the base of the hangingwall dyke complex into the footwall during fault exhumation (Bonnemains et al., 2017); these rock types have not been reported from any other studied OCC. The silicified fault zone is $\sim 70 \mathrm{~m}$ or thicker, and the mechanisms of strain localization and fault development leading to a corrugated structure seem to operate independently of lithologies within the fault zone (e.g., Parnell-Turner et al., 2018). Fault zone silicification is evidenced by massive quartz precipitation that may result from elevated fluxes of silica-rich fluids, possibly syntectonic (Bonnemains et al., 2017). This detachment fault surface also hosts the active Irinovskoe hydrothermal site, where several black smokers discharge high temperature fluids (Escartín et al., 2017; MacLeod et al., 2009).

The $13^{\circ} 20^{\prime} \mathrm{N}$ silicified fault rocks, and the fluid inclusions trapped in quartz crystals, provide a unique opportunity to investigate the nature, sources and pathways of fluids circulating within an active detachment fault zone, and to compare them to fluid circulation feeding the active footwall Irinovskoe hydrothermal site. Indeed, to date geochemical and fluid inclusion studies have been conducted on hydrothermally altered rocks from both hangingwall (e.g., Delaney et al., 1987; Humphris et al., 1998; McCaig et al., 2007, 2010; Tivey et al., 1998; Vanko et al., 2004) and footwall of detachments (e.g., Andreani et al., 2014; Boschi et al., 2006; Castelain et al., 2014). However, in these either the link to detachment fault deformation is not established, or the associated hydrothermal systems post-date detachment activity, as in active and inactive systems preserved at the footwall of oceanic detachments (e.g., Andreani et al., 2014; Escartín et al., 2017; Hodgkinson et al., 2015; Ondréas et al., 2012). Thus, studies addressing syntectonic fluid flow at detachments are scarce, and rely on geochemical data from rock samples, (e.g., McCaig et al., 2007, 2010), not from fluids.

To constrain fluid-rock interactions within an active detachment fault zone, here we present a study of fluid inclusions trapped in quartz crystals from silicified fault rocks of the $13^{\circ} 20^{\prime} \mathrm{N}$ OCC. A microthermometric study was conducted on $>100$ fluid inclusions from four representative fault rock samples collected in situ at different outcrops throughout the $13^{\circ} 20^{\prime} \mathrm{N}$ fault zone, and with varying degrees of silicification. Fluid inclusion composition was also investigated by Raman spectroscopy. Whole-rock geochemical analyses were performed to constrain nature and 
composition of the host rocks, and chlorite analyses to constrain the temperature of quartz-chlorite crystallization. With these results and available geological constraints, we propose a model of hydrothermal fluid circulation within an active oceanic detachment fault.

\section{Geological background of $13^{\circ} 20^{\prime} \mathrm{N}$ OCC and sampling}

\subsection{Geological setting}

The $13^{\circ} 20^{\prime} \mathrm{N}$ oceanic detachment displays a structurally continuous fault surface with prominent extension-parallel corrugations, exposed at the seafloor, and that roots at the rift valley floor. This OCC develops on the western flank of the MAR, which spreads at a full rate of $24.6 \mathrm{~mm} / \mathrm{yr}$ (MacLeod et al., 2009; Smith et al., 2008), and is likely active based on its morphology, the absence of late tectonic disruption (Escartín et al., 2017; MacLeod et al., 2009; Mallows \& Searle, 2012), and seismic activity. Microseismicity defines a curved fault plane reaching $>10 \mathrm{~km}$ below the ridge axis (Parnell-Turner et al., 2017), reminiscent of that of other detachments such as TAG (deMartin et al., 2007) or Longqi (Tao et al., 2020). This OCC and its detachment fault were extensively investigated and sampled during the ODEMAR cruise, using deep-sea vehicles (http://www.doi.org/10.17600/13030070). Main cruise results, geological context, details of fault rocks are provided elsewhere (Escartín et al., 2017; Bonnemains et al., 2017).

The exposed, corrugated detachment fault extends $\sim 7 \mathrm{~km}$ in the spreading direction (East-West), and $\sim 5.5 \mathrm{~km}$ perpendicular to the extension (North-South), respectively (Figure 1a; Olive et al., 2019). The microbathymetric corrugations (Figure 1b) have a relief of up to $\sim 10-20 \mathrm{~m}$, and alongextension lengths of a few hundred meters to a maximum of $2 \mathrm{~km}$ (Parnell-Turner et al., 2018). While the detachment fault surface is heavily blanketed by sediment and rubble, fault planes crop out on the flank of these corrugations, showing subhorizontal striations parallel to extension (Escartín et al., 2017). During the ODEMAR cruise, in situ fault rocks were sampled at seven outcrops distributed both along- and across-extension throughout the corrugated detachment fault surface (see numbered circles in Figure 1b). Among these outcrops, Outcrop \#1 (Figure 1b) was in a $\sim 70 \mathrm{~m}$ deep structural low within the detachment fault surface, which shows corrugations throughout. From these observations it was inferred that the fault zone is composed of anastomosing fault planes developing over a thickness of $\sim 70 \mathrm{~m}$ or more (Bonnemains et al., 2017; Escartín et al., 2017; Parnell-Turner et al., 2018). 
The activity of the Irinovskoe hydrothermal field was confirmed during the ODEMAR cruise (Escartín et al., 2017), 1.8 km from the footwall cutoff (black circle in Figure 1b), at a location where samples of sulfides indicated recent or active hydrothermalism (Cherkashev et al., 2013; MacLeod et al., 2009; Pertsev et al., 2012). This site displays two black smoker vents at the summit of hydrothermal mounds (Active Pot and Pinnacle Ridge) venting fluids at $\sim 365^{\circ} \mathrm{C}$, in addition to several inactive mounds and chimneys (Escartín et al., 2017).

\subsection{Detachment fault rocks: lithology and silicification}

A total of 36 fault rocks were recovered in situ from the seven outcrops throughout the $13^{\circ} 20^{\prime} \mathrm{N}$ corrugated detachment fault using ROV Victor 6000, and are described in detail by Bonnemains et al. (2017). All the rocks are cataclastic breccias, with significant heterogeneity in clast abundance and size, and clast/matrix ratios, even at sample-scale (Figure 2). Most breccias contain solely mafic clasts (basalt/diabase; Figure 2a-d), and only 2 of the 36 samples display a mixed lithology, with coexisting mafic and ultramafic clasts (see Figures $1 \mathrm{~b}$ and $2 \mathrm{e}-\mathrm{f}$ ). Several fault rock samples display highly localized deformation with striated slip plane surfaces (Figures 2c-e), as well as complex internal deformation textures, with cataclastic slip zones. Textures record, at the sample scale, several phases of both localized and distributed, penetrative deformation (Bonnemains et al., 2017).

Fault rocks are variably silicified indicating that (1) silica-rich fluids percolated through the fault rocks, and that (2) this silicification (and associated fluid flow) was likely heterogeneous at small spatial (outcrop) scale (Bonnemains et al., 2017). Moderately silicified mafic samples are clastsupported breccias, and contain clasts of hydrothermally altered mafic rocks with still identifiable magmatic textures. Most clasts display a relatively coarse doleritic texture underlined by fresh plagioclase laths (Figure 3b; see Bonnemains et al., 2017 for additional micrographs) indicating a diabase protolith. We have identified a single sample with a clast showing vesicular texture, corresponding to extrusive basalt (Figure 3a). Hence, the bulk of the fault material is incorporated from a dyke complex (Bonnemains et al., 2017), with limited reworking of shallow basalts, and consistent with an efficient exhumation (Olive et al., 2019).

The least silicified diabase clasts show rare relict clinopyroxene, largely replaced by amphibole of hornblende composition, associated to fresh plagioclase of labradorite composition, and no 
associated chlorite (detailed mineral compositions in Bonnemains et al., 2017). This secondary mineral assemblage thus records hydrothermal recrystallization initiated under amphibolite facies conditions $\left(\geq 500{ }^{\circ} \mathrm{C}\right)$. With increasing silicification, amphibole in clasts turns to actinolite, plagioclase becomes more albitic while chlorite crystallizes in clasts too, indicating greenschist facies conditions $\left(\sim 300^{\circ}-500{ }^{\circ} \mathrm{C}\right)$. Clasts in these low to moderately silicified samples are surrounded by a matrix of finely crushed material, with newly formed chlorite and scattered quartz grains ( $<10$ vol.\% quartz). Highly silicified mafic samples are matrix-supported breccias with highly recrystallized clasts whose primary texture is largely obliterated. These breccia clasts are made up almost exclusively of chlorite and quartz, and are surrounded by a quartz-dominated $(>90$ vol.\% quartz) matrix that also contains chlorite. Of the two samples bearing ultramafic clasts, only one has been silicificied. Abundant sulfides associated with quartz are found in three silicified fault rocks.

Cathodoluminescence imaging of selected samples also shows that quartz grains record successive fracturing and recrystallization episodes (Bonnemains et al., 2017), thus consistent with syntectonic quartz crystallization. Silicification and chloritization are closely associated during the alteration of the $13^{\circ} 20^{\prime} \mathrm{N}$ detachment fault mafic breccias. Indeed, chlorite is absent from the freshest diabase clasts (Bonnemains et al., 2017), chlorite content is low in moderately silicified samples and increases significantly with degree of silicification. Chlorite crystals imbricate quartz ones, or are included within quartz crystals, demonstrating co-crystallization in both clasts and matrix. Coeval quartz and chlorite crystallization is also unequivocal within late chlorite-filled veins crosscutting mafic samples. Thus, these microtextures record coeval formation of both minerals during detachment exhumation, and indicate that silicification occurred at greenschistfacies conditions (Bonnemains et al., 2017).

\subsection{Samples selected for fluid inclusion and geochemical study}

This study is based on a set of 6 representative detachment fault rocks that have been selected in order to (1) obtain a spatial coverage throughout the $13^{\circ} 20^{\prime} \mathrm{N}$ corrugated surface, and (2) cover various degrees of alteration and silicification (Table 1; Figure 1). These rocks were sampled in situ from five fault surface outcrops that are described in detail by Bonnemains et al. (2017; Figure 1b). All silicified samples contain abundant albeit very small fluid inclusions in quartz crystals. 
227 Fluid inclusions suitable for this study were identified in 4 samples: three variably silicified 228 breccias with only mafic clasts (ODM195, ODM155 and ODM218), and one silicified breccia with mixed mafic-ultramafic clasts (ODM173). We benchmarked geochemical analyses with two additional unsilicified samples of mafic and mixed mafic-ultramafic material (ODM115 and ODM217, respectively). Sample texture and mineralogy are summarized in Table 1. These samples are heterogeneous, showing a complex history with several deformation phases (Bonnemains et al., 2017), thus subsamples were also taken in some cases at varying distances from slip surfaces, as indicated below. Furthermore, to obtain representative whole-rock chemical analyses, larger subsamples were taken for three samples (i.e., ODM218, ODM173 and ODM217), labeled wr (whole rock) in Tables 2 and S1.

ODM1 15 is a basaltic clast from an unsilicified breccia (Figure 2a). It displays a typical pillow lava microtexture, with skeletal olivine microphenocrysts, radiating dendritic plagioclase, very fine-grained clinopyroxene crystals and vesicles (Figure 3a). Vesicles are filled with chlorite, veins with epidote, and the ground mass contains chlorite and pumpellyite. This quartz-free clast of extrusive basalt is considered as a reference for mafic material incorporated into the fault zone. It is the sole unsilicified mafic sample recovered from the fault outcrops.

ODM195 is a moderately silicified clast-supported breccia (Figure 2b) with clasts composed of either chlorite only, or actinolite + plagioclase \pm chlorite displaying relict doleritic textures (Figure $3 b)$. The matrix contains crushed sub-millimetric clast fragments surrounded by newly formed chlorite and 5-10 vol.\% of quartz (Figure 3b). Anhedral quartz crystals, typically $\sim 100 \mu \mathrm{m}$ in

247 length, are either scattered or in local aggregates in the matrix.

248 ODM155 and ODM218 are two highly silicified, matrix-supported fault breccias (Figures 2c249 d). Both display a striated surface (slip plane) and an underlying well-developed slip zone 250 (penetrative deformation). No primary mineral is preserved in any of the clasts, which contain 251 either chlorite + titanite or chlorite + quartz (Figures 3c-d). Rare clasts preserve a primary doleritic 252 texture (Figure 3c) despite pervasive alteration and mineral replacement, thus indicating a diabase 253 protolith. Anhedral and subhedral quartz grains surrounded by interstitial chlorite represent $>90$ 254 vol.\% of the matrix. Both samples contain abundant sulfides, ODM155 containing only pyrite, 255 whereas ODM218 contains pyrite with minor pyrrhotite and chalcopyrite. 
Three subsamples were taken from ODM218, at varying distance from the slip surface, to investigate relationships between sample geochemistry and distance to slip planes, which may act as preferential fluid flow zones. ODM218a is located within $1 \mathrm{~cm}$ from the striated slip surface (Figure 2d), and contains only rare and submillimetric sulfide grains and clasts embedded in a quartz-rich matrix. When present, clasts are mostly silicified. ODM218b is $\sim 4-5 \mathrm{~cm}$ away from the slip plane, and displays clasts either silicified or quartz-free up to $1 \mathrm{~cm}$ in size, in addition to disseminated quartz grains in the matrix. ODM218c is a fragment dislodged from the lower surface of the sample and away $(\sim 12 \mathrm{~cm})$ from the slip plane, and contains quartz-free clasts surrounded by a silicified matrix with sulfides. In this set of samples, matrix quartz grain sizes increase with the distance to the slip plane, and thus ODM218c contains the largest matrix quartz grains.

ODM217 is a quartz-free, brecciated talc-amphibole schist displaying a slip surface on one side and several internal slip zones (Figure 2e). Clasts are either made up of talc and amphibole or chlorite \pm titanite (Figure 3e). Matrix mineralogy varies among slip zones, and is made of talc, serpentine or chlorite (Figure 3e), with disseminated spinels. To account for sample heterogeneity, two subsamples were taken (Figure 2e). Subsample ODM217a is a chlorite-rich slip zone adjacent to a striated slip surface, whereas subsample ODM217b is a talc-rich zone a few cm away from this same slip surface. For whole-rock geochemical analyses, we thus consider the unsilicified breccia ODM217 as a reference, as it contains both ultramafic and mafic clasts.

ODM173 is a matrix-supported breccia (Figure 2f) containing both mafic and ultramafic clasts, made of talc or chlorite \pm titanite (Figure $3 \mathrm{f}$ ). The matrix is made of chlorite and talc, with variable amounts of quartz at the sample scale, and scattered spinel and sulfides (chalcopyrite + pyrite; Figure 3f). As for ODM217, we selected two sub-samples to investigate this heterogeneity. ODM173a displays few small clasts $(<1 \mathrm{~mm})$ surrounded by a silicified matrix made of chlorite and talc associated with anhedral quartz crystals ( $<60$ vol.\% quartz, Figure $3 \mathrm{f})$, whereas clasts in ODM173b are more abundant and larger (up to 1-2 $\mathrm{cm}$ ), with only rare quartz grains and minor chlorite in the matrix. Sulfides are more abundant in ODM173b than in ODM173a.

\section{Methods}

To investigate the composition of fluids circulating through the detachment fault zone, and that are responsible for pervasive silicification, a study of fluid inclusions trapped in quartz crystals was 
coupled to whole-rock and mineral geochemical analyses (major and trace element). Fluid inclusion analyses included microthermometry, Raman spectroscopy, and LA-ICP-MS. We also used SEM-cathodoluminescence to study the growth history of quartz crystals hosting fluid inclusions. Microthermometric measurements of fluid inclusions determined isochoric relationships that, coupled with geologically constrained pressure intervals, provided estimates of fluid inclusion entrapment temperatures. These temperatures were then compared to silicification temperatures inferred from the composition of chlorite co-crystallized with quartz, using the geothermometer of Bourdelle et al. (2013).

\subsection{Whole-rock and mineral chemical analyses}

Whole rock chemical analyses were performed at the SARM-CRPG (Nancy, France). Major elements were analyzed by inductively coupled plasma optical emission spectroscopy (ICP-OES) after fusion with $\mathrm{LiBO}_{3}$ and dissolution in $\mathrm{HNO}_{3}$. Trace elements were quantified by inductively coupled plasma mass spectrometry (ICP-MS) following the procedure described by Carignan et al. (2001). To account for sample heterogeneity, subsamples were analyzed for ODM218, ODM173 and ODM217 (see section 2.3).

Major element composition of chlorite was analyzed by EPMA (CAMECA SX-FIVE, CAMPARIS, Sorbonne Université, Paris, France). Analytical conditions were 15 kV-10 nA in WDS mode, for analysis of major elements. $\mathrm{Fe}_{2} \mathrm{O}_{3}(\mathrm{Fe}), \mathrm{MnTiO}_{3}(\mathrm{Mn}, \mathrm{Ti})$, diopside $(\mathrm{Mg}, \mathrm{Si}), \mathrm{Cr}_{2} \mathrm{O}_{3}$ $(\mathrm{Cr})$, orthoclase $(\mathrm{Al}, \mathrm{K})$, anorthite $(\mathrm{Ca})$ and albite $(\mathrm{Na})$ were used as standards for elements in parentheses. Only chlorite analysis with oxide sum in the $86-89$ wt. $\%$ range and $\mathrm{Na}_{2} \mathrm{O}+\mathrm{K}_{2} \mathrm{O}+$ $\mathrm{CaO}<1$ wt.\% were considered. Structural formulas were derived on a 14-oxygen basis. Chlorite analyses with $\mathrm{Si} \leq 4$ atoms per formula unit, cation sum $\leq 10.1$ apfu and vacancies $>0.01$ pfu were considered. In situ trace element analyses were carried out on 22 chlorites at GeoRessources (Nancy, France) using LA-ICP-MS. Technical details can be found with results in Table S3.

\subsection{Fluid inclusion analyses}

Fluid inclusions analyses were performed on $100 \mu \mathrm{m}$ thick double-polished sections. Successive generations of fluid inclusions trapped during quartz crystal growth were first characterized using 
an Olympus BX-50 transmitted light microscope at IPGP. Inclusions either isolated or clustered (i.e., distant less than five times their length; Figure 4a) are considered as primary according to the criteria of Roedder (1984) and Van den Kerkhof and Hein (2001), whereas those located along trails crosscutting quartz grains are considered as secondary (Figure $4 \mathrm{~b}$ ). The location of the different generations of fluid inclusions within individual quartz crystals was compared to crystal growth history as revealed by SEM-cathodoluminescence observations (as in Boiron et al., 1992), conducted at ISTeP - Sorbonne Université (Paris, France) on a Scanning Electron Microscope Zeiss Supra 55 equipped with an EDS system and an Oxford Instruments cathodoluminescence system.

Microthermometric fluid inclusion measurements were carried out at ISTeP - Sorbonne Université under an optical microscope equipped with a Linkam THMSG 600 heating-freezing stage with temperatures ranging from $-196{ }^{\circ} \mathrm{C}$ to $+600{ }^{\circ} \mathrm{C}$. The stage is controlled by a Linkam TMS 93 programmer via LinkSys software v.2.15.

Cycles of repeated homogenization and ice melting temperature measurements were conducted on 176 individual inclusions to measure the temperature of phase changes for the gas-to-liquid homogenization (temperature of homogenization, Th) and for the ice melting point (temperature of final ice melting, $\mathrm{Tm}_{\mathrm{ice}}$ ), respectively. Several cycles performed to test reproducibility show that ice melting and homogenization temperatures were reproducible within $0.1{ }^{\circ} \mathrm{C}(\sim 0.2 \mathrm{wt} . \%$ eq. $\mathrm{NaCl}$ ) and $1{ }^{\circ} \mathrm{C}$, respectively. Inclusions yielding non-reproducible measurements systematically showed complex morphologies and were thus discarded, yielding 119 fluid inclusions for this study. We performed temperature cycles in the potential range of hydrate melting temperatures, following Raimbourg et al. (2014), but no gas hydrate was detected. Salinity was estimated from $\mathrm{Tm}_{\text {ice }}$ using the equation in Bodnar (1993), assuming that the entrapped fluid is a pure $\mathrm{H}_{2} \mathrm{O}-\mathrm{NaCl}$ solution. Isochoric P-T relationships followed by fluid inclusions were derived from $\mathrm{Th}$ and $\mathrm{NaCl}$ molality, following the equation of Zhang and Frantz (1987), suitable for our P-T and salinity range.

Gas content of fluid inclusions was analyzed with a Dilor-Labram Raman microspectrometer at GeoRessources (Nancy, France) on a representative set of 83 inclusions. As all studied inclusions are two-phase, we focused the laser on the gas bubble to determine gas proportions. In these dominantly aqueous inclusions, $\mathrm{H}_{2} \mathrm{O}$ vapor is by far the dominant gaseous phase. The relative molar proportions of the remaining minor gases $\left(\mathrm{H}_{2}, \mathrm{CO}_{2}, \mathrm{CH}_{4}, \mathrm{H}_{2} \mathrm{~S}\right)$ were calculated with accuracy better 
than 5\% (Pasteris et al., 1988) following the procedure described in Dubessy et al. (1989). This

346 involves band area integration at wavenumbers of each gas and gas specific volume, i.e., Raman 347 scattering cross-section for each gas and instrument efficiency at the specific wavenumbers 348 (Frezzotti et al., 2012). To subtract the air signal for $\mathrm{N}_{2}$, we conducted blank analyses in the quartz 349 immediately adjacent to each inclusion.

$350 \quad$ Fluid inclusion chemical composition was analyzed on all inclusions larger than $8 \mu \mathrm{m}$ (i.e., 24 351 inclusions) with a LA-ICP-MS at GeoRessources (Nancy, France; see technical details in Table 352 S3). We analyzed $\mathrm{Na}, \mathrm{K}, \mathrm{Li}, \mathrm{Mg}, \mathrm{Fe}, \mathrm{Mn}, \mathrm{Cr}, \mathrm{Co}, \mathrm{Ni}$, and calculated absolute concentrations and 353 limits of detection following Leisen et al. (2012), using $\mathrm{Na}$ content derived from 354 microthermometric $\mathrm{Tm}_{\text {ice }}$ measurements (and calculated salinity) as internal standard. However, 355 due to the low signal intensity for most measured elements, it was impossible to calculate accurate 356 fluid inclusion element concentrations; these fluid inclusions were very small, with fluid released 357 after 1-2 laser shots, and contained low salinity fluids that are therefore very diluted in metallic 358 elements. While $\mathrm{Na}$ is likely the most concentrated cation, it was systematically difficult to detect 359 by LA-ICP-MS due to ionization problems.

\section{Results}

\subsection{Chemistry}

\subsubsection{Whole rock analyses}

Major element compositions and selected trace element contents for samples described in Section 2.3 are presented in Table 2 (see Table S1 for full trace element analysis). Chemical data are compared with published data of mafic and ultramafic rocks recovered at the $13^{\circ} 20^{\prime} \mathrm{N}$ OCC (Wilson et al., 2013), and at the 15²0’N Fracture Zone (Godard et al., 2008; Paulick et al., 2006), although such comparison must be done with care as $13^{\circ} 20^{\prime} \mathrm{N}$ fault rocks are breccias, and differ from those at other sites, as presented above.

$3725 \mathrm{a} ; \mathrm{Na}_{2} \mathrm{O}$ and $\mathrm{Al}_{2} \mathrm{O}_{3}$ in Figures $\mathrm{S}$ la-b) decreases sharply with increasing Si content, with almost 373 complete depletion in the highly-silicified samples ODM155 and ODM218. Mg\# for basaltic 
374 ODM115 and moderately silicified diabase ODM195 are in the range of MAR basalt and diabase 375 values (Figure 5b). In contrast, Mg\# clearly decreases in highly silicified samples ODM155 and 376 ODM218 $(\mathrm{Mg} \#<45)$. Mixed mafic-ultramafic breccias show compositions that are intermediate 377 between MAR mafic and ultramafic compositions, resulting from mafic and ultramafic material 378 mixed in variable amounts (Figures 5a-b and $\mathrm{Sla}-\mathrm{b}$ ). As in mafic samples, $\mathrm{CaO}, \mathrm{Na}_{2} \mathrm{O}$ and $\mathrm{Al}_{2} \mathrm{O}_{3}$ 379 contents, as well as Mg\#, are significantly lower in the silicified sample ODM173 compared to unsilicified ODM217 (Figures 5a-b and S1a-b). Their $\mathrm{SiO}_{2}$ content is higher than that of ultramafic rocks for both the silicified ODM173 and the unsilicified ODM217, which is talc-rich.

$\mathrm{Cr}$ and Ni concentrations (Figure 5c) in most mafic samples are similar to those of MAR basalts and diabases, with subsample ODM218b showing slightly higher contents in both $\mathrm{Cr}$ and Ni. For the two samples with both mafic and ultramafic clasts, $\mathrm{Cr}$ and $\mathrm{Ni}$ contents are intermediate between those of MAR mafic and ultramafic compositions, reflecting again their mixed lithologies. The REE patterns (Figure S1c) for all mafic breccias are flat, as observed for MAR basalt and diabase patterns (Wilson et al., 2013). While the unsilicified basaltic clast ODM115 displays REEnormalized values consistent with those of MAR mafic rocks, REE concentrations progressively decrease as silicification increases, but without any pattern modification, likely due to dilution by quartz crystallization. The two mafic-ultramafic fault rocks display REE patterns between those of mafic and ultramafic signatures, reflecting their mixed lithologies (Figure S1c).

Hence, bulk rock analyses reflect significant heterogeneity of breccia samples, controlled by both the degree of silicification and the nature of the clasts. However, such analysis only reveals relative elemental enrichment or depletion. We combine these chemical analyses to textural and mineralogical observations to constrain effective mass transfer, and to determine if silicification resulted from significant silica enrichment only, or was associated to efficient leaching of other elements. Several arguments indicate massive silica influx rather than an important leaching: (1) dilution effect observed for most trace elements (Figure S1c), (2) preferential preservation of initial textures with well-defined clast borders, which would have been erased by massive leaching, (3) 400 the fact that the most silicified breccias are matrix supported (while less silicified ones are clast401 supported), and (4) the preferential crystallization of quartz in the matrix. However, calcium and 402 alkalis (and part of the aluminum) were almost completely leached from silicified mafic and mixed 403 mafic-ultramafic samples, and this important decrease with increasing silicification cannot be 404 explained solely by passive depletion due to quartz crystallization (grey arrows, Figures 5a and 
S1a-b). Almost complete alkali leaching is also supported by mineralogical composition of all mafic fault rocks from the seven outcrops (Bonnemains et al., 2017). Indeed, highly silicified samples contain mainly chlorite and quartz, lacking mineral phases able to host alkalis (i.e., no plagioclase or amphibole in highly silicified samples ODM218 and ODM155). The decrease in $\mathrm{Mg} \#$ for silicified samples (ODM155, ODM218 and ODM173) compared to unsilicified ones likely reflects iron enrichment, as $\mathrm{Mg \#}$ would be unaffected by quartz crystallization (Figure 5b). This is supported by the growth of iron-rich sulfides, essentially pyrite, as confirmed by the low $\mathrm{Cu}$ and $\mathrm{Zn}$ content (Table 2).

\subsubsection{Chlorite composition}

Microprobe analyses show that chlorites from both mafic and mixed mafic-ultramafic samples contain $40-50$ wt.\% of $\mathrm{FeO}+\mathrm{MgO}, 30-40$ wt. $\% \mathrm{SiO}_{2}$ and $15-25$ wt.\% $\mathrm{Al}_{2} \mathrm{O}_{3}$ (Figure 6a). There is no systematic difference in chlorite composition between clasts and matrix for each sample (Figure 6a). Chlorites in moderately silicified ODM195 show slightly lower $\mathrm{FeO}+\mathrm{MgO}$ and higher $\mathrm{SiO}_{2}$ contents than highly silicified ODM218, while chlorite composition of highly silicified ODM155 overlaps both samples.

Chlorites contain $\mathrm{Si}$ apfu in the range 2.7-3.5, $\mathrm{Al}$ apfu is 1.5-2.6 and $\mathrm{Mg} \#$ between 43 and 85 (Table S2). While Si and Al contents are clearly anticorrelated for all chlorites, Si content and Mg\# are roughly correlated in each sample, although more scattered (Figure 6b). The unsilicified basalt sample (ODM115) has chlorite compositions similar to those from MAR basalts (Alt et al., 1985; Gillis \& Thompson, 1993; Humphris \& Thompson, 1978). Chlorite composition in moderately silicified breccia (ODM195), in both clast and matrix, is comparable to that in diabases (amphibolite facies; Castelain et al., 2014; Escartín et al., 2003; Figure 6b). For highly silicified samples (ODM155 and ODM218), chlorites clearly have a lower Mg\# compared to ODM195, with a wider range (about 80-40), although most of them remain comparable to oceanic basalt chlorites (Figure 6b). Increasing silicification is obviously associated with iron enrichment and silica depletion in chlorites, a trend also observed by Saccocia and Gillis (1995) and Delaney et al. (1987) in the MARK area, and by Castelain et al. (2014) in diabase chlorite-quartz veins at the footwall of the Atlantis Massif detachment (Figure 6b). Indeed, iron-rich chlorites have been described in oceanic hydrothermal breccias and quartz veins associated with the dyke complex or the dyke-lava 
transition (Alt et al., 1985; Delaney et al., 1987; Honorez et al., 1998; Humphris et al., 1998; Mottl, 1983; Saccocia \& Gillis, 1995).

Concerning mixed mafic-ultramafic breccias, chlorites from the unsilicified sample ODM217 show the highest $\mathrm{Mg} \#$ at $\sim 80$. This is expected in rocks containing fragments of ultramafic rocks, and are mostly comparable to chlorites from other oceanic detachment talcschits and amphibolite schists (e.g., 15²5'N, Escartín et al., 2003; South Atlantis massif, Boschi et al., 2006; Figure 6b). $\mathrm{Mg} \#$ for chlorites in the silicified mixed breccia (ODM173) presents a broader range and lower values (Mg\# 50-80) than those of talcschists (Mg\# 80, Figure 6b), similar to the decrease in $\mathrm{Mg} \#$ and $\mathrm{Si}$ with increasing silicification observed for mafic samples.

Concerning trace elements, chlorites from mixed mafic-ultramafic fault rocks are generally enriched in $\mathrm{Cr}, \mathrm{Ni}, \mathrm{Co}$, but depleted in $\mathrm{Ti}, \mathrm{V}, \mathrm{Mn}$ compared to chlorites from mafic breccias (Tables S2 and S3), in line with literature data (e.g., chlorites from diabases and talcschists, Boschi et al., 2006; Escartín et al., 2003). We note that a few chlorites from highly silicified mafic samples (ODM155 and ODM218) also show enrichments in $\mathrm{Cr}$, Co, and slight enrichments in $\mathrm{Ni}$ (Tables $\mathrm{S} 2$ and S3).

\subsubsection{Calculated temperature of chlorite formation}

Several chlorite thermometers exist in the literature, based on empirical, semi-empirical, or thermodynamic approaches. Empirical thermometers cannot be used here as their application is restricted to the chlorite compositional space used for their calibration (Bourdelle \& Cathelineau, 2015). Furthermore, their applicability is questionable as they only consider one substitution, do not take into account the bulk rock composition, and have no thermodynamic basis (Bourdelle \& Cathelineau, 2015). Thermobarometric models (e.g., Vidal \& Parra, 2000; Vidal et al., 2001, 2005, 2006; Walshe, 1986), widely used in metamorphic environments, lack of thermodynamic data for the Si-rich Al-free chlorite end-member (Figure 6c), therefore precluding their use for our samples. Indeed, chlorites formed in the fault breccias (Figures 6b-c) have a relatively high Si content (2.7$3.5 \mathrm{apfu}$ ) and some chlorites plot in the clinochlore-sudoite-Al-free chlorite field (Figure 6c). We thus used the semi-empirical geothermometer of Bourdelle et al. (2013), suitable for all compositions of chlorite in equilibrium with quartz. This choice is also comforted by the quartz 
and chlorite co-crystallization in both matrix and clasts during silicification (see 2.2 and Bonnemains et al., 2017).

The geothermometer of Bourdelle et al. (2013) is specifically calibrated for low-temperature contexts (i.e., $\mathrm{T}<350{ }^{\circ} \mathrm{C}$ ), through a linear equation linking the chlorite + quartz equilibrium constant to the temperature of crystallization, taking into account cationic substitutions involving $\mathrm{Si}$ and $\mathrm{R}^{2+}$ contents. For higher-grade contexts, several thermodynamic parameters (as the nonideal contribution of the site mixing) cannot be linearized, and a quadratic correction (Bourdelle et al., 2013) is proposed instead ("Tcorrected" in Table S2). While these "Tcorrected" results should be cautiously considered (Bourdelle et al., 2013), this involves a small portion of our analyses.

Temperatures obtained with this thermometer mostly span the $150-400{ }^{\circ} \mathrm{C}$ range (except for a few outliers which are not considered). We find median temperatures of $\sim 250^{\circ} \mathrm{C}$ for the moderately silicified samples ODM173 and ODM195, and $\sim 275$ and $\sim 300{ }^{\circ} \mathrm{C}$ for the highly silicified samples ODM155 and ODM218 respectively (Figure 6d; Tables S2 and S4).

\subsection{Fluid inclusion results}

\subsubsection{Distribution and morphology of fluid inclusions}

Fluid inclusions are common in quartz from the $13^{\circ} 20^{\prime} \mathrm{N}$ detachment fault rocks. Those in quartz crystals from clasts in highly silicified breccias are bigger and better preserved than those in quartz grains within the matrix, which shows abundant decrepitated inclusions. All inclusions contain aqueous fluid that is two-phase (liquid-vapor; Figure 4) at room temperature, with a vapor to total volume ratio ranging from 0.1 to 0.5 (Figure S2). In quartz grains distant from slip planes $(>1 \mathrm{~cm}$ ), fluid inclusions are abundant and mostly range in size from 8 to $12 \mu \mathrm{m}$ (Figure $4 \mathrm{a}$ ). The contour of primary fluid inclusions is spherical to elongated, sometimes approaching negative crystal shapes (Figures 4a, d, e, i). No sign of decrepitation (e.g., Roedder, 1984; Touret, 2001) is noticeable, except in samples within $\sim 1 \mathrm{~cm}$ from a slip plane (sample ODM218a), in which inclusions are small $(<5 \mu \mathrm{m})$, very irregular in shape, and often empty and probably decrepitated (e.g., Roedder, 1984). Inclusions in this sub-sample ODM218a were therefore discarded for microthermometric measurements. 
Small and elongated fluid inclusions, a few microns thick and a few tens of micron long, are regularly distributed, defining trails. Their elongation is often slightly oblique to the trail direction 494 (Figures 4b, c, f, g, h), but their vapor ratio is similar to that of primary inclusions (Figure S2). These correspond to recrystallized microfractures, and thus postdate primary ones described above (e.g., Roedder, 1984). These trails do not show any distinct orientation, neither relative to each other nor at the sample scale (Figures $4 \mathrm{f}, \mathrm{g}$ ). Most of them are intra-grain trails, as they remain within the limits of quartz grains (Van den Kerkhof \& Hein, 2001), with few occurrences crosscutting grain boundaries (Figures $4 \mathrm{f}, \mathrm{g}$ ). These trails are thus related to quartz fracturing between successive quartz crystallization episodes as revealed by SEM cathodoluminescence (Figures 7 and S3; Bonnemains et al., 2017). Therefore, this second set of inclusions can be classified as "pseudo-secondary", following the criteria of Roedder (1984).

\subsubsection{Microthermometry}

Ice melting temperature $\left(\mathrm{Tm}_{\mathrm{ice}}\right)$ measurements indicate that all inclusions, primary and secondary, contain moderately saline aqueous fluids. $\mathrm{Tm}_{\text {ice }}$ ranges from $-6^{\circ} \mathrm{C}$ to $-1.5^{\circ} \mathrm{C}$ (Figure $\mathrm{S} 4$ ), yielding equivalent salinities ranging from 2.1 to $\sim 10 \mathrm{wt} \%$ eq. $\mathrm{NaCl}$. Most fluid inclusions studied here thus have a salinity higher than that of seawater $(3.2 \mathrm{wt} \%$ eq. $\mathrm{NaCl}$, blue line in Figure

8a; Table 3) with salinity restricted to the 4-6 wt.\% eq. $\mathrm{NaCl}$ range for all samples but ODM218, which displays a wider salinity range (2.1-10 wt.\% eq. $\mathrm{NaCl})$. We note that the salinity is higher for subsample ODM218b (from 6.3 to $10 \mathrm{wt} \%$ eq. $\mathrm{NaCl}$ ) than for subsample ODM218c (from 2.1 to 6.1 wt.\% eq. $\mathrm{NaCl}$; Figure $8 \mathrm{a})$.

Highly silicified mafic breccias (ODM155, ODM218) present higher homogenization temperatures $\left(180-350^{\circ} \mathrm{C}\right)$ than moderately silicified ones, either mafic (ODM195) or mixed mafic-ultramafic (ODM173; 150-220 ${ }^{\circ} \mathrm{C}$; Figure 8a; Table 3). The highly-silicified sample ODM155 shows a wide range of Th values, spreading over $\sim 130{ }^{\circ} \mathrm{C}$, whereas the $\mathrm{Th}$ for all other samples show more restricted ranges of up to $90^{\circ} \mathrm{C}$. We do not observe any systematic difference in $\mathrm{Tm}_{\mathrm{ice}}$ and Th between primary and secondary fluid inclusions in any of the samples (Figure 8a).

519 Intra-grain variations of fluid inclusion Th and salinities are shown in Figure 8b, where sets of inclusions from different quartz grains are shown with different colors. The strong variation of Th 
silicified mafic breccias) is thus observed not only at the sample scale, but also at the quartz grain scale (Figure 8b). SEM-cathodoluminescence observations reveal core-to-rim variations in quartz luminescence (Figures 7 and S3) that record successive steps of quartz crystallization (Bonnemains et al., 2017). The location of fluid inclusions displaying scattered microthermometric values on cathodoluminescence images (Figure 7b, $\mathrm{d}$ and $\mathrm{S} 3 \mathrm{~b}, \mathrm{e}$ ) suggests that fluid inclusions were trapped in quartz of varying luminescence, and thus during different quartz grain crystallization phases, between successive quartz fracturing episodes.

\subsubsection{Composition of fluid inclusions}

Fluid inclusions from the 4 fault rock samples studied here are mostly aqueous (i.e., $\mathrm{H}_{2} \mathrm{O}-\mathrm{NaCl}$ ), as shown by the absence of gas hydrate detection. Raman spectroscopy analyses of the vapor phase (i.e., gas bubble) of aqueous fluid inclusions detected minor amounts of $\mathrm{H}_{2}, \mathrm{CO}_{2}, \mathrm{CH}_{4}$ and $\mathrm{H}_{2} \mathrm{~S}$ (in addition to $\mathrm{H}_{2} \mathrm{O}$ ) in the highly silicified mafic breccias (ODM155 and ODM218; Table 3; Figure 9). Conversely, only $\mathrm{H}_{2} \mathrm{O}$ vapor was detected in the moderately silicified samples ODM173 and ODM195, although the high fluorescence observed during Raman analyzes for the latter could have hidden small gas signal.

In sample ODM155, only two out of 17 fluid inclusions (Table 3) were not purely aqueous and contained traces of $\mathrm{CO}_{2}$. On the other hand, 15 out of 28 inclusions from subsample ODM218b, and the 21 analyzed inclusions of ODM218c, contained traces of gases (other than $\mathrm{H}_{2} \mathrm{O}$ ), and dominated by $\mathrm{H}_{2}$ (up to 100 mol.\% of the $\mathrm{H}_{2}-\mathrm{CO}_{2}-\mathrm{CH}_{4}-\mathrm{H}_{2} \mathrm{~S}$ content in 18 inclusions) in addition to variable proportions of $\mathrm{CO}_{2}$ (up to $80 \mathrm{~mol} \%$ of the $\mathrm{H}_{2}-\mathrm{CO}_{2}-\mathrm{CH}_{4}-\mathrm{H}_{2} \mathrm{~S}$ content), $\mathrm{CH}_{4}$ (up to 12 mol. $\%$ of the $\mathrm{H}_{2}-\mathrm{CO}_{2}-\mathrm{CH}_{4}-\mathrm{H}_{2} \mathrm{~S}$ content) and $\mathrm{H}_{2} \mathrm{~S}$ (up to $12 \mathrm{~mol} . \%$ of the $\mathrm{H}_{2}-\mathrm{CO}_{2}-\mathrm{CH}_{4}-\mathrm{H}_{2} \mathrm{~S}$ content, in 4 inclusions from ODM218c; Figure 9a). All inclusions display very low $\mathrm{H}_{2} \mathrm{~S} / \mathrm{H}_{2}$ ratios (Figure $9 b$ ), similar to those measured in ultramafic-derived hydrothermal vent fluids (Fouquet et al., 2010), while mafic hosted vents rather show high $\mathrm{H}_{2} \mathrm{~S} / \mathrm{H}_{2}$ ratios. We do not observe any correlation between gas compositions and microthermometric data (Figure S5).

LA-ICP-MS analyses were performed on a set of 24 fluid inclusions, but their small size precludes calculating reliable concentrations (see 3.2). $\mathrm{K}+/-\mathrm{Na}$ and $\mathrm{Li}$ were detected in 10 inclusions, and associated to the presence of $\mathrm{Cr}+/-\mathrm{Ni}, \mathrm{Co}, \mathrm{Mn}, \mathrm{Fe}, \mathrm{Mg}$ in 7 of them. Despite these limitations due to inclusion sizes, inclusion fluids in the $13^{\circ} 20^{\prime} \mathrm{N}$ detachment fault rocks appear to 
be very diluted fluids. They can thus be assimilated to fluids in the $\mathrm{H}_{2} \mathrm{O}-\mathrm{NaCl}$ system, and hence their salinity can be estimated from the ice melting temperature (Bodnar, 1993).

\section{Interpretation and discussion}

\subsection{Pressure and temperature conditions of silicification}

\subsubsection{Pressure range deduced from the geological context}

Silicification occurred in the detachment plane, affecting cataclastic breccias of mainly mafic composition. Preserved doleritic textures in moderately silicified breccias indicate that these diabase rocks were part of the base of Layer 2 (dyke complex) at the hangingwall, underlying the rift valley floor, and mechanically accreted into the fault zone (Bonnemains et al., 2017). Geophysical observations along slow-spreading ridges suggest that Layer 2 thickness may vary between 1 and $2 \mathrm{~km}$ (see discussion in Bonnemains et al., 2017 and references therein), while a recent seismic experiment in this study area reports a Layer $2 \mathrm{~A}$ thickness on-axis of $\sim 2 \mathrm{~km}$ (Simão et al., 2020). Assuming a rift valley floor depth of $\sim 3000 \mathrm{~m}$, and considering seawater and crustal rocks densities of 1025 and $3000 \mathrm{~kg} \cdot \mathrm{m}^{-3}$ respectively, the pressure ranges for the base of Layer 2 can be estimated to 600-890 bars for lithostatic pressure, and 400-500 bars for hydrostatic pressure. Therefore, silicification and coeval fluid entrapment in quartz crystals in the detachment fault zone necessarily took place between the base of Layer 2 (400-890 bars) and the seafloor (300 bars; Figure 10).

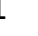

\subsubsection{Temperature of fluid inclusion trapping during silicification}

Fluid inclusion isochores derived from microthermometric data (equation of Zhang \& Frantz, 1987) represent the P-T relationship along which fluid inclusions were trapped (Figure 10), while the measured homogenization temperature Th (Figure 8) indicates the rooting temperature of the isochore on the liquid-vapor curve (from Sourirajan \& Kennedy, 1962). Intersection of fluid pressure ranges (see above) with isochores provides an estimate of the temperature range of silicification and subsequent fluid entrapment in quartz crystals (Figure 10). For samples ODM195 and ODM173, temperatures of fluid entrapment are in the $160-280{ }^{\circ} \mathrm{C}$ range, while for highly silicified samples ODM155 and ODM218, entrapment temperatures are in the $200-400{ }^{\circ} \mathrm{C}$ and 275 - 
$425^{\circ} \mathrm{C}$ ranges respectively (Figure 10). As these fluid inclusions were trapped at various stages of quartz syntectonic crystallization (Figures 7 and S3), fluid entrapment temperatures do represent the temperature interval over which silicification occurred.

Significant scatter in isochores for ODM155 reflect Th variability. Indeed, ODM155 (and to a lesser extent ODM195) exhibits a broad range of homogenization temperatures $\left(\sim 130^{\circ} \mathrm{C}\right)$ at both sample- and grain-scale, associated to homogeneous salinities (4-6 wt.\% eq. $\mathrm{NaCl}$; Figure 8 ). This pattern is typical of post-entrapment deformation of fluid inclusions (Roedder, 1984), and is common in most hydrothermal systems (Delaney et al., 1987; Kelley et al., 1993; Petersen et al., 1998). This result suggests that some inclusion cavities (and therefore fluid density) underwent later re-equilibration during penetrative deformation phases (i.e., slip zones and planes in both samples), slightly modifying P-T isochoric relationships (Diamond et al., 2010; Tarantola et al., 2010; 2012; Vityk \& Bodnar, 1995). In contrast, ODM218 shows a very restricted Th range, thus the isochore fan rather reflects its high variation in salinity $(2-10 \mathrm{wt} . \% \mathrm{NaCl}$, Figure 8$)$ and thus in fluid density.

\subsubsection{Comparison with the temperature of chlorite formation}

The formation temperature of chlorite, which coevally crystallized with quartz in both matrix and clasts during silicification (see 2.2 and Bonnemains et al., 2017), is calculated from chlorite composition (see 4.1.3; Figure 6d; Tables S2 and S4), and is thus an independent estimate of silicification temperature. The large range of chlorite crystallization temperatures $\left(\sim 150-400{ }^{\circ} \mathrm{C}\right.$, Figure 6d) reflects continuous crystallization with quartz during breccia infiltration by hydrothermal fluids and exhumation towards progressively lower P-T conditions in the detachment plane. The temperature range of chlorite formation is coherent with the estimated trapping temperatures for fluid inclusions, intersecting in all cases the isochores at realistic pressures (Figure 10). Interestingly, the chlorite temperature range intersects the isochores at higher pressures, corresponding to lithostatic fluid pressures, for the moderately silicified samples (ODM173 in particular), than for highly silicified samples (ODM218 in particular) for which the median chlorite temperatures intersect the isochores at hydrostatic fluid pressures instead. Near hydrostatic fluid pressures are coherent with the significant fluid amount required to explain pervasive silicification, thus associated with an open system. In contrast, moderately silicified samples submitted to more 
611

612

613

614

615

restricted fluid circulation may instead correspond to a system only transiently open. Silicification is both static and linked to deformation episodes, as demonstrated by successive steps of quartz growth-hydrofracturing-overgrowth (Figures 7 and S3). This complex system witnessed both spatial and temporal fluid pressure variations, bounded by end-member lithostatic to hydrostatic pressures, and linked to variations in rock permeability and fault zone connectivity, likely modulated by both silica sealing and hydrofracturing episodes (Bonnemains et al., 2017).

We thus interpret this silicification as a long-lived, complex process along the detachment plane during exhumation of the hangingwall-derived breccias (Bonnemains et al., 2017), consistent with the large temperature ranges of both chlorite crystallization and fluid entrapment in quartz. We also infer that silicification occurred mostly in the temperature range $\sim 200-400{ }^{\circ} \mathrm{C}$, the highest temperatures corresponding to the highly silicified sample spanning the largest salinity variations (2-10 wt.\% NaCl, ODM218).

\subsection{Fluid compositions and potential fluid sources}

\subsubsection{Insights from fluid inclusion salinity: phase separation}

Fluid inclusions contain an aqueous fluid with salinities generally higher than that of seawater. Fluid inclusions from most samples (ODM155, ODM195, ODM173) present restricted salinity ranges ( $4-6$ wt.\% eq. $\mathrm{NaCl}$ ) corresponding to $\sim 115$ to $170 \%$ of seawater salinity ( $3.2 \mathrm{wt} . \%$ eq. $\mathrm{NaCl}$ ). This range is comparable to ranges of salinity (and $\mathrm{Th}$ ) measured in fluid inclusions (Figure 8a) in rocks associated with hydrothermal fields both of mafic (TAG: Petersen et al., 1998; MARK: Delaney et al., 1987; Saccocia \& Gillis, 1995) and ultramafic nature (Rainbow, Logatchev, Ashadze, Semenov, Irinovskoe; Bortnikov et al., 2011, 2014, 2015; Simonov et al., 2015). Fluid inclusions from the highly silicified sample ODM218 display a large salinity range ( 2.1 to $10 \mathrm{wt} . \%$ eq. $\mathrm{NaCl}$, Figure 8a). At the grain scale, core-to-rim salinity variations are associated to luminescence variations (Figures $7 \mathrm{~b}, \mathrm{~d}, \mathrm{~S} 3 \mathrm{~b}$, e and $8 \mathrm{~b}$ ) but do not show any systematic pattern, rather suggesting that the fault zone witnessed pulses of fluids with variable salinity during deformation.

Salinity in fluid inclusions from subsample ODM218b reaches up to 3 times seawater salinity (i.e., 10 wt.\% equiv. $\mathrm{NaCl}$, Figure 8a). Similar values are also reported for MARK silicified breccias (Delaney et al., 1987). In contrast, many fluid inclusions of subsample ODM218c cluster 
641 at seawater-like salinities, while others in the same sample have salinities below that of seawater 642 (2.1 wt.\% eq. NaCl, Figure 8a), as reported from TAG (Petersen et al., 1998). At least three 643 mechanisms have been proposed to explain salinities of fluid inclusions differing from that of 644 seawater: hydration reactions, chloride retention in secondary minerals, and phase separation:

645 (1) Hydration reactions consume water and, consequently, residual fluids may be enriched in 646 dissolved elements. These reactions increase salinity modestly, with $+15 \%$ for basalt-seawater 647 equilibration at $350{ }^{\circ} \mathrm{C}$ (Wetzel \& Shock, 2000), therefore clearly insufficient to explain the high 648 salinities recorded in sample ODM218b. This process is only efficient at low water-rock ratio 649 conditions and closed systems (Delaney et al., 1987). However, important fluid fluxes are required 650 to attain the observed high levels of silicification (up to 90 vol.\% quartz) in these matrix-supported 651 breccias (see 5.2.2). This precludes that hydration reactions alone may significantly change 652 salinities to values consistent with those observed here (Figure 8a).

653 (2) Chloride storage in transient phases (such as amphiboles, up to $4 \mathrm{wt} . \%$ chlorine; Vanko, 654 1988) can also modulate the salinity of the circulating hydrothermal fluids (Kelley \& Robinson, 655 1990; Kelley et al., 1992). At 13²0’N OCC, hydrothermal amphiboles formed under amphibolite 656 facies conditions (i.e., in clasts, pre-dating silicification) are progressively replaced by chlorite 657 during silicification at lower temperatures (greenschist facies), and could therefore increase fluid 658 salinity. However, the low chloride content of these amphiboles ( $<0.29$ wt.\%; Bonnemains et al., 659 2017) suggests that dissolution of these phases during silicification cannot account by itself for 660 salinities of fluid inclusions within mafic fault breccias, which are three times higher than those of 661 seawater.

662 (3) The only efficient mechanism to generate both high and low salinity fluids is the formation 663 of brine and vapor phases by supercritical phase separation of either seawater or magmatic fluids, 664 as invoked for high-temperature hydrothermal systems (e.g., Alt et al., 2010; Castelain et al., 2014; 665 Delaney et al., 1987; Kelley \& Delaney 1987; Kelley et al., 1992; Vanko, 1988). At the 13²0’N 666 detachment fault, the minimum temperature for supercritical phase separation at the seafloor 667 ( $\sim 3000 \mathrm{~m}, 300$ bars, see 5.1$)$ is $\sim 400{ }^{\circ} \mathrm{C}$ (Figure 11$)$, and would form high salinity brines and a 668 vapor phase. However, we do not have any direct evidence for in-situ phase separation during 669 silicification as we lack fluid inclusions with pure brines (up to $40-50$ wt.\% eq. NaCl), as observed 670 in diabases (Kelley \& Delaney, 1987) or trondhjemite (Castelain et al., 2014; Figure 8a), or 
671 inclusions with pure vapor phase (vapor to total volume of 0.1-0.5 in our study). This suggests that 672 phase separation occurred earlier, at deeper levels. Vapor and brine were likely segregated and 673 migrated upwards separately, similarly to the two-stage model proposed by Delaney et al. (1987) 674 for the MARK hydrothermal field. The wide range of salinities (i.e., from lower- to three times 675 higher-than-seawater) reported in $13^{\circ} 20^{\prime} \mathrm{N}$ silicified fault rocks may be accounted for by either re676 homogenization of variable amounts of brines and vapor phases once released in the detachment 677 fault (in the one-phase field, Figure 11), or their mixing with fluids of different salinity, prior to 678 fluid entrapment in quartz.

679 Although we have no direct constraints, we hypothesize that phase separation may have occurred in the brecciation zone or its immediate vicinity. Indeed, most of the breccia clasts from $13^{\circ} 20^{\prime} \mathrm{N}$ fault zone are originally diabase, suggesting that they were initially part of the

682 hangingwall dyke complex adjacent to the detachment fault (see 2.2 and 5.1 and Bonnemains et al., 2017). With a fully developed amphibolite facies paragenesis (hornblende + labradorite), these rocks experienced hydrothermal alteration at temperatures higher than $500{ }^{\circ} \mathrm{C}$ (see review in Alt, 1995), likely at the base of the upper crust (root of the dyke complex), therefore acting as a reaction zone. Fluid pressures in this reaction zone may be between hydrostatic and lithostatic, even close to hydrostatic for high fluid fluxes. Figure 11 shows that cold seawater infiltrating the hangingwall towards the base of the crust would undergo phase separation between $440{ }^{\circ} \mathrm{C}$ and $570{ }^{\circ} \mathrm{C}$, depending on the fluid pressure gradient. It is thus plausible that phase separation occurred in the reaction zone where brecciation is inferred to take place (e.g., Bonnemains et al., 2017). Diabase brecciation along the detachment fault zone may even enhance phase separation, promoting sudden fluid pressure drops leading to the crossing of the liquid-vapor curve (Figure 11).

\subsubsection{Insights from bulk-rock and chlorite compositions: a mafic-rock derived fluid}

Textural and mineralogical observations, coupled to bulk-rock analyses, document that diabase breccias underwent variable silicification during exhumation within the detachment zone (see 4.1.1), reaching up to $\sim 90$ vol.\% of quartz in matrix-supported breccias (Figure 5; Tables 2 and S1). Such degrees of silicification require both circulation of a silica-rich fluid and high fluid-rock required for basalt replacement by quartz-chlorite assemblages at $300{ }^{\circ} \mathrm{C}$ (Mottl, 1983). Elevated 
fluid fluxes are also supported by the enhanced leaching of alkalis and calcium (Figures 5a and S1a-b) from diabase clasts with increasing silicification (Bach et al., 2013; Cann, 1969).

Chlorite crystallization in both clasts and matrix is associated to silicification, as showed by chlorite and quartz co-crystallization textures, increasing amount of chlorite with silicification, and similar chlorite composition in both clasts and matrix (Figure 6a). The decrease of bulk-rock and chlorite $\mathrm{Mg \#}$ with increasing silicification (Figures $5 \mathrm{~b}$ and $6 \mathrm{~b}$ ), correlated to pyrite crystallization in the highly silicified breccias, suggests interaction with iron-rich fluids. The association iron-rich chlorites, quartz and pyrite has been observed in silicified oceanic hydrothermal breccias associated with mafic-rock hosted vents such as TAG (Alt et al., 1985; Honnorez et al., 1998; Humphris et al., 1998) or at the MARK area (Delaney et al., 1987; Saccocia \& Gillis, 1995). For Saccocia and Gillis (1995), these minerals result from interactions with high salinity, silica- and iron-rich fluids, depleted in $\mathrm{H}_{2} \mathrm{~S}$. This is in agreement with the high salinity (Figure 8) and low $\mathrm{H}_{2} \mathrm{~S}$ content (only recorded in 4 fluid inclusions from ODM218, Figure 9a) in our fluid inclusions. Hence, almost all $\mathrm{H}_{2} \mathrm{~S}$ was likely stored into pyrite, leading to iron-enriched fluids from which Fe-rich chlorites crystallized (type I breccias from Saccocia \& Gillis, 1995). A low $\mathrm{H}_{2} \mathrm{~S}$ content in fluids is also consistent with the small amount of metallic trace elements recorded in our fluid inclusions (i.e., diluted fluids, see 4.2.3). Such fluid composition is characteristic of highly evolved hydrothermal fluids sampled in upflow zones of hydrothermal cells, and recording mafic rock-hosted reaction zones (Bach et al., 2013; Saccocia \& Gillis, 1995).

The significant amounts of silica precipitated in detachment fault breccias also suggest the leaching of a deep mafic source. Indeed, high-temperature hydrothermal fluids from the reaction zone at the base of the mafic upper crust may be quartz-saturated (or close to) according to Wetzel and Shock (2000; 20 mmolal of aqueous silica at $400^{\circ} \mathrm{C}$ for seawater-basalt equilibrium). This is in agreement with fluid composition from basalt-hosted hydrothermal vents at $>300{ }^{\circ} \mathrm{C}$ (Fouquet et al., 2010; Schmidt et al., 2011; McDermott et al., 2018). Fluids circulating upwards along the detachment fault zone may witness both a significant temperature reduction (to $200-300{ }^{\circ} \mathrm{C}$ ) and pressure drops, promoting fluid supersaturation and quartz precipitation. On the contrary, hydrothermal fluids equilibrated with peridotite should be largely undersaturated with respect to quartz (0.5 mmolal of aqueous silica at $400^{\circ}$, Wetzel \& Shock, 2000), and vent fluids from ultramafic-hosted hydrothermal systems generally record $6-8 \mathrm{mmol} / \mathrm{L}$ of aqueous silica (Fouquet, 2010). Under these conditions, a temperature drop of $200^{\circ} \mathrm{C}$ will not be sufficient to trigger quartz 
732

733

734

735

736

737

738

739

740

741

742

743

744

745

746

747

748

749

750

751

752

753

754

755

756

757

758

759

760

3

crystallization. Hence, silica may only be provided by fluids reacting with mafic rocks. Moreover, the high amount of silica crystallized in the breccia matrix (up to $90 \mathrm{vol} \%$ of quartz) requires circulation of extremely Si-rich fluids: phase separation and brine formation in the reaction zone may have enhanced aqueous silica concentration, as quartz solubility is about one order of magnitude higher in $\mathrm{NaCl}$-rich brines than in pure $\mathrm{H}_{2} \mathrm{O}$ ( Scheuermann et al., 2018; Schmidt et al., 2011; Steele-MacInnis et al., 2011), promoting efficient silica transport towards the upflow zone along the detachment fault.

Therefore, significant amounts of highly evolved hydrothermal fluids from a reaction zone at the base of the hangingwall dyke complex flowed up along the detachment fault zone, transporting leached aqueous silica. This syntectonic circulation resulted in intense and pervasive silicification of mafic detachment fault breccias (with crystallization of Fe-rich chlorite and pyrite).

\subsubsection{Insights from fluid inclusion gas content: mix with an ultramafic-derived fluid}

While most fluid inclusions are purely aqueous $\left(\mathrm{H}_{2} \mathrm{O}-\mathrm{NaCl}\right)$, some contain small amounts of $\mathrm{H}_{2}$, $\mathrm{CO}_{2}, \mathrm{CH}_{4}$, and minor amounts of $\mathrm{H}_{2} \mathrm{~S}$ (i.e., ODM218b and ODM218c; Figure 9; Table 3) in addition to dominant $\mathrm{H}_{2} \mathrm{O}\left(\mathrm{H}_{2} \mathrm{O}-\mathrm{NaCl}-\mathrm{H}_{2} \pm \mathrm{CO}_{2} \pm \mathrm{CH}_{4} \pm \mathrm{H}_{2} \mathrm{~S}\right)$. Seawater phase separation cannot produce all these gases, and other fluid sources are required. Among these minor gases, $\mathrm{H}_{2}$ is by far the most abundant in the inclusions (Figure 9; Table 3). $\mathrm{H}_{2}$ is likely produced during serpentinization reactions by oxidation of the iron contained in olivine, reactions that preferentially occur between 200 and $350{ }^{\circ} \mathrm{C}$ (Martin \& Fyfe, 1970; McCollom \& Bach, 2009; Seyfried et al., 2007). At high temperatures $\left(>400{ }^{\circ} \mathrm{C}\right), \mathrm{H}_{2}$ may also be produced in mafic rocks by pyroxene alteration (Allen \& Seyfried, 2003; Foustoukos \& Seyfried, 2005). $\mathrm{CO}_{2}$ can be either linked to seawater, or to a magmatic source enriching nearby fluids. $\mathrm{CH}_{4}$ likely results from $\mathrm{CO}_{2}$-rich fluids reacting with $\mathrm{H}_{2}$. This reaction may occur either during serpentinization, from hydrothermal circulation in ultramafic rocks enriching fluids in both hydrogen and methane (Berndt et al., 1996; Boulart et al., 2013; Charlou et al., 1998, 2002; Holm \& Charlou, 2001; Monnin et al., 2014; Wetzel \& Shock, 2000), in $\mathrm{H}_{2}$-rich fluid inclusions hosted in footwall magmatic rocks (e.g., Klein et al., 2019; McDermott et al., 2015), or at a later time (e.g., during transport), but in any case, prior to fluid entrapment during silicification. 
To discriminate the origin of fluids that circulated along the detachment fault zone, we compare the ratios of $\mathrm{H}_{2}, \mathrm{CO}_{2}, \mathrm{CH}_{4}, \mathrm{H}_{2} \mathrm{~S}$ in our fluid inclusions to those analyzed in vent fluids (from MAR mainly). While few inclusions present a $\mathrm{CO}_{2}$-dominant gas content comparable to basalt-hosted vent fluids, most of these inclusions show high $\mathrm{H}_{2} / \mathrm{CO}_{2}$ and $\mathrm{H}_{2} / \mathrm{CH}_{4}$ ratios (Figure $9 \mathrm{a}$ ) and very low $\mathrm{H}_{2} \mathrm{~S} / \mathrm{H}_{2}$ ratios (Figure 9b), signatures typical of ultramafic-hosted vent fluids (e.g., Rainbow, Logatchev, Semenov, Irinovskoe; Destringeville et al., 2015; Fouquet et al., 2010; Schmidt et al., 2011), and of hydrothermal alteration of ultramafic rocks (i.e., serpentinization $<400{ }^{\circ} \mathrm{C}$, Wetzel \& Shock, 2000). However, fluids from the Piccard vents at the ultraslow spreading Cayman ridge show anomalously high $\mathrm{H}_{2}$ contents and $\mathrm{H}_{2} / \mathrm{H}_{2} \mathrm{~S}$ ratios, for mafic-rock-derived vents (McDermott et al., 2018). These fluids are interpreted as resulting from basalt alteration in a reaction zone at very high temperature $\left(>500^{\circ} \mathrm{C}\right)$ and high fluid/rock ratios $(\mathrm{McDermott}$ et al., 2018; Scheuermann et al., 2018). This suggests that the high $\mathrm{H}_{2} / \mathrm{H}_{2} \mathrm{~S}$ ratios analyzed in our fluid inclusions could derive from the hangingwall reaction zone. Lacking experimental data on basalt alteration at $>500^{\circ} \mathrm{C}$, reactions able to release such high $\mathrm{H}_{2}$ amounts remain unknow. The reaction invoked by Scheuermann et al. (2020), of amphibole destabilization to magnetite and quartz, is clearly incompatible with our rocks, as hornblende is fresh in the least altered clasts (Bonnemains et al., 2017), and no magnetite (neither quartz) was observed. Moreover, $\mathrm{H}_{2} / \mathrm{H}_{2} \mathrm{~S}$ ratios in Piccard vent fluids remain lower than those measured in most of our fluid inclusions (Figure 9b), although there is no reason for different partitioning of $\mathrm{H}_{2}$ and $\mathrm{H}_{2} \mathrm{~S}$ between brines and vapor phases after phase separation (McDermott et al., 2018; Scheuermann et al., 2020). Therefore, $\mathrm{H}_{2}$ production in the reaction zone seems to be possible, but may not account for the elevated $\mathrm{H}_{2} / \mathrm{H}_{2} \mathrm{~S}$ ratios analyzed in our fluid inclusions, which are best explained by $\mathrm{H}_{2}$ derived from ultramafic-rock serpentinization. Contribution of ultramafic-derived fluids is further supported by slight $\mathrm{Cr}$ and $\mathrm{Ni}$ enrichments of both sample ODM218b (Figure 5c) and some chlorites from highly silicified mafic breccias (Tables S2 and S3; Angiboust et al., 2014; Boutoux et al., 2014; Locatelli et al., 2019 ; Spandler et al., 2011).

While the hangingwall sampled by the fault zone likely extends only to the base of the dyke complex, the footwall below the fault zone and deep sections of the hangingwall likely contain mantle peridotites that witnessed fluid circulation. This is demonstrated by the occurrence of mixed breccias containing altered ultramafic clasts (Bonnemains et al., 2017), and the outcropping of 
792

793

794

795

796

797

798

799

800

801

802

803

804

805

806

807

808

809

810

811

812

813

814

815

816

817

818

819

820

821

exhumation, peridotites likely interacted with seawater-derived fluids, and progressively serpentinized. Fluids may have been subsequently channelized into and along the detachment fault zone. Mixing of such seawater-salinity fluids with silica-rich brines and vapor phases (prior to entrapment) could account for the wide salinity range observed in trapped fluids from the silicified breccias (Figure 8). This contribution of serpentinization fluids must remain limited nonetheless, as the absolute gas amounts trapped in fluid inclusions are extremely low. We also note that two thirds of the analyzed fluid inclusions from ODM218 have a gas signature very close to that analyzed for Irinovskoe vent fluids (Figure 9a), and that present-day fluid circulation within the footwall may record similar fluid-peridotite reactions at depth, even though these fluids do not exploit the detachment fault as a flow channel.

\subsection{Detachment faulting, potential heat sources at the ridge axis and scenario for fluid pathways}

Our results suggest that silicification was linked to flow along the detachment fault zone of silica-rich brines and minor vapor phases likely mainly formed in the hangingwall reaction zone (Figure 12a). Such a reaction zone at the base of the upper crust requires a heat source, such as a magma chamber at deeper levels and nearby the fault, or an along-axis dyke propagation (Bonnemains et al., 2017; MacLeod et al., 2009). The conceptual model in Figure 12a builds on the detachment fault zone structure suggested by Bonnemains et al. (2017) and Parnell-Turner et al. (2018). This model includes a) the incorporation of mafic clasts from the hangingwall upper crust into the detachment fault zone, from its base to the near-surface (brown stars in Figure 12), b) a thickening of the fault zone during exhumation, and c) an anastomosed fault zone mixing footwall-derived ultramafic material with dominant mafic material from the hangingwall. This model is also consistent with recent 3D seismic experiments revealing elevated seismic velocities at the footwall, both along the exposed detachment fault, and below its continuation eastwards below the rift valley floor (Simão et al., 2020). Elevated footwall seismic velocities are consistent with a lithosphere composed of lower crust and upper mantle rocks, juxtaposed to mafic rocks across the detachment (Simão et al., 2020).

As illustrated in Figure 12b, we propose that seawater percolates downwards through the hangingwall crust, reaching a reaction zone at temperatures $>500{ }^{\circ} \mathrm{C}$, at or near the axial zone. 
822 High-temperature fluids circulating into the reaction zone may hydrothermally alter surrounding 823 mafic rocks, while releasing aqueous silica and potentially small amounts of $\mathrm{H}_{2} \mathrm{~S}$ in the fluid phase 824 (e.g., Bach et al., 2013; Wetzel \& Shock, 2000). At these P-T conditions, phase separation occurs 825 and forms high-salinity brines and low-salinity vapor phases. The small number of inclusions 826 recording lower-than-seawater salinity (Figure 8a) suggests that only limited amounts of vapor 827 reached and circulated within the detachment zone, while most of these low-density vapor phases 828 may have migrated upwards through the hangingwall crust (Figures 11 and 12). Denser, less 829 buoyant brines may be stored at depth in crustal porosity, within diabase units (Fontaine \& 830 Wilcock, 2006; Fontaine et al., 2007). Brines may be released into the detachment fault zone upon 831 diabase brecciation, together with minor amounts of vapor phases, locally produced $\mathrm{H}_{2} \mathrm{~S}$, and 832 potentially $\mathrm{CO}_{2}$ either transported by seawater or exsolved from the magma lens. Diabase 833 brecciation may enhance phase separation by causing sudden and local fluid pressure drops (Figure 834 11). In turn, fluid phase separation may also promote local overpressures that may favor brecciation 835 along the fault (André-Mayer et al., 2002; Bertelli \& Baker, 2010), with possible links to seismicity 836 along the detachment.

837 Varying gas content and wide salinity ranges of trapped fluids point to a complex and dynamic 838 system. During silicification of the fault zone, upwelling silica-rich brines and minor vapors mixed 839 in variable amounts with $\mathrm{H}_{2}\left( \pm \mathrm{CH}_{4}\right)$-rich fluids derived from serpentinization of ultramafic material 840 from the footwall (Figures 11 and 12; Andreani et al., 2014; McCaig et al., 2010; McCaig \& Harris, 841 2012). These fluids homogenized as a single fluid phase before trapping (one-phase fluid field, 842 Figure 11). Fluid fluxes from these different sources were likely variable both in time and within 843 the fault zone, resulting in strong variability of both gas content and salinity of fluid inclusions 844 (Figures 8 and 9). Significant variations of inclusion fluid composition at quartz grain scale 845 (Figures 7b, d, S3b, e and 8b) clearly indicate that the fluids circulating along the detachment were 846 inherently heterogeneous at small spatial scales and short temporal scales. Yet there is no evidence 847 for any systematic long-term evolution in fluid sources or fluid mixing processes during 848 silicification (i.e., similarity in primary and secondary fluid inclusion salinity ranges). Moreover, 849 the wide distribution of samples along axis and the pervasively silicified fault zone also indicate 850 that this heterogeneous flow was maintained over long-periods of time, and was sampled by the 851 detachment fault along most of its along-axis length. 
All these fluids were preferentially channelized within the permeable fault zone, and silica precipitation was likely triggered by a combination of temperature decrease, pressure drops, and mixing of silica-rich brines with less-salted fluids. Both chlorite and fluid inclusion temperatures (Figures 10 and 11) are lower than those measured at the base of the dyke complex elsewhere (Hole under greenschist facies conditions. Upflow silica-rich brines were likely cooled either continuously or episodically, during transient circulation in a complex, anastomosing fault zone, and coeval with deformation leading to quartz fracturing-sealing episodes (i.e., fluid pressure varying between hydrostatic and lithostatic; Figures 7 and 10), but also by fluid mixing with cooler fluids from the footwall serpentinization and potentially seawater percolating from the seafloor.

\subsection{Fluids trapped in detachment fault rocks vs. seafloor hydrothermal venting}

Models of fluid flow and detachment faulting often assume a permeable fault zone efficiently channeling fluids to the seafloor or the shallow crust (e.g., Andersen et al., 2014; McCaig \& Harris, 2012; Tao et al., 2020). In these models, fluid flow through the detachment fault feeds hydrothermal systems found both at the footwall (e.g., Logatchev; Andersen et al., 2014; Longqi: Tao et al., 2020) and hangingwall (TAG; McCaig \& Harris, 2012). The heat source animating this circulation is often located in the upper mantle, at the base of the detachment microseismicity.

Our data and results from the $13^{\circ} 20^{\prime} \mathrm{N}$ detachment are not consistent with these deep-rooted hydrothermal systems along detachment fault zones. First, the present-day Irinovskoe hydrothermal site is located on the striated surface. As the detachment fault emerges at $\angle 20^{\circ}$ at the 873 (e.g., Escartín et al., 2017; Parnell-Turner et al., 2018), no plausible mechanism can channel fluids 874 from the active detachment fault zone below the rift valley floor (below the hangingwall cutoff) to 875 the Irinovskoe site, over a horizontal distance of $\sim 2 \mathrm{~km}$. The footwall also displays both a high876 velocity seismic anomaly underlying Irinovskoe, restricted to the shallower $2 \mathrm{~km}$, and a broad low velocity zone at 7-10 km depth (Simão et al., 2020). Owing to seismic resolution limitations, the presence of magma chambers or heat sources of sizes below the seismic resolution (1 to $3 \mathrm{~km}$ in 879 size, depending on the depth) cannot be excluded. We propose that the fluid circulation system 880 underlying Irinovskoe is unrelated to the active detachment, and instead is fully hosted within the footwall, probably reaching depths $>2 \mathrm{~km}$. While we lack direct seismic evidence here, this model 
is similar to that of Rainbow, a hydrothermal field at the top of a detachment massif that is underlain by seismic reflectors identified as active and fossil magma chambers at depths $>3 \mathrm{~km}$ (Canales et al., 2017; Dunn et al., 2017).

Silicified fault rocks are distributed throughout the detachment, displaying similar fluid compositions in quartz inclusions. This observation points to a flow organization along the detachment that has not been recognized before. Geological observations demonstrate that syntectonic silicification and associated fluid circulation occurred along the whole length (alongaxis, Figure 1) of the active detachment, and that it operated continuously over time (across-axis; Bonnemains et al., 2017). Fluid inclusions further indicate that similar fluid sources (similar primary and secondary inclusions) mixed within the detachment plane (see 5.2.1 and Figure 8a). This type of distributed and pervasive hydrothermal circulation, extending laterally over several $\mathrm{km}$ and sustained over long periods of time, contrasts with the extremely localized outflow observed at the seafloor over relatively small surfaces (spatial scales of a few hundreds of $m$ at most). Assuming that similar fluid circulation linked to deformation operates along the presentday, active detachment fault and at depth, this would require an extreme fluid flow localization on a short vertical distance $(\sim 2 \mathrm{~km})$, in addition to implausible fluid transport within the footwall.

In our preferred interpretation, the fault zone and the fluids within cool down efficiently during exhumation at the shallower levels of the fault. This cooling can effectively suppress convection and any active circulation in shallow parts of the system, precluding discharge of high-temperature fluids at the seafloor. We suggest that the observed present-day hydrothermal activity observed on the surface of footwall of detachments (e.g., Rainbow, Semenov, Irinovskoe, Mount Den, Mount Fuji) is most likely due to heat sources underlying these sites and located within the detachment footwall, rather than fluids steered along the detachment fault and with significant lateral flow. The hydrothermal system that we document here may be indeed active at depth at $13^{\circ} 20^{\prime} \mathrm{N}$, and be widespread at other systems. Indeed, many active detachments rooting near-axis (e.g., TAG, Dragon Horn) may be active in close proximity to nearby heat sources (melt lenses or dykes propagating along-axis), sampling fluids from the associated reaction zone at depth. As these systems may be restricted to deep lithospheric levels $(>1 \mathrm{~km})$ and lack a seafloor expression, they may only be identifiable studying in situ detachment fault rocks. 


\section{Conclusions}

The $13^{\circ} 20^{\prime} \mathrm{N}$ detachment fault zone displays pervasive, syntectonic silicification of fault breccia that is originally mostly of mafic origin (diabase). Quartz crystals in breccia matrix and clasts preserve fluid inclusions. Their analyses, coupled to both bulk-rock and chlorite geochemical compositions, allow us to constrain hydrothermal fluid flow during deformation, and propose a conceptual model of detachment deformation and fluid flow.

First, we document the mixing of two fluid sources based on fluid inclusion salinity and gas content: 1) primarily brines and minor amounts of vapor phases resulting from phase separation at high temperature $\left(\mathrm{T}>410^{\circ} \mathrm{C}\right)$, and likely occurring in the hangingwall reaction zone at the base of the dyke complex; and 2) minor amounts of fluids that interacted with ultramafic rocks, likely recording serpentinization reactions at temperatures of $200-350{ }^{\circ} \mathrm{C}$, associated with $\mathrm{H}_{2}\left(\right.$ and $\left.\mathrm{CH}_{4}\right)$ production. The lack of correlation between salinity and gas content, as well as quartz grain-scale variations of fluid composition, suggests syntectonic mixing in variable proportions of compositionally heterogeneous flows at small spatial and short temporal scales.

The hydrothermal circulation we document along the detachment fault zone reaches the base of the hangingwall dyke complex, i.e., $2 \mathrm{~km}$ depth, as constrained by seismic refraction data. Fault zone rocks are brecciated and incorporated into the detachment, together with the silica-rich brines emanating from a nearby reaction zone. A significant temperature drop is recorded by chlorite thermometry, from amphibolite facies $\left(\sim 500^{\circ} \mathrm{C}\right)$ to quartz/chlorite equilibrium temperatures as low as $\sim 200^{\circ} \mathrm{C}$. This temperature drop likely occurs both over small spatial distances and over short periods of time, with transients, promoting syntectonic silica precipitation in the fault zone. The hydrothermal circulation documented here is decoupled from present day hydrothermal activity at the seafloor. We suggest that detachment-related hydrothermal flow, which is widespread, is likely hosted within the footwall of detachments, passively cross-cuts inactive detachment faults, and is unrelated to the active detachment fault operating at depth.

Acknowledgements - The authors warmly acknowledge M-C. Caumon for her help with Raman Spectroscopy on fluid inclusions at GeoRessources Nancy, O. Boudouma and M. Fialin for their assistance with SEM-cathodoluminescence and EPMA respectively, M. Quintin and E. Delairis for thin and thick sections preparation respectively. We thank B. Dubacq and J. Touret for fruitful 
942 discussions on chlorite analysis and fluid inclusions, respectively. Two anonymous reviewers are

943 acknowledged for their critical remarks, and W. Berh and Associate Editor for editorial handling. 944 This work was funded by INSU Tellus-SYSTER program (ODEFLUIN). Data were acquired 945 during the ODEMAR cruise (https://doi.org/10.17600/13030070) and we thank the extraordinary 946 work of the crew, engineers, and officers that led to an extremely successful cruise. Bathymetry 947 (shipboard and AUV) data are publicly available through www.seanoe.org 948 (https://doi.org/10.17882/48324, https://doi.org/10.17882/48335), and samples presented here are 949 available for further studies through the Marine Rock Repository at IPGP (see lithotheque.ipgp.fr) 950 or contacting JE. 


\section{References}

Allen, D.E. \& Seyfried, W.E. (2003) Compositional controls on vent fluids from ultramatichosted hydrothermal systems at mid-ocean ridges: An experimental study at 400 degrees C, 500 bars. Geochimica Et Cosmochimica Acta, 67, 1531-1542. https://doi.org/10.1016/S0016-7037(02)01173-0

Alt, C. J. (1995). Subseafloor processes in mid-ocean ridge hydrothermal systems. In S. E. Humphris et al. (Eds.), Seafloor Hydrothermal Systems: Physical, Chemical, Bio- logical, and Geological Interactions, Geophys. Monogr. Ser. (Vol.91, pp. 85-114). Washington, DC: AGU, https://doi.org/10.1029/GM091p0085.

Alt, J.C., Laverne, C., Coggon, R.M., Teagle, D.A.H., Banerjee, N.R., Morgan, S., et al. (2010). Subsurface structure of a submarine hydrothermal system in ocean crust formed at the East Pacific Rise, ODP/IODP Site 1256. Geochemistry, Geophysics, Geosystems, 11(10), p. 1-28. https://doi.org/10.1029/2010GC003144

Alt, J.C., Laverne, C., \& Muehlenbachs, K. (1985). Alteration of the upper oceanic crust: mineralogy and processes in Deep Sea Drilling Project Hole 504B, Leg 83. In R.N. Anderson, J. Honnorez, K. Becker, et al., Init. Repts. DSDP, 83: Washington (US Govt. Printing Office), 217-247

Andersen, C., Rupke, L., Hasenclever, J., Grevemeyer, I., \& Petersen, S. (2014). Fault geometry and permeability contrast control vent temperatures at the Logatchev 1 hydrothermal field, Mid-Atlantic Ridge. Geology, 43(1), 51-54. https://doi.org/10.1130/G36113.1

André-Mayer, A-S., Leroy, J.L., Bailly, L., Chauvet, A., Marcoux, E., Grancea, L., et al. (2002). Boiling and vertical mineralization zoning: a case study from the Apacheta low-sulfidation epithermal gold-silver deposit, southern Peru. Mineralium Deposita, 37, 452-464. https://doi.org/10.1007/s00126-001-0247-2

Andreani, M., Escartin, J., Delacour, A., Ildefonse, B., Godard, M., Dyment, J., Fallick, A.E., \& Fouquet, Y. (2014). Tectonic structure, lithology, and hydrothermal signature of the Rainbow massif (Mid-Atlantic Ridge 36 $14^{\prime} \mathrm{N}$ ). Geochemistry, Geophysics, Geosystems, 15, 35433571. https://doi.org/10.1002/2014GC005269

Angiboust, S., Pettke, T., De Hoog, J.C.M., Caron, B., \& Oncken, O. (2014). Channelized Fluid Flow and Eclogite-facies Metasomatism along the Subduction Shear Zone. J. Petrol. 55, 883-916. https://doi.org/10.1093/petrology/egu010 
Bach, W., Jons, N., \& Klein, F. (2013). Metasomatism within the oceanic crust. In D. E. Harlov \& H. Austrheim (Eds.). Metasomatism and the chemical transformation of rock. Lecture notes in Earth System Sciences. Springer, Berlin, Heidelberg. https://doi.org/10.1007/978-3-64228394-9_8

Berndt, M.E., Allen, D.E. \& Seyfried, W.E. (1996) Reduction of CO2 during serpentinization of olivine at 300 degrees $C$ and 500 bar (vol 24, pg 351, 1996). Geology, 24, 671-671. https://doi.org/10.1130/0091-7613(1996)024<0351:ROCDSO>2.3.CO;2

Bertelli, M. \& Baker, T. (2010). A fluid inclusion study of the Suicide Ridge Breccia Pipe, Cloncurry district, Australia: implication for breccia genesis and IOCG mineralization. Precambrian Research, 179 (1-4), 69-87. https://doi.org/10.1016/j.precamres2010.02.016

Bodnar, R. J. (1993). Revised equation and table for determining the freezing point depression of $\mathrm{H}_{2} \mathrm{O}-\mathrm{NaCl}$ solutions. Geochim. Cosmochim. Acta 57, 683-684.

Boiron, M.C., Essarraj, S., Sellier, E., Cathelineau, M., Lespinasse, M., Poty, B. (1992). Identification of fluid inclusions in relation to their host microstructural domains in quartz by cathodoluminescence. Geochim. Cosmochim Acta 56, 175-185.

Bonnemains, D., Escartín, J., Mével, C., Andreani, M., \& Verlaguet, A. (2017). Pervasive silicification and hanging wall overplating along the $13^{\circ} 20^{\prime} \mathrm{N}$ oceanic detachment fault (MidAtlantic Ridge): Geochemistry, Geophysics, Geosystems, 18(6), 2028-2053. https://doi.org/10.1002/2017GC006846

Bortnikov, N.S., Simonov, V.A., Amplieva, E.E., \& Borovikov, A.A. (2014). Anomalously high concentrations of metals in fluid of the Semenov Modern Hydrothermal System (MidAtlantic Ridge, $\left.13^{\circ} 31^{\prime} \mathrm{N}\right)$ : LA-ICP-MS study of fluid inclusions in minerals. Doklady Earth Sciences, 456(2), 714-719. https://doi.org/10.1134/S1028334X14060221

Bortnikov, N.S., Simonov, V.A., Amplieva, E.E., Stavrova, O.O., \& Fouquet, Y. (2011). The physicochemical conditions of hydrothermal ore-forming systems of "black smokers" associated with mantle ultrabasites in the Central Atlantic region. Russian Geology and Geophysics, 52(11), 1412-1420. https://doi.org/10.1016/j.rgg.2011.10.010

Bortnikov, N.S., Simonov, V.A., Borovikov, A.A., Bel, V.E., Amplieva, E.E., Kotlyarov, A. V, and Bryanskiy, N. V (2015). The metalliferous fluid of the hydrothermal sulfide system associated with the oceanic core complex $13^{\circ} 20^{\prime} \mathrm{N}$, The Mid-Atlantic Ridge (LA-ICP-MS and fluid inclusions), in Oceanic Core Complexes and Hydrothermalism, p. 80-83 
1013

1014

1015

1016

1017

1018

1019

1020

1021

1022

1023

1024

1025

1026

1027

1028

1029

1030

1031

1032

1033

1034

1035

1036

1037

1038

1039

1040

1041

1042

Boschi, C., Früh-Green, G., Delacour, A., Karson, J., \& Kelley, D.S. (2006). Mass transfer and fluid flow during detachment faulting and development of an oceanic core complex, Atlantic Massif (MAR 30N). Geochemistry, Geophysics, Geosystems, 7(1), Q01004, https://doi.org/10.1029/2005GC001074

Boulart, C., Chavagnac, V., Monnin, C., Delacour, A., Ceuleneer, G., \& Hoareau, G. (2013). Differences in gas venting from ultramafic-hosted warm springs: the example of Oman and Ligurian Ophiolites. Ofioliti, 38(2), 142-156. https://doi:10.4454/ofioliti.v38i2.423.

Bourdelle, F., Parra, T., Chopin, C., \& Beyssac, O. (2013). A new chlorite geothermometer for diagenetic to low-grade metamorphic conditions. Contributions to Mineralogy and Petrology, 165(4), 723-735. https://doi.org/10.1007/s00410-012-0832-7

Bourdelle, F. \& M. Cathelineau (2015). Low-temperature chlorite geothermometry: a graphical representation based on a T-R ${ }^{2+}-$ Si diagram. European Journal of Mineralogy, 27(5), 617626. https://doi.org/10.1127/ejm/2015/0027-2467

Boutoux, A., Verlaguet, A., Bellahsen, N., Lacombe, O., Villemant, B., Caron, B., Martin, E., Assayag, N., \& Cartigny, P. (2014) Fluid systems above basement shear zones during inversion of pre-orogenic sedimentary basins (External Crystalline Massifs, Western Alps). Lithos, 206-207, 435-453. https://doi.org/10.1016/j.lithos.2014.07.005

Buck, W.R., Lavier, L.L., and Poliakov, A.N.B., 2005, Modes of faulting at mid-ocean ridges: Nature, v. 434, p. 719-723

Canales, J.P., Dunn, R.A., Arai, R., \& Sohn, R.A. (2017). Seismic imaging of magma sills beneath an ultramafic-hosted hydrothermal system. Geology, 45(5), 451-454. https://doi.org/10.1130/G38795.1

Cann, J.R. (1969). Spilites from the Carlsberg Ridge, Indian Ocean. Journal of Petrology, 10, $1-$ 19

Cannat, M., Sauter, D., Mendel, V., Ruellan, E., Okino, K., Escartin, J., Combier, V., \& Baala, M. (2006). Modes of seafloor generation at a melt-poor ultraslow-spreading ridge. Geology, 34(7), 605-608. https://doi.org/10.1130/G22486.1

Carignan, J., Hild, P., Mevelle, G., Morel, J., \& Yeghicheyan, D. (2001). Routine analyses of trace elements in geological samples using flow injection and low pressure on-line liquid chromatography coupled to ICP-MS: a study of geochemical reference materials BR, DR-N, 
UB-N, AN-G and GH. Geostandards and Geoanalytical Research, 25(2-3), 187-198. https://doi.org/10.1111/j.1751-908X.2001.tb00595.X

Castelain, T., McCaig, A.M., \& Cliff, R.A. (2014). Fluid evolution in an Oceanic Core Complex: A fluid inclusion study from IODP hole U1309 D-Atlantis Massif, 30 N, Mid-Atlantic Ridge. Geochemistry, Geophysics, Geosystems, 15(4), 1193-1214. https://doi.org/10.1002/2013GC004975

Charlou, J.L., Fouquet, Y., Bougault, H., Donval, J.P., Etoubleau, J., Jean-Baptiste, P., Dapoigny, A., Appriou, P., \& Rona, P.A. (1998). Intense $\mathrm{CH}_{4}$ plumes generated by serpentinization of ultramafic rocks at the intersection of the $15^{\circ} 20^{\prime} \mathrm{N}$ fracture zone and the Mid-Atlantic Ridge. Geochim. Cosmochim. Acta 62, 2323 - 2333. https://doi.org/10.1016/S0016-7037(98)001380

Charlou, J.J., Donval, J.P., Fouquet, Y., Jean Baptiste, P., \& Holm, N. (2002). Geochemistry of high $\mathrm{H}_{2}$ and $\mathrm{CH}_{4}$ vent fluids issuing from ultramafic rocks at the Rainbow hydrothermal field (36²'N, MAR). Chemical Geology, 191, 345-359. https://doi.org/10.1016/S00092541(02)00134-1

Cherkashev, G.A., Ivanov, V.N., Lazareva, L.I., Rozhdestvenskaya, I.I., Samovarov, M.L., Poroshina, I.M., Sergeev, M.B., Stepanova, T. V, \&c Dobretsova, I.G. (2013). Massive sulfide ores of the northern equatorial Mid Atlantic Ridge. Oceanology, 53(5), 607-619. https://doi.org/10.1134/S0001437013050032

Coumou, D., Driesner, T., Geiger, S., Paluszny, A., \& Heinrich, C. A. (2009). High-resolution three-dimensional simulations of mid-ocean ridge hydrothermal systems. J. Geophys. Res., 114, B07104, https://doi.org/10.1029/2008JB006121

Delaney, J.R., Mogk, D.W., \& Mottl, M. (1987). Quartz-cemented breccias from the Mid-Atlantic Ridge: Samples of a high-salinity hydrothermal upflow zone. Journal of Geophysical Research, 92(B9), 9175. https://doi.org/10.1029/JB092iB09p09175

deMartin, B.J., Sohn, R.A., Canales, J.P., \& Humphris, S.E. (2007). Kinematics and geometry of active detachment faulting beneath the Trans-Atlantic Geotraverse (TAG) hydrothermal field on the Mid-Atlantic Ridge. Geology, 35(8), 711-714. https://doi.org/10.1130/G23718A.1

Destrigneville, C., Chavagnac, V., Olive, J-A., Leleu, T., Rommevaux, C., Escartín, J., Jamieson, J., \& Petersen S. (2015). Thermo-chemical fluxes, reactions and mixing in hydrothermal 
1073

1074

1075

1076

1077

1078

1079

1080

1081

1082

1083

1084

1085

1086

1087

1088

1089

1090

1091

1092

1093

1094

1095

1096

1097

1098

1099

1100

1101

1102

plumes at oceanic core complexes (Mid-Atlantic Ridge, $13^{\circ} 30^{\prime} \mathrm{N}$ and $13^{\circ} 20^{\prime} \mathrm{N}$ ). Presented at AGU Meeting, San Francisco, USA, 14-18 Dec. 2015

Diamond, L.W., Tarantola, A., \& Stünitz, H. (2010). Modification of fluid inclusions in quartz by deviatoric stress II: experimentally induced changes in inclusion volume and composition. Contrib. Mineral. Petrol. 160, 845-864. https://doi.org/10.1007/s00410-010-0510-6

Dubessy, J., Poty, B., \& Ramboz, C. (1989). Advances in C-O-H-N-S fluid geochemistry based on micro-Raman spectrometric analysis of fluid inclusions. European Journal of Mineralogy, 1(4), 517-534. https://doi.org/10.1127/ejm/1/4/0517

Dunn, R.A., Arai, R., Eason, D.E., Canales, J.P., \& Sohn, R.A. (2017). Three-Dimensional Seismic Structure of the Mid-Atlantic Ridge: An Investigation of Tectonic, Magmatic, and Hydrothermal Processes in the Rainbow Area. Journal of Geophysical Research: Solid Earth, 122(12), 9580-9602. https://doi.org/10.1002/2017JB015051

Escartín, J., Mével, C., Petersen, S., Bonnemains, D., Cannat, M., Andreani, M., Augustin, N., Bezos, A., Chavagnac, V., Choi, Y., Godard, M., Haaga, K., Hamelin, C., Ildefonse, B., et al. (2017). Tectonic structure, evolution, and the nature of oceanic core complexes and their detachment fault zones $\left(13^{\circ} 20^{\prime} \mathrm{N}\right.$ and $13^{\circ} 30^{\prime} \mathrm{N}$, Mid Atlantic Ridge): Geochemistry, Geophysics, Geosystems, 18, (4), 1451-1482. https://doi.org/10.1002/2016GC006775

Escartín, J., Mével, C., MacLeod, C.J., \& McCaig, A.M. (2003). Constraints on deformation conditions and the origin of oceanic detachments: The Mid-Atlantic Ridge core complex at 1545’N. Geochemistry, Geophysics, Geosystems, 4(8), 1067. https://doi.org/10.1029/2001GC000278

Escartín, J., Smith, D.K., Cann, J., Schouten, H., Langmuir, C.H., \& Escrig, S. (2008). Central role of detachment faults in accretion of slow-spreading oceanic lithosphere. Nature, 455(7214), 790-794. https://doi.org/10.1038/nature07333

Fontaine, F.J., \& Wilcock, W.S.D. (2006). Dynamics and storage of brine in mid-ocean ridge hydrothermal systems. Journal of Geophysical Research, 111, B06102. https://doi.org/10.1029/2005JB003866

Fontaine, F.J., Wilcock, W.S.D., \& Butterfield, D.A. (2007). Physical controls on the salinity of mid-ocean ridge hydrothermal vent fluids. Earth and Planetary Science Letters, 257, 132145. https://doi:10.1016/j.eps1.2007.02.027 
1103

1104

1105

1106

1107

1108

1109

1110

1111

1112

1113

1114

1115

1116

1117

1118

1119

1120

1121

1122

1123

1124

1125

1126

1127

1128

1129

1130

1131

1132

1133

Fouquet, Y., Cambon, P., Etoubleau, J., Charlou, J.L., Ondréas, H., Barriga, F.J.A.S., Cherkashov, G., Semkova, T., Poroshina, I., Bohn, M., Donval, J.P., Henry, K., Murphy, P., \& Rouxel, O. (2010). Geodiversity of Hydrothermal Processes Along the Mid-Atlantic Ridge and Ultramafic-Hosted Mineralization: a New Type Of Oceanic Cu-Zn-Co-Au Volcanogenic Massive Sulfide Deposit, in Diversity Of Hydrothermal Systems On Slow Spreading Ocean Ridges, American Geophysical Union, p. 321-367

Foustoukos, D.I. \& Seyfried, W.E. (2005) Redox and pH constraints in the subseafloor root zone of the TAG hydrothermal system, $26^{\circ} \mathrm{N}$ Mid-Atlantic Ridge. Earth and Planetary Science Letters, 235, 497-510. https://doi.org/10.1016/j.eps1.2005.04.042

Frezzotti, M.L., Ferrando, S., Tecce, F., \& Castelli, D. (2012). Water content and nature of solutes in shallow-mantle fluids from fluid inclusions. Earth and Planetary Science Letters, 351352, 70-83. https://doi.org/10.1016/j.eps1.2012.07.023

Früh-Green, G.L., Kelley, D.S., Bernasconi, S.M., Karson, J.A., Ludwig, K.A., Butterfield, D.A., Boschi, C., \& Proskurowski, G. (2003) 30,000 Years of Hydrothermal Activity at the Lost City Vent Field. Science, 301, 495-498

Gillis, K., \& Thompson, G. (1993). Metabasalts from the Mid-Atlantic Ridge: new insights into hydrothermal systems in slow-spreading crust. Contrib. Mineral. Petrol., 113, 502-523

Godard, M., Lagabrielle, Y., Alard, O., \& Harvey, J. (2008). Geochemistry of the highly depleted peridotites drilled at ODP Sites 1272 and 1274 (Fifteen-Twenty Fracture Zone, Mid-Atlantic Ridge): Implications for mantle dynamics beneath a slow spreading ridge. Earth and Planetary Science Letters, 267(3-4), 410-425. https://doi.org/10.1016/j.epsl.2007.11.058

Hodgkinson, M.R.S., Webber, A.P., Roberts, S., Mills, R.A., Connelly, D.P., \& Murton, B.J. (2015). Talc-dominated seafloor deposits reveal a new class of hydrothermal system: Nature Communications, 6, 10150. https://doi.org/10.1038/ncomms10150

Holm, N.G., \& Charlou, J.L. (2001). Initial indications of abiotic formation of hydrocarbons in the Rainbow ultramafic hydrothermal system, Mid-Atlantic Ridge. Earth Planet. Sci. Lett., 191, 1-8.

Honnorez, J., Alt, J.C. \& Humphris, S.E. (1998). Vivesection and autopsy of active and fossil hydrothermal alteration of basalts beneath and whitin the TAG hydrothermal mound: Herzig, P.M., Humphris, S.E., Miller, D.J., and Zierenberg, R.A. (Eds.), Proceedings of the Ocean Drilling Program, Scientific Results, Vol. 158, p. 231-254 
1134 Humphris, S.E., \& Thompson, G. (1978). Hydrothermal alteration of oceanic basalts by seawater.

Geochim. Cosmochim. Acta 42, 107-125.

Humphris, S.E., Alt, J.C., Teagle, D.A.H., \& Honnorez, J.J. (1998). Geochemical changes during hydrothermal alteration of basement in the stockwork beneath the active TAG hydrothermal mound, in Proceedings of the Ocean Drilling Program, 158 Scientific Results, Ocean Drilling Program, p. 255-276.

Karson, J.A., Früh-Green, G.L., Kelley, D.S., Williams, E.A., Yoerger, D.R., \& Jakuba, M. (2006). Detachment shear zone of the Atlantis Massif core complex, Mid-Atlantic Ridge, $30^{\circ} \mathrm{N}$. Geochemistry, Geophysics, Geosystems, $\quad$ 7(6), Q06016. https://doi.org/10.1029/2005GC001109

Kelley, D.S., \& Delaney, J.R. (1987). Two-phase separation and fracturing in mid-ocean ridge gabbros at temperatures greater than $700{ }^{\circ}$ C. Earth. Planet. Sci. Lett., 83, 53-66

Kelley, D.S., Gillis, K.M., \& Thompson, G. (1993). Fluid evolution in submarine magmahydrothermal systems at the Mid-Atlantic Ridge. Journal of Geophysical Research, 98(B11), 19579-19596

Kelley, D.S., \& Robinson, P.T. (1990). Development of a brine-dominated hydrothermal system at temperatures of $400-500{ }^{\circ} \mathrm{C}$ in the upper level plutonic sequence, Troodos ophiolite, Cyprus. Geochim. Cosmochim. Acta, 54, 653-661

Kelley, D. S., Robinson P. T., \& Malpas, J. G. (1992). Processes of brine generation and circulation in the oceanic crust: Fluid inclusion evidence from the Troodos Ophiolite, Cyprus. J. Geophys. Res, 97, B6, 9307-9322.

Klein, F., Grozeva, N.G., \& Seewald, J.S. (2019). Abiotic methane synthesis and serpentinization in olivine-hosted fluid inclusions. Proceedings of the National Academy of Sciences, 116(36), 17666-17672. https://doi.org/10.1073/pnas.1907871116

Leisen, M., Boiron, M.C., Richard, A., \& Dubessy, J. (2012). Determination of Cl and Br concentrations in individual fluid inclusions by combining microthermometry and LAICPMS analysis: Implications for the origin of salinity in crustal fluids. Chemical Geology, 330-331, 197-206. https://doi.org/10.1016/j.chemgeo.2012.09.003

Locatelli, M., Verlaguet, A., Agard, P., Pettke, T., \& Federico, L. (2019). Fluid pulses during stepwise brecciation at intermediate subduction depths (Monviso eclogites, W. Alps): first 
internally then externally sourced, Geochemistry, Geophysics, Geosystems, 20(3). https://doi.org/10.1029/2019GC008549

1166

1167

1168

1169

1170

1171

1172

1173

1174

1175

1176

1177

1178

1179

1180

1181

1182

1183

1184

1185

1186

1187

1188

1189

1190

1191

1192

1193

Longerich, H. P., Jackson, S. E., \& Gunther, D. (1996). Laser ablation inductively coupled plasma mass spectrometric transient signal data acquisition and analyte concentration calculation. $J$. Anal. Atom. Spectrom. 11, 899-904

MacLeod, C.J., Escartín, J., Banerji, D., Banks, G.J., Gleeson, M., Irving, D.H.B., Lilly, R.M., McCaig, A., Niu, Y.-L., Allerton, S., \& Smith, D.K. (2002). Direct geological evidence for oceanic detachment fauling: The Mid-Atlantic Ridge, 1545’ N. Geology, 30(10), 279-282.

MacLeod, C.J., Searle, R.C., Casey, J.F., Mallows, C., Unsworth, M., Achenbach, K., \& Harris, M. (2009). Life cycle of oceanic core complexes. Earth and Planetary Science Letters, 287, 333-344

Mallows, C., \& Searle, R.C. (2012). A geophysical study of oceanic core complexes and surrounding terrain, Mid-Atlantic Ridge $13^{\circ} \mathrm{N}-14^{\circ} \mathrm{N}$. Geochemistry Geophysics Geosystems, 13(1), Q0AG08. https://doi.org/10.1029/2012GC004075

Martin, B., \& Fyfe, W. S. (1970). Some experimental and theoretical observations on the kinetics of hydration reactions with particular reference to serpentinization, Chem. Geol., 6, 185-202. https://doi.org/10.1016/0009- 2541(70)90018-5.

McCaig, A., Cliff, R.A., Escartin, J., Fallick, A.E., \& MacLeod, C.J. (2007). Oceanic deachment faults focus very large volumes of black smoker fluids. Geology, 35, 935-938. https://doi.org/10.1130/G23657A.1

McCaig, A.M., Delacour, A., Fallick, A.E., Castelain, T., \& Früh-Green, G.L. (2010). Detachment fault control on hydrothermal circulation systems: Interpreting the subsurface beneath the TAG hydrothermal field using the isotopic and geological evolution of oceanic core complexes in the Atlantic. Geophysical Monograph Series, 188, 207-239. https://doi.org/10.1029/2008GM000729

McCaig, A.M., \& Harris, M. (2012). Hydrothermal circulation and the dike-gabbro transition in the detachment mode of slow seafloor spreading. Geology, 40, 367-370

McCollom, T.M. \& Bach, W. (2009) Thermodynamic constraints on hydrogen generation during serpentinization of ultramafic rocks. Geochimica et Cosmochimica Acta, 73, 856-875. https://doi.org /10.1016/j.gca.2008.10.032 
1194

1195

1196

1197

1198

1199

1200

1201

1202

1203

1204

1205

1206

1207

1208

1209

1210

1211

1212

1213

1214

1215

1216

1217

1218

1219

1220

1221

1222

1223

McDermott, J.M., Seewald, J.S., German, C.R. \& Sylva, S.P. (2015) Pathways for abiotic organic synthesis at submarine hydrothermal fields. PNAS, 112(25), 7668-7672. https://doi.org /10.1073/pnas.1506295112

McDermott, J.M., Sylva, S.P., Ono, S., German, C.R. \& Seewald, J.S. (2018) Geochemistry of fluids from Earth's deepest ridge-crest hot-springs: Piccard hydrothermal field, Mid-Cayman Rise. Geochimica and Cosmochimica Acta, 228, 95-118. https://doi.org /10.1016/j.gca.2018.01.021

Monnin, C., Chavagnac, V., Boulart, C., Ménez, B., Gérard, M., Gérard, E., Quéméneur M., Erauso G., Postec A., Guentas-Dombrowski L., Payri C., \& Pelletier B. (2014). The low temperature hyperalkaline hydrothermal system of the Prony Bay (New Caledonia). Biogeosciences Discussion, 11, 5687-5706. https://doi:10.5194/bg-11-5687-2014

Mottl, M.J. (1983). Metabasalts, axial hot springs, and the structure of hydrothermal systems at mid- ocean ridges. Geol. Soc. Am. Bull. 94, 161-180

Olive, J.A., Parnell-Turner, R., Escartin, J., Smith, D.K., \& Petersen, S. (2019). Controls on the seafloor exposure of detachment fault surfaces. Earth and Planetary Science Letters, 506, 381-387. https://doi.org/10.1016/j.eps1.2018.11.001

Ondréas, H., Cannat, M., Fouquet, Y., \& Normand, A. (2012). Geological context and vents morphology of the ultramafic-hosted Ashadze hydrothermal areas (Mid-Atlantic Ridge $\left.13^{\circ} \mathrm{N}\right) . \quad$ Geochemistry Geophysics Geosystems, 13(1), Q0AG14. https://doi.org/10.1029/2012GC004433

Parnell-Turner, R., White, N., Henstock, T.J., Jones, S.M., Maclennan, J., \& Murton, B.J. (2017). Causes and Consequences of Diachronous V-Shaped Ridges in the North Atlantic Ocean. Journal of Geophysical Research: Solid Earth, 122(11), 8675-8708. https://doi.org/10.1002/2017JB014225

Parnell-Turner, R., Escartín, J., Olive, J.-A., Smith, D.K., \& Petersen, S. (2018). Genesis of corrugated fault surfaces by strain localization recorded at oceanic detachments. Earth and Planetary Science Letters, 498, 116-128. https://doi.org/10.1016/j.eps1.2018.06.034

Pasteris, J.D., Wopenka, B., \& Seitz, J.C. (1988). Practical aspects of quantitative laser Raman microprobe spectroscopy for the study of fluid inclusions. Geochimica et Cosmochimica Acta, 52, 979-988 
Paulick, H., Bach, W., Godard, M., de Hoog, J.C.M., Suhr, G., \& Harvey, J. (2006). Geochemistry of abyssal peridotites (Mid-Atlantic Ridge, $15^{\circ} 20^{\prime} \mathrm{N}$, ODP Leg 209): implications for fluidrock interaction in slow spreading environments. Chemical Geology, 234(3-4), 179-210

Pearce, N. J. G., Perkins, W. T., Westgate, J. A., Gorton, M. P., Jackson, S. E., Nael, C. R. \& Chenery, S. P. (1997). Compilation of new and published major trace element data for NIST 610 NIST SRM 612 glass reference materials. Geostand. Newslett. 21, 115-144.

Pertsev, A.N., Bortnikov, N.S., Vlasov, E.A., Beltenev, V.E., Dobretsova, I.G., \& Ageeva, O. A. (2012). Recent massive sulfide deposits of the Semenov ore district, Mid-Atlantic Ridge, $13^{\circ} 31^{\prime} \mathrm{N}$ : Associated rocks of the oceanic core complex and their hydrothermal alteration. Geology of Ore Deposits, 54(5), 334-346. https://doi.org/10.1134/S1075701512050030.

Petersen, S., Hertzig, M., \& Hannington, M.D. (1998). Fluid inclusion studies as a guide to the temperature regime within the TAG hydrothermal mound, $26^{\circ}$, Mid-Atlantic Ridge. In P.M. Hertzig, S.E. Humphris, D.J. Miller, R.A. Zierenberg (Eds.), Procedings of the Ocean Drilling Program, Scientific Results (vol. 158, pp. 163-178).

Petersen, S., Kuhn, K., Kuhn, T., Augustin, N., Hekinian, R., Franz, L., \& Borowski, C. (2009). The geological setting of the ultramafic-hosted Logatchev hydrothermal field $\left(14^{\circ} 45^{\prime} \mathrm{N}\right.$, Mid-Atlantic Ridge) and its influence on massive sulfide formation. Lithos, 112(1-2), 40-56. https://doi.org.10.1016/j.lithos.2009.02.008

Raimbourg, H., Thiéry, R., Vacelet, M., Ramboz, C., Cluzel, N., Le Trong, E., Yamaguchi, A., \& Kimura, G. (2014). A new method of reconstituting the P-T conditions of fluid circulation in an accretionary prism (Shimanto, Japan) from microthermometry of methane-bearing aqueous inclusions. Geochim. Cosmochim. Acta 125, 96-109. http://dx.doi.org/10.1016/j.gca.2013.09.025.

Roedder, E. (1984). Fluid Inclusions. Reviews in Mineralogy, Vol. 12, Mineralogical Society of America, $644 \mathrm{p}$.

Saccocia, P.J., \& Gillis, K.M. (1995). Hydrothermal upflow zones in the oceanic crust. Earth and Planetary Science Letters, 136, 1-16

Scheuermann, P.P., Tan, C. \& Seyfried,W.E. (2018) Quartz solubility in the two-phase region of the $\mathrm{NaCl}-\mathrm{H}_{2} \mathrm{O}$ system: an experimental study with application to the Piccard hydrothermal field, Mid-Cayman Rise. Geochemistry, Geophysics, Geosystems, 19, 3570-3582. https://doi.org/10.1029/2018GC007610. 
1255

1256

1257

1258

1259

1260

1261

1262

1263

1264

1265

1266

1267

1268

1269

1270

1271

1272

1273

1274

1275

1276

1277

1278

1279

1280

1281

1282

1283

1284

1285

Scheuermann, P.P., Xing, Y., Ding, K. \& Seyfried,W.E. (2020) Experimental measurement of $\mathrm{H}_{2}$ (aq) solubility in hydrothermal fluids: application to the Piccard hydrothermal field, MidCayman Rise. Geochemica and Cosmichimica Acta, (283), 22-39. https://doi.org/10.1016/j.gca.2020.05.020.

Schmidt, K., Garbe-Schönberg, D., Koschinsky, A., Strauss, H., Jost, C. L., Klevenz, V., \& Königer P. (2011). Fluid elemental and stable isotope composition of the Nibelungen hydrothermal field ( $8^{\circ} 18^{\prime} \mathrm{S}$, Mid-Atlantic Ridge): constraints on fluid-rock interaction in heterogeneous lithosphere. Chem. Geol., 280, 1-18.

Schroeder, T., \& John, B.E. (2004). Strain localization on an oceanic detachment fault system, Atlantis Massif, $30^{\circ} \mathrm{N}$, Mid-Atlantic Ridge. Geochemistry, Geophysics, Geosystems, 5(11), Q11007. https://doi.org/10.1029/2004GC00728.

Seyfried, W.E., Foustoukos, D.I. \& Fu, Q. (2007) Redox evolution and mass transfer during serpentinization: An experimental and theoretical study at 200 degrees C, 500 bar with implications for ultramafic-hosted hydrothermal systems at Mid-Ocean Ridges. Geochimica Et Cosmochimica Acta, 71, 3872-3886. https://doi.org/10.1016/j.gca.2007.05.015

Simão, N.M., Peirce, C., Funnell, M.J., Robinson, A.H., Searle, R.C., MacLeod, C.J., \& Reston, T.J. (2020). 3-D P-wave velocity structure of oceanic core complexes at $13^{\circ} \mathrm{N}$ on the MidAtlantic Ridge. Geophysical Journal International, 221(3), 1555-1579. https://doi.org/10.1093/gji/ggaa093

Simonov, V.A., Borovikov, A.A., Kotlyarov, A.V., Amplieva, E.E., \& Bortnikov, N.S. (2015). LAICP-MS evidence for high concentrations of metals in fluid from modern sea-floor hydrothermal systems: a case study of fluid inclusions in minerals from Semenov, Ashadze, and Logatchev sulfide edifices (Mid-Atlantic Ridge). Paper presented at the proceedings of the $13^{\text {th }}$ biennial SGA meeting, 24-27 August 2015, Nancy, France

Smith, D.K., Cann, J.R., \& Escartín, J. (2006). Widespread active detachment faulting and core complex formation near $13^{\circ} \mathrm{N}$ on the Mid-Atlantic Ridge. Nature, 442(7101), 440-443. https://doi.org/10.1038/nature04950

Smith, D.K., Escartin, J., Schouten, H., \& Cann, J.R. (2008). Fault rotation and core complex formation: Significant processes in seafloor formation at slow-spreading mid-ocean ridges (Mid-Atlantic Ridge, $13-15^{\circ}$ N). Geochemistry, Geophysics, Geosystems, 9(3), Q03003. https://doi.org/10.1029/2007GC001699 
Son, J., Pak, S.-J., Kim, J., Baker, E.T., You, O.-R., Son, S., \& Moon, J. (2014). Tectonic and magmatic control of hydrothermal activity along the slow-spreading Central Indian Ridge, $8^{\circ} \mathrm{S}-17^{\circ} \mathrm{S}$ Geochemistry, Geophysics, Geosystems, 15(5), 2011-2020. https://doi.org/10.1002/2013GC005206

Sourirajan, S. \& Kennedy, G.C. (1962). The system $\mathrm{H}_{2} \mathrm{O}-\mathrm{NaCl}$ at elevated temperatures and pressures, Am. J. Sci., 260, 115-141.

Spandler, C., Pettke, T., \& Rubatto, D. (2011). Internal and external fluid sources for eclogitefacies veins in the Monviso meta-ophiolite, Western Alps: Implications for fluid flow in subduction zones. Journal of Petrology, 52(6), 1207-1236. https://doi.org/10.1093/petrology/egr025

Steele-MacInnis, M., Bodnar, R.J., \& Naden, J. (2011). Numerical model to determine the composition of $\mathrm{H}_{2} \mathrm{O}-\mathrm{NaCl}-\mathrm{CaCl}_{2}$ fluid inclusions based on microthermometric and microanalytical data. Geochimica et Cosmochimica Acta, 75(1), 21-40. https://doi.org/10.1016/j.gca.2010.10.002

Tao, C., Seyfried, W.E., Lowell, R.P., Liu, Y., Liang, J., Guo, Z., Ding, K., Zhang, H., Liu, J., Qiu, L., Egorov, I., Liao, S., Zhao, M., Zhou, J., et al. (2020). Deep high-temperature hydrothermal circulation in a detachment faulting system on the ultra-slow spreading ridge. Nature Communications, 11(1), 1300. https://doi.org/10.1038/s41467-020-15062-w

Tarantola, A., Diamond, L.W., \& Stünitz, H. (2010). Modification of fluid inclusions in quartz by deviatoric stress. I: experimentally induced changes in inclusion shapes and microstructures. Contrib. Mineral. Petrol., 160, 825-843.

Tarantola, A., Diamond, L.W., Stünitz, H., Thust, A., \& Pec, M. (2010). Modification of fluid inclusions in quartz by deviatoric stress. III: influence of principal stresses on inclusion density and orientation. Contrib. Mineral. Petrol., 164, 537-550.

Tivey, M.K., Mills, R.A., \& Teagle, D.A.H. (1998). Temperature and salinity of fluid inclusions in anhydrite as indicators of seawater entrainment and heating in the TAG active mound. In: Herzig PM, Humphris SE, Miller DJ, Zierenberg RA (eds) Proceedings of the ocean drilling program, scientific results, vol 158. Ocean drilling program, College Station, 179-190

Touret, J.L.R. (2001). Fluids in metamorphic rocks. Lithos 55(1-4), 1-25. https://doi.org/10.1016/S0024-4937(00)00036-0 
Tucholke, B.E., Behn, M.D., Buck, W.R., \& Lin, J. (2008). Role of melt supply in oceanic detachment faulting and formation of megamullions. Geology, 36(6), 455-458. https://doi.org/10.1130/G24639A

Van den Kerkhof, A.M., \& Hein, U.F. (2001). Fluid inclusion petrography. Lithos, 55(1-4), 2747. https://doi.org/10.1016/S0024-4937(00)00037-2

Vanko, D.A. (1988). Temperature, pressure, and composition of hydrothermal fluids with their bearing on the magnitude of tectonic uplift at mid-ocean ridges, inferred from fluid inclusions in oceanic layer 3 rocks. J. Geophys. Res., 93, 4595-4611

Vanko, D. A., Wolfgang, B., Roberts, S., Yeats, C.J., \& Scott, S.D. (2004). Fluid inclusion evidence for subsurface phase separation and variable fluid mixing regimes beneath the deepsea PACMANUS hydrothermal field, Manus Basin back arc rift, Papua New Guinea. Journal of Geophysical Research, 109(B3), B03201. https://doi.org/10.1029/2003JB002579

Vidal, O., De Andrade, V., Lewin, E., Munoz, M., Parra, T., \& Pascarelli, S. (2006). P-Tdeformation-Fe3+/Fe2+ mapping at the thin section scale and comparison with XANES mapping: application to a garnet-bearing metapelite from the Sambagawa metamorphic belt (Japan). J. Metamorph. Geol., 24(7), 669-683

Vidal, O., \& Parra, T. (2000). Exhumation paths of high-pressure metapelites obtained from local equilibria for chlorite-phengite assemblages. Geol. J. 35(3-4), 139-161

Vidal, O., Parra, T., \& Trotet, F. (2001). A thermodynamic model for Fe-Mg aluminous chlorite using data from phase equilibrium experiments and natural pelitic assemblages in the 100$600{ }^{\circ} \mathrm{C}, 1-25 \mathrm{~kb}$ range. Am. J. Sci., 301(6), 557-592

Vidal, O., Parra, T., \& Vieillard, P. (2005). Thermodynamic properties of the Tschermak solid solution in Fe-chlorite: application to natural examples and possible role of oxidation. Am. Mineral., 90(2-3), 347-358

Vityk, M.O., \& Bodnar, R.J. (1995). Textural evolution of synthetic fluid inclusions in quartz during reequilibration, with applications to tectonic reconstruction. Contrib. Mineral. Petrol. $121,309-323$.

Walshe, J-L. (1986). A six-component chlorite solid solution model and the conditions of chlorite formation in hydrothermal and geothermal systems. Econ. Geol., 81, 681-703 
1345 Wetzel, L.R., \& Shock, E.L. (2000). Distinguishing ultramafic- from basalt-hosted submarine 1346 hydrothermal vent fluid compositions. Journal of Geophysical Research, 105(B4), 8319$1347 \quad 8340$

1348 Wilson, S.C., Murton, B.J., \& Taylor, R.N. (2013). Mantle composition controls the development 1349 of an Oceanic Core Complex. Geochemistry, Geophysics, Geosystems, 14, 1-18. 1350 https://doi.org/10.1002/ggge.20046.

1351 Zhang, Y.G., \& Frantz, J.D. (1987). Determination of the homogenization temperatures and 1352 densities of supercritical fluids in the system $\mathrm{NaCl}-\mathrm{KCl}-\mathrm{CaCl}_{2}-\mathrm{H}_{2} \mathrm{O}$ using synthetic fluid 1353 inclusions. Chemical Geology, 64, 335-350.

1354 


\section{Tables}

1356

1357 Table 1. Characteristics of the six fault rocks considered for this study. The outcrop numbers refer to Figure $1 \mathrm{~b}$ and to Bonnemains et 1358 al. (2017).

1359

\begin{tabular}{|c|c|c|c|c|c|c|c|c|c|c|c|c|}
\hline \multirow[b]{2}{*}{ Outcrop } & \multirow{2}{*}{$\begin{array}{l}\text { Sample \# } \\
\text { ODM_ROC_R } \\
\text { Referred to as }\end{array}$} & \multirow[b]{2}{*}{ IGSN } & \multirow[b]{2}{*}{ Latitude } & \multirow[b]{2}{*}{ Longitude } & \multirow[b]{2}{*}{$\begin{array}{l}\text { Depth } \\
\text { (m) }\end{array}$} & \multirow[b]{2}{*}{$\begin{array}{l}\text { Rock } \\
\text { type }\end{array}$} & \multirow[b]{2}{*}{ Texture } & \multirow[b]{2}{*}{ Mineralogical composition* } & \multirow[b]{2}{*}{ Quartz content } & \multicolumn{3}{|c|}{ Analyses } \\
\hline & & & & & & & & & & $\begin{array}{l}\text { Whole } \\
\text { rock }\end{array}$ & Chlorite & $\begin{array}{l}\text { Fluid } \\
\text { Inclusions }\end{array}$ \\
\hline 1 & $\begin{array}{l}\text { V547_115 } \\
\text { ODM115 }\end{array}$ & CNRS0000000115 & $13^{\circ} 18.96^{\prime} \mathrm{N}$ & $-44^{\circ} 53.43^{\prime} \mathrm{W}$ & 3159 & mafic & clast of breccia with vacuoles & Chl, Pl, Px, Pmp & absent & $\mathrm{x}$ & $\mathrm{x}$ & \\
\hline \multirow[t]{2}{*}{2} & $\begin{array}{l}\mathrm{V} 552 \_217 \\
\text { ODM217 }\end{array}$ & CNRS0000000221 & $13^{\circ} 19.22^{\prime} \mathrm{N}$ & $-44^{\circ} 53.31^{\prime} \mathrm{W}$ & 3113 & $\begin{array}{l}\text { mafic / } \\
\text { ultramaf } \\
\text { ic }\end{array}$ & $\begin{array}{l}\text { matrix-supported breccia with } \\
\text { a striated surface and } 4 \text { slip } \\
\text { zones }\end{array}$ & $\begin{array}{l}\text { clast: Tlc / Chl } \pm \text { Ttn } \\
\text { matrix: Tlc, Amp, Srp }\end{array}$ & absent & $\mathrm{x}$ & $\mathrm{x}$ & \\
\hline & $\begin{array}{l}\text { V552_218 } \\
\text { ODM218 }\end{array}$ & CNRS0000000222 & $13^{\circ} 19.22^{\prime} \mathrm{N}$ & $-44^{\circ} 53.28^{\prime} \mathrm{W}$ & 3133 & mafic & $\begin{array}{l}\text { matrix-supported breccia with } \\
\text { a striated surface and } 6 \text { slip } \\
\text { zones }\end{array}$ & $\begin{array}{l}\text { clast: } \mathrm{Chl} \pm \mathrm{Ttn} / \mathrm{Chl}+\mathrm{Qz} \\
\pm \text { Sulf }(\mathrm{Py}, \mathrm{Po}, \mathrm{Ccp}) \\
\text { matrix: } \mathrm{Qz}+\mathrm{Chl}+\operatorname{Sulf}(\mathrm{Py}, \\
\text { Po, Ccp) }\end{array}$ & high & $\mathrm{x}$ & $\mathrm{x}$ & $\mathrm{x}$ \\
\hline 3 & $\begin{array}{l}\text { V551_173 } \\
\text { ODM173 }\end{array}$ & CNRS0000000176 & $13^{\circ} 20.40^{\prime} \mathrm{N}$ & $-44^{\circ} 54.03^{\prime} \mathrm{W}$ & 3218 & $\begin{array}{l}\text { mafic / } \\
\text { ultramaf } \\
\text { ic }\end{array}$ & $\begin{array}{l}\text { matrix-supported breccia with } \\
\text { one side mostly matrix and the } \\
\text { other containing clasts }\end{array}$ & $\begin{array}{l}\text { clast: Tle, Amp / Chl } \pm \text { Ttn } \\
\text { matrix: Tlc, Chl } \pm \text { Qz } \pm \text { Sulf } \\
\text { (Py, Po) }\end{array}$ & $\begin{array}{l}\text { high on matrix- } \\
\text { supported side, mo- } \\
\text { derate on the other }\end{array}$ & $\mathrm{x}$ & $\mathrm{x}$ & $\mathrm{x}$ \\
\hline 4 & $\begin{array}{l}\text { V551_195 } \\
\text { ODM195 }\end{array}$ & CNRS0000000199 & $13^{\circ} 19.51^{\prime} \mathrm{N}$ & $-44^{\circ} 53.75^{\prime} \mathrm{W}$ & 2922 & mafic & clast-supported breccia & $\begin{array}{l}\text { clast: } \mathrm{Pl}+\mathrm{Amp}+\mathrm{Chl} \\
\text { matrix: fine-grained with sub- } \\
\text { mm clasts and rare Chl and } \\
\text { Qz grains }\end{array}$ & moderate & $\mathrm{x}$ & $\mathrm{x}$ & $\mathrm{x}$ \\
\hline 6 & $\begin{array}{l}\text { V550_155 } \\
\text { ODM155 }\end{array}$ & CNRS0000000157 & $13^{\circ} 19.40^{\prime} \mathrm{N}$ & $-44^{\circ} 54.04^{\prime} \mathrm{W}$ & 3104 & mafic & $\begin{array}{l}\text { matrix-supported breccia with } \\
\text { a striated surface and } 5 \text { slip } \\
\text { zones }\end{array}$ & $\begin{array}{l}\text { clast: } \mathrm{Chl} \pm \mathrm{Ttn} / \mathrm{Chl}+\mathrm{Qz} \pm \\
\text { Sulf }(\mathrm{Py}) \\
\text { matrix: } \mathrm{Qz}+\mathrm{Chl}+\mathrm{Sulf}(\mathrm{Py})\end{array}$ & high & $\mathrm{x}$ & $\mathrm{x}$ & $\mathrm{x}$ \\
\hline
\end{tabular}

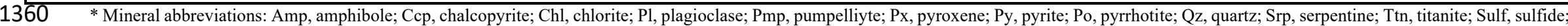

1361 Tlc, talc

1362

1363

1364

1365

1366

1367

1368

1369 
Table 2. Major and selected trace element whole-rock analyses of mafic and mixed mafic-ultramafic breccias from the detachment fault surface (see Table S1 for full analyses).

\begin{tabular}{|c|c|c|c|c|c|c|c|c|c|c|c|c|c|}
\hline \multicolumn{2}{|c|}{$\begin{array}{c}\text { Nature } \\
\text { Degree of silicification } \\
\text { Sample } \\
\end{array}$} & $\begin{array}{l}\text { Basaltic clast } \\
\text { Qz free } \\
\text { ODM115 } \\
\end{array}$ & $\begin{array}{c}\text { Mafic } \\
\text { Moderately Si } \\
\text { ODM195 } \\
\end{array}$ & $\begin{array}{c}\text { Mafic } \\
\text { Highly Si } \\
\text { ODM218a }\end{array}$ & $\begin{array}{c}\text { Mafic } \\
\text { Highly Si } \\
\text { ODM218b }\end{array}$ & $\begin{array}{c}\text { Mafic } \\
\text { Highly Si } \\
\text { ODM218 wr }\end{array}$ & $\begin{array}{c}\text { Mafic } \\
\text { Highly Si } \\
\text { ODM155 } \\
\end{array}$ & $\begin{array}{c}\text { Mixed } \\
\text { Qz free } \\
\text { ODM217a }\end{array}$ & $\begin{array}{c}\text { Mixed } \\
\text { Qz free } \\
\text { ODM217b }\end{array}$ & $\begin{array}{c}\text { Mixed } \\
\text { Qz free } \\
\text { ODM217 wr }\end{array}$ & $\begin{array}{c}\text { Mixed } \\
\text { Moderately Si } \\
\text { ODM173a } \\
\end{array}$ & $\begin{array}{c}\text { Mixed } \\
\text { Moderately Si } \\
\text { ODM173b } \\
\end{array}$ & $\begin{array}{c}\text { Mixed } \\
\text { Moderately Si } \\
\text { ODM173 wr }\end{array}$ \\
\hline $\mathrm{SiO}_{2}$ & wt.\% & 51.81 & 49.16 & 84.35 & 62.40 & 65.72 & 79.27 & 49.41 & 55.08 & 48.90 & 55.64 & 57.37 & 68.25 \\
\hline $\mathbf{A l}_{2} \mathbf{O}_{3}$ & wt. $\%$ & 13.76 & 13.05 & 2.69 & 4.12 & 3.78 & 2.43 & 5.46 & 2.26 & 5.25 & 9.05 & 1.50 & 5.18 \\
\hline $\mathrm{Fe}_{2} \mathrm{O}_{3}$ & wt. $\%$ & 8.16 & 10.76 & 6.30 & 19.97 & 17.09 & 9.47 & 11.25 & 8.07 & 12.50 & 13.79 & 10.04 & 11.07 \\
\hline MnO & wt. $\%$ & 0.16 & 0.22 & 0.06 & 0.08 & 0.08 & 0.06 & 0.33 & 0.39 & 0.45 & 0.11 & 0.07 & 0.07 \\
\hline MgO & wt. $\%$ & 6.08 & 11.88 & 2.43 & 4.33 & 4.08 & 2.10 & 22.70 & 22.93 & 21.30 & 11.24 & 20.49 & 8.18 \\
\hline $\mathrm{CaO}$ & wt. $\%$ & 11.27 & 4.57 & 0.28 & 0.48 & 0.30 & 0.28 & 4.32 & 6.72 & 5.33 & 0.24 & 0.09 & 0.17 \\
\hline $\mathrm{Na}_{2} \mathrm{O}$ & wt. $\%$ & 3.78 & 1.23 & $<$ D.L. & 0.11 & 0.07 & 0.05 & 0.22 & 0.20 & 0.24 & 0.29 & 0.28 & 0.17 \\
\hline $\mathrm{K}_{2} \mathrm{O}$ & wt. $\%$ & 0.09 & 0.04 & $<$ D.L. & $<$ D.L. & $<$ D.L. & 0.02 & 0.03 & 0.03 & 0.04 & 0.04 & 0.03 & 0.03 \\
\hline $\mathrm{TiO}_{2}$ & wt.\% & 1.37 & 0.65 & 0.17 & 0.27 & 0.26 & 0.15 & 0.42 & 0.12 & 0.40 & 0.49 & $<$ D.L. & 0.26 \\
\hline $\mathrm{P}_{2} \mathrm{O}_{5}$ & wt. $\%$ & 0.16 & $<$ D.L. & $<$ D.L. & $<$ D.L. & $<$ D.L. & $<$ D.L. & 0.06 & $<$ D.L. & 0.05 & 0.05 & $<$ D.L. & 0.04 \\
\hline PF & wt. $\%$ & 3.03 & 7.22 & 3.44 & 7.72 & 7.77 & 6.67 & 6.39 & 4.86 & 6.52 & 9.18 & 10.28 & 6.24 \\
\hline Total & wt.\% & 99.65 & 98.79 & 99.71 & 99.48 & 99.14 & 100.49 & 100.60 & 100.67 & 100.97 & 100.11 & 100.15 & 99.66 \\
\hline Mg \# & & 59.61 & 68.62 & 43.26 & 30.05 & 32.11 & 30.51 & 80.00 & 84.91 & 77.15 & 61.74 & 80.18 & 59.41 \\
\hline $\mathrm{FeO}$ & wt. $\%$ & 4.74 & 5.54 & 5.50 & 14.46 & 12.49 & 3.51 & 8.01 & 5.61 & 8.85 & 7.45 & 5.75 & 6.14 \\
\hline $\mathbf{S}$ & wt. $\%$ & 0.04 & 0.04 & 1.04 & 7.68 & 6.21 & 4.75 & 0.02 & 0.03 & 0.02 & 0.66 & 0.69 & 1.98 \\
\hline $\mathrm{Cr}$ & ppm & 308.50 & 349.30 & 293.70 & 590.40 & 525.60 & 303.30 & 1826.00 & 1895.00 & 2070.00 & 934.30 & 3319.00 & 1214.00 \\
\hline $\mathrm{Cu}$ & $\mathrm{ppm}$ & 66.84 & 11.68 & 87.36 & 564.10 & 697.30 & 19.05 & 874.20 & 450.80 & 1540.00 & 504.20 & 1609.00 & 605.20 \\
\hline $\mathbf{N i}$ & $\mathrm{ppm}$ & 112.80 & 126.40 & 140.40 & 492.70 & 385.90 & 190.70 & 1080.00 & 1180.00 & 1064.00 & 429.50 & 1609.00 & 710.70 \\
\hline Zn & ppm & 60.02 & 105.60 & 45.73 & 56.51 & 64.18 & 33.78 & 139.50 & 115.00 & 161.80 & 237.90 & 2947.00 & 379.70 \\
\hline
\end{tabular}

Table 3. Microthermometric measurements in fluid inclusions and Raman spectroscopy results.

\begin{tabular}{|c|c|c|c|c|c|c|c|c|c|}
\hline \multirow[t]{2}{*}{ Sample } & \multirow{2}{*}{$\begin{array}{l}\text { Quartz } \\
\text { location }\end{array}$} & \multirow[t]{2}{*}{$\mathrm{Nb}$} & \multicolumn{3}{|c|}{$\operatorname{Th}\left({ }^{\circ} \mathrm{C}\right)$} & \multicolumn{3}{|c|}{ Salinity (wt. $\% \mathrm{NaCl}$ eq.) } & \multirow[t]{2}{*}{ Gases other than $\mathrm{H}_{2} \mathrm{O}$ in fluid inclusions, analyzed by Raman spectroscopy } \\
\hline & & & Range & Average & SD & Range & Average & SD & \\
\hline ODM195 & Matrix & 19 & $149-218$ & 182 & 16 & $4.3-5.9$ & 5.2 & 0.5 & $12 \mathrm{FI}$ studied - no gas detected \\
\hline \multirow[t]{3}{*}{ ODM155 } & All & 24 & $183-322$ & 263 & 25 & $3.5-5.9$ & 4.8 & 0.3 & \\
\hline & - Matrix & 14 & $197-286$ & 258 & 24 & $4.3-5.9$ & 4.9 & 0.4 & $17 \mathrm{FI}$ studied -2 with $\mathrm{CO}_{2}$ only \\
\hline & - Clasts & 10 & $183-322$ & 271 & 23 & $3.5-5.3$ & 4.7 & 0.3 & \\
\hline \multirow[t]{3}{*}{ ODM218b } & All & 30 & $260-336$ & 318 & 9 & $4.8-10.2$ & 7.6 & 0.9 & \\
\hline & - Matrix & 6 & $260-329$ & 305 & 25 & $6.2-6.9$ & 6.4 & 0.3 & $28 \mathrm{FI}$ studied -7 with $\mathrm{H}_{2}$ only. 6 with $\mathrm{H}_{2}+\mathrm{CO}_{2} .2$ with $\mathrm{H}_{2}+\mathrm{CH}_{4}$ \\
\hline & - Clasts & 24 & $310-336$ & 321 & 5 & $4.8-10.2$ & 7.9 & 0.8 & \\
\hline ODM218c & Matrix & 36 & $258-348$ & 317 & 12 & 2.4-6.2 & 4.3 & 0.8 & $21 \mathrm{FI}$ studied - 11 with $\mathrm{H}_{2}$ only. 1 with $\mathrm{H}_{2}+\mathrm{CO}_{2} .3$ with $\mathrm{H}_{2}+\mathrm{CH}_{4} .2$ with $\mathrm{H}_{2}+\mathrm{CO}_{2}+\mathrm{CH}_{4} .4$ with $\mathrm{H}_{2}+\mathrm{CO}_{2}+\mathrm{CH}_{4}+\mathrm{H}_{2} \mathrm{~S}$ \\
\hline ODM173 & Matrix & 10 & $153-177$ & 176 & 13 & 3.9-6.4 & 4.6 & 0.8 & 6 FI studied - no gas detected \\
\hline
\end{tabular}

Nb: number of fluid inclusions; SD: standard deviation 

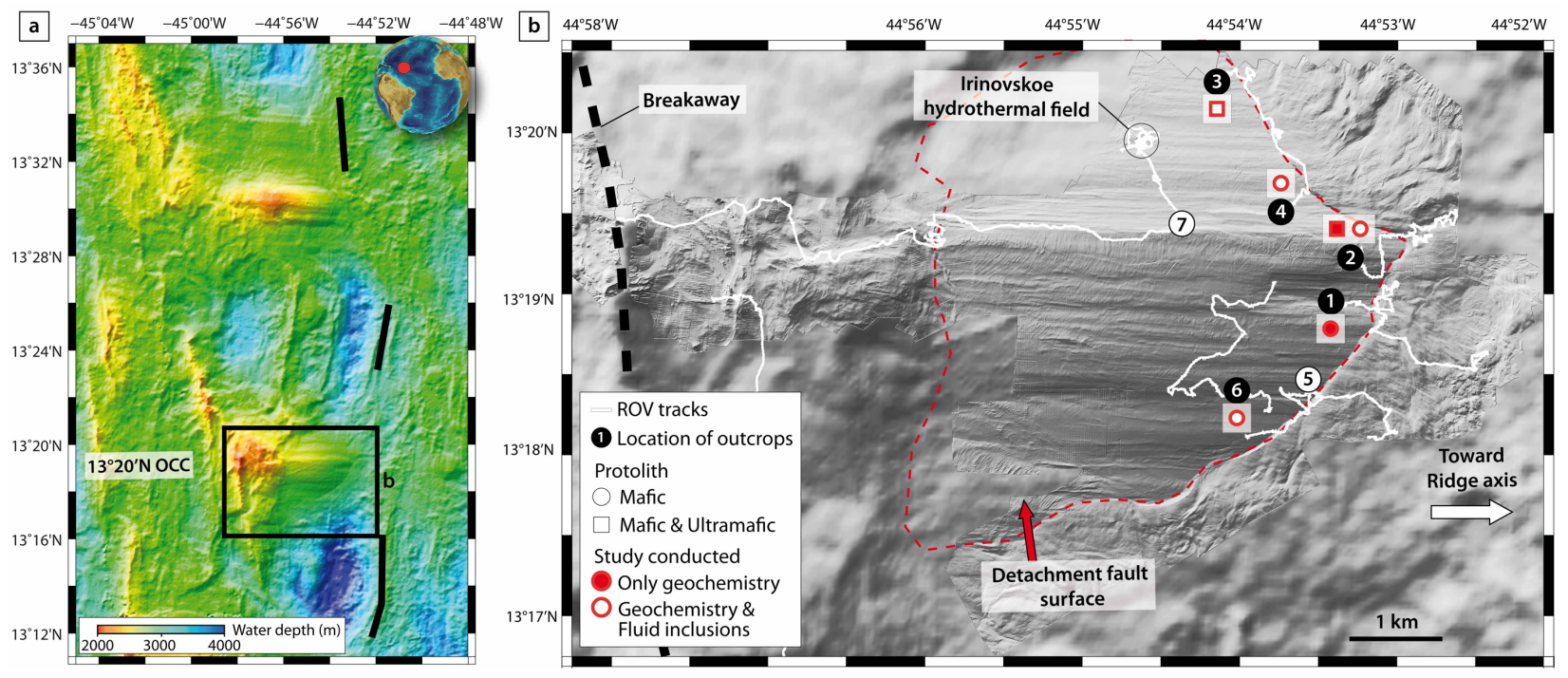

1383 Figure 1: (a) Multibeam bathymetry data of the $13^{\circ} 20^{\prime} \mathrm{N}$ detachment region, showing the core 1384 complex (black box) and the ridge axis (thick black lines). (b) Shaded relief microbathymetry 1385 acquired with the AUV Abyss (GEOMAR), collected during the ODEMAR cruise 1386 (https://doi.org/10.17600/13030070) over the $13^{\circ} 20^{\prime} \mathrm{N}$ OCC, complemented with shipboard 1387 bathymetry. White lines are tracks of ten ROV dives. Fault surface outcrops identified and sampled 1388 with the ROV are shown by a circle (see Bonnemains et al., 2017). Samples used for this study 1389 come from five of them (black numbered circles and associated red symbols, see Table 1 for 1390 details). 

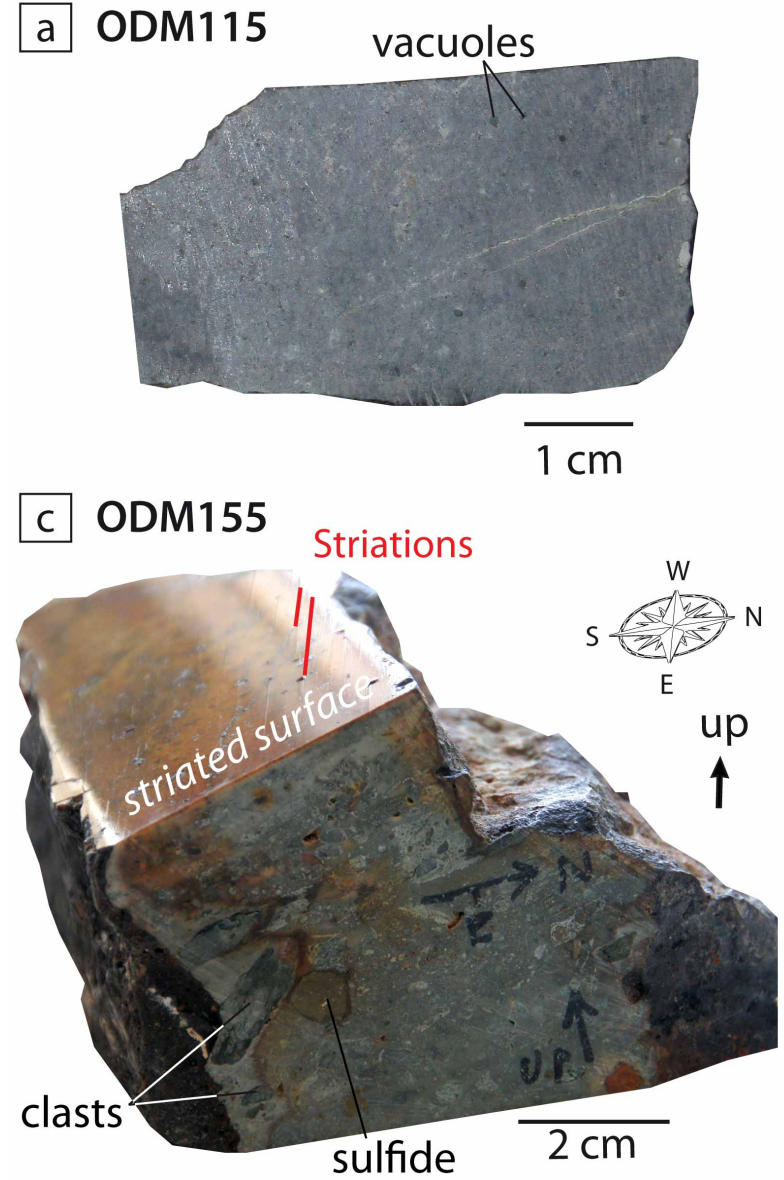

e ODM217

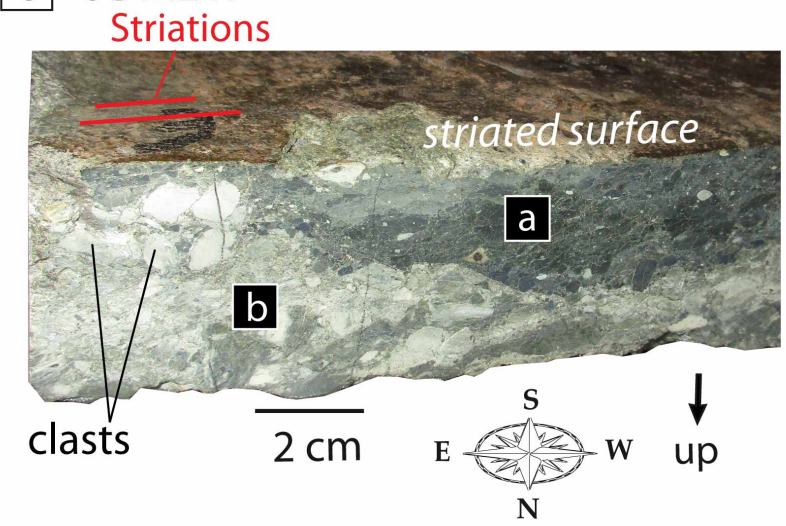

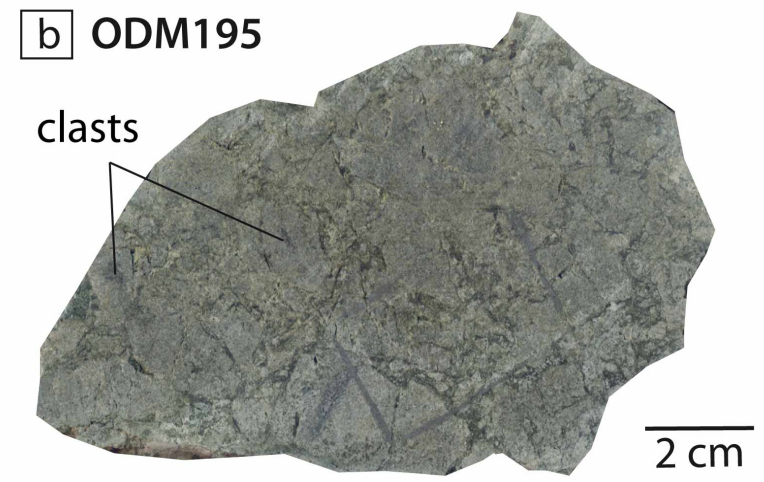
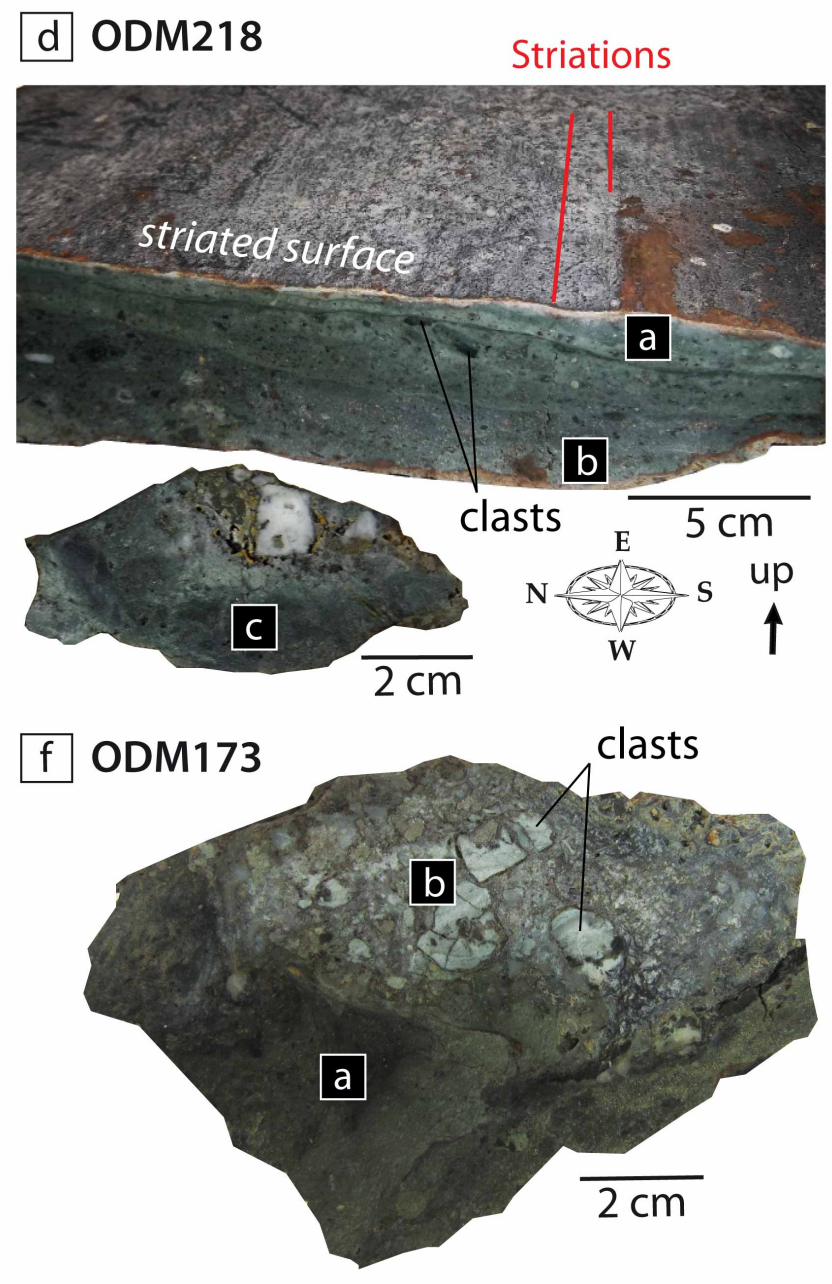

Figure 2: Macro-photographs of the studied fault rocks. (a) Clast of metabasalt with no quartz 1394 ODM115. (b) Moderately silicified mafic breccia ODM195. (c) Highly silicified mafic breccia ODM155. (d) Highly silicified mafic breccia ODM218 that is distinguished in two parts 1396 (subsamples a and b) at different distance from the striated surface (or slip plane) and a fragment 1397 dislodged from the lower part of sample (subsample ODM218c). (e) Unsilicified mafic-ultramafic 1398 breccia ODM217. We identify two parts based on the difference in color and mineralogical 
1399 composition between these slip layers. (f) Silicified mafic-ultramafic breccia ODM173 with 1400 ODM173a richer in quartz than ODM173b. All samples were recovered in situ at the detachment 1401 fault zone. 

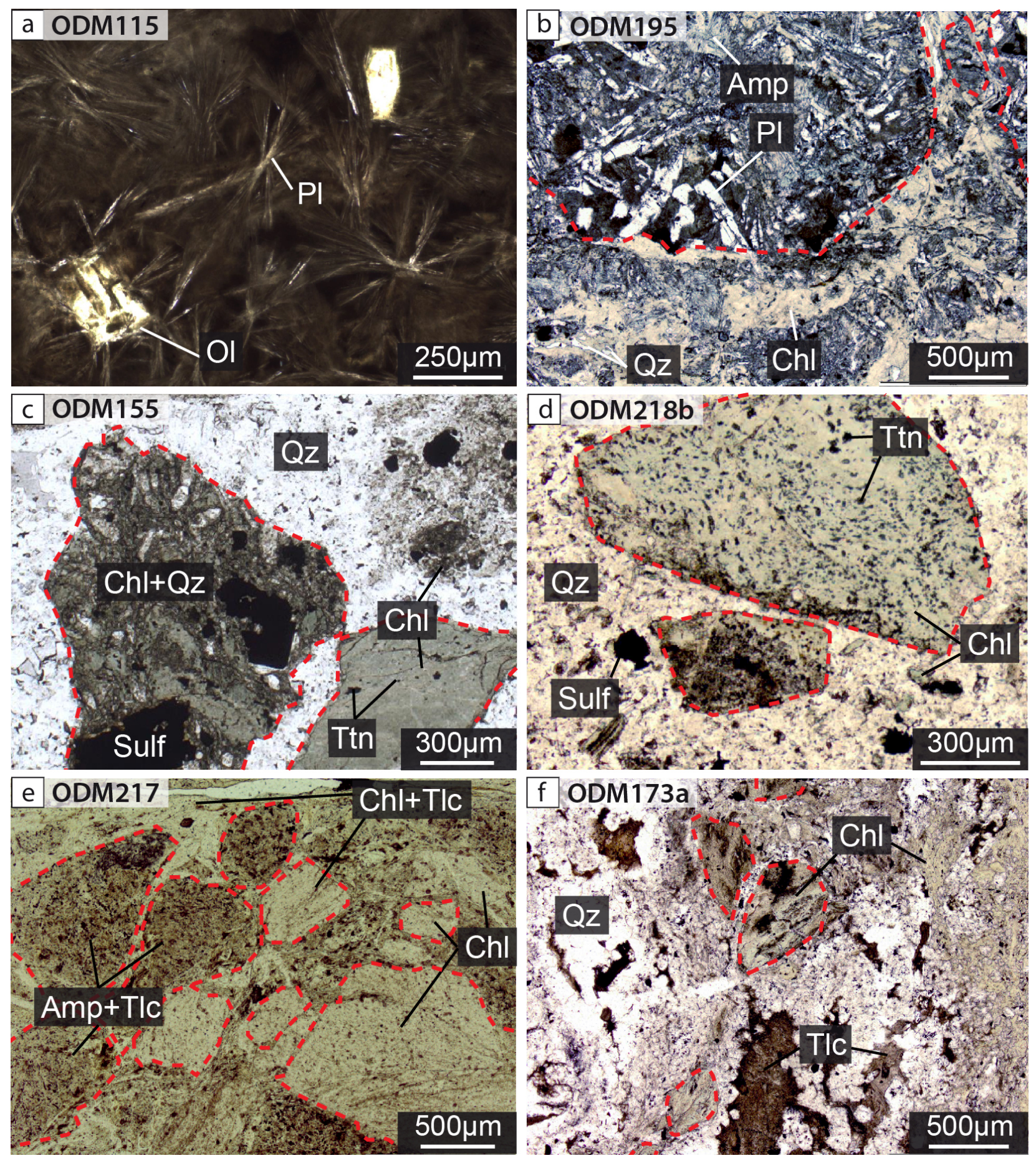

Figure 3: Microphotographs of studied samples in plane polarized light. (a) Unsilicified mafic

1405 clast showing basaltic texture with radiating plagioclase $(\mathrm{Pl})$ laths and dendritic olivine $(\mathrm{Ol})$

1406 crystals. (b) Moderately silicified mafic breccia contains clasts displaying a doleritic texture, made 1407 of amphibole (Amp) + plagioclase \pm chlorite (Chl), surrounded by a matrix consisting of crushed 1408 clasts mixed with chlorite and quartz (Qz). (c, d) Highly silicified mafic breccias containing clasts 
1409 of chlorite \pm titanite (Ttn) and chlorite \pm quartz \pm sulfide (Sulf), in a matrix mainly composed of

1410 quartz and minor chlorite and sulfide. In one of the clasts (c), the doleritic texture is still visible.

1411 (e) Unsilicified and (f) silicified mafic-ultramafic breccias containing both mafic (made of chlorite $1412 \pm$ titanite) and ultramafic (made of talc, Tlc, and amphibole) clasts embedded in a matrix composed 1413 of chlorite and talc, in addition to quartz for sample (f). (e) corresponds to zone a in Figure $2 \mathrm{f}$. 1414 Clasts are delimited by red dotted lines.

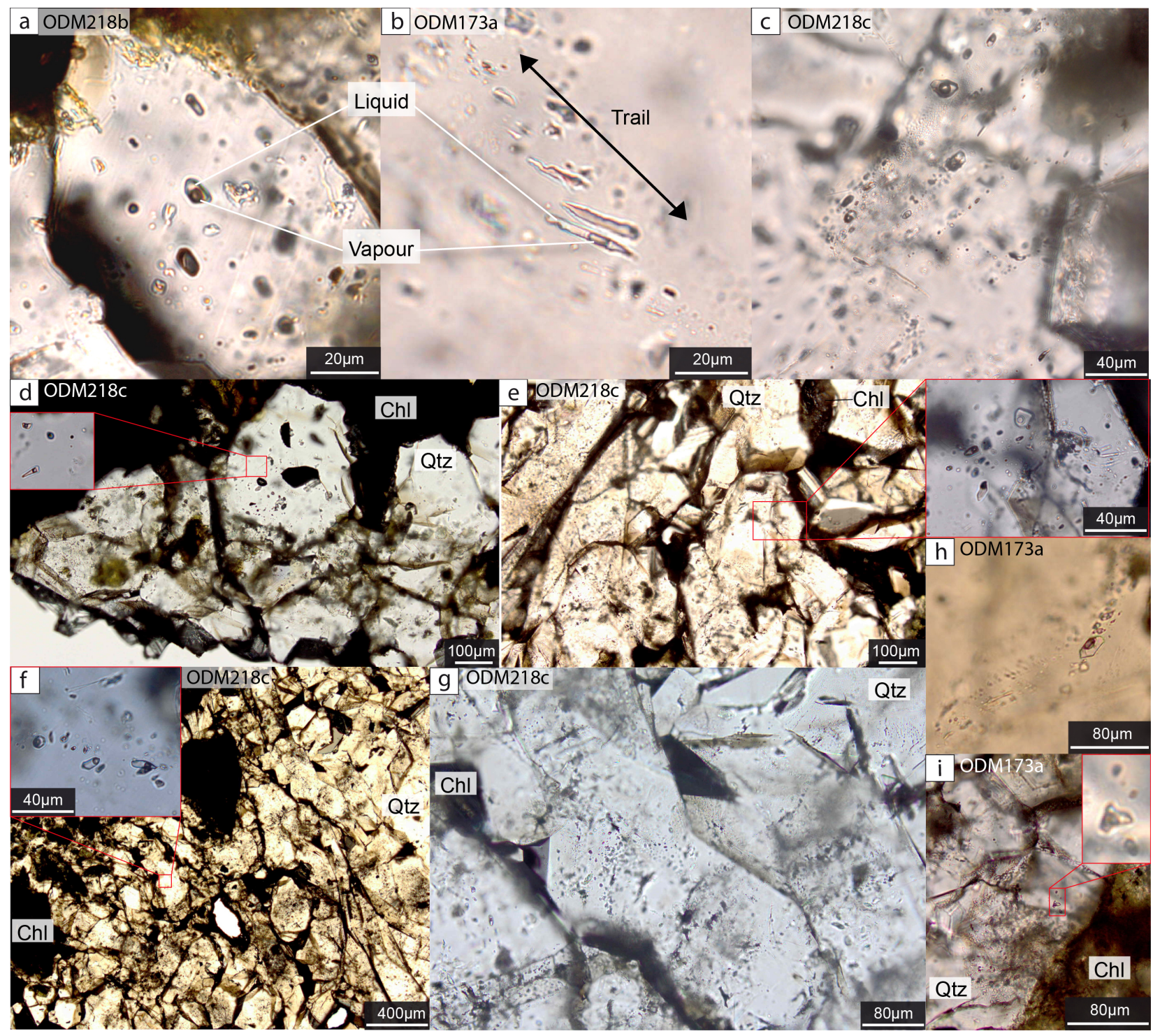

Figure 4: Microphotographs of representative two-phase (liquid and vapor) fluid inclusions in quartz grains. Clustered fluid inclusions with similar vapor/liquid ratios are considered as primary 1419 (a, d; e; i); fluid inclusions organized in trails are considered as secondary inclusions (b, c, f, g, h). 
1420 Note that most trails are intragrain trails, restricted to one quartz grain, while only few trails 1421 crosscut several quartz grain boundaries (g). Qtz: quartz; Chl: chlorite.
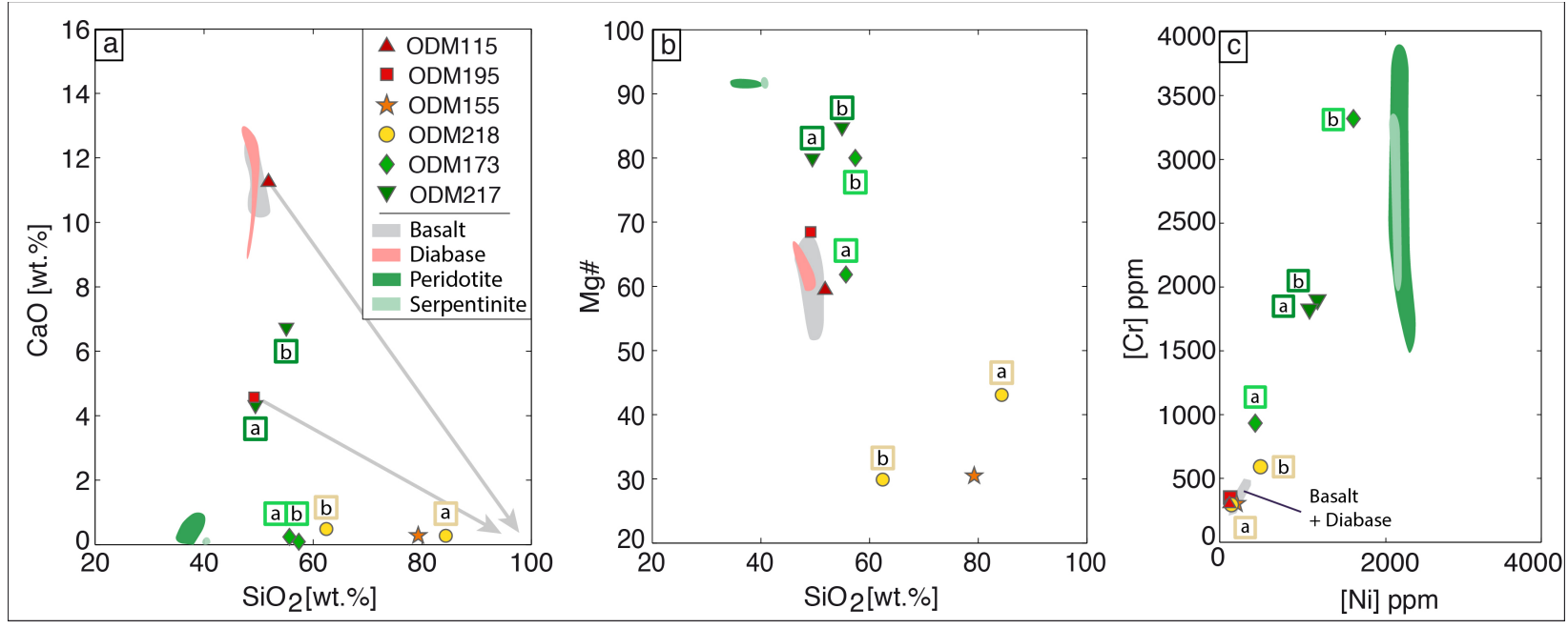

1426 Figure 5: Bulk rock geochemistry. $\mathrm{SiO}_{2}$ versus (a) $\mathrm{CaO}$ and (b) $\mathrm{Mg \#}(=\mathrm{Mg} /(\mathrm{Mg}+\mathrm{Fe}) * 100)$;

1427 brecciated rocks show a relative decrease in both $\mathrm{CaO}$ and $\mathrm{Mg \#}$ with increasing degree of 1428 silicification; mixed mafic-ultramafic breccias (green symbols) tend to be higher in magnesium at 1429 a given silica content; grey arrows: trend of passive depletion of $\mathrm{CaO}$ in breccias due to silica 1430 addition; Mg\# will not be affected by silica addition. (c) Cr vs Ni; mixed breccias tend to be 1431 enriched in nickel and chromium compared with purely mafic breccias. Data for basalts and 1432 diabases from the $13^{\circ} 20^{\prime} \mathrm{N}$ OCC (Wilson et al., 2013) and for peridotites from the $15^{\circ} 20^{\prime} \mathrm{N}$ Fracture 1433 Zone (Godard et al., 2008; Paulick et al., 2006) are shown for comparison. Data are available in 1434 Table 2. 

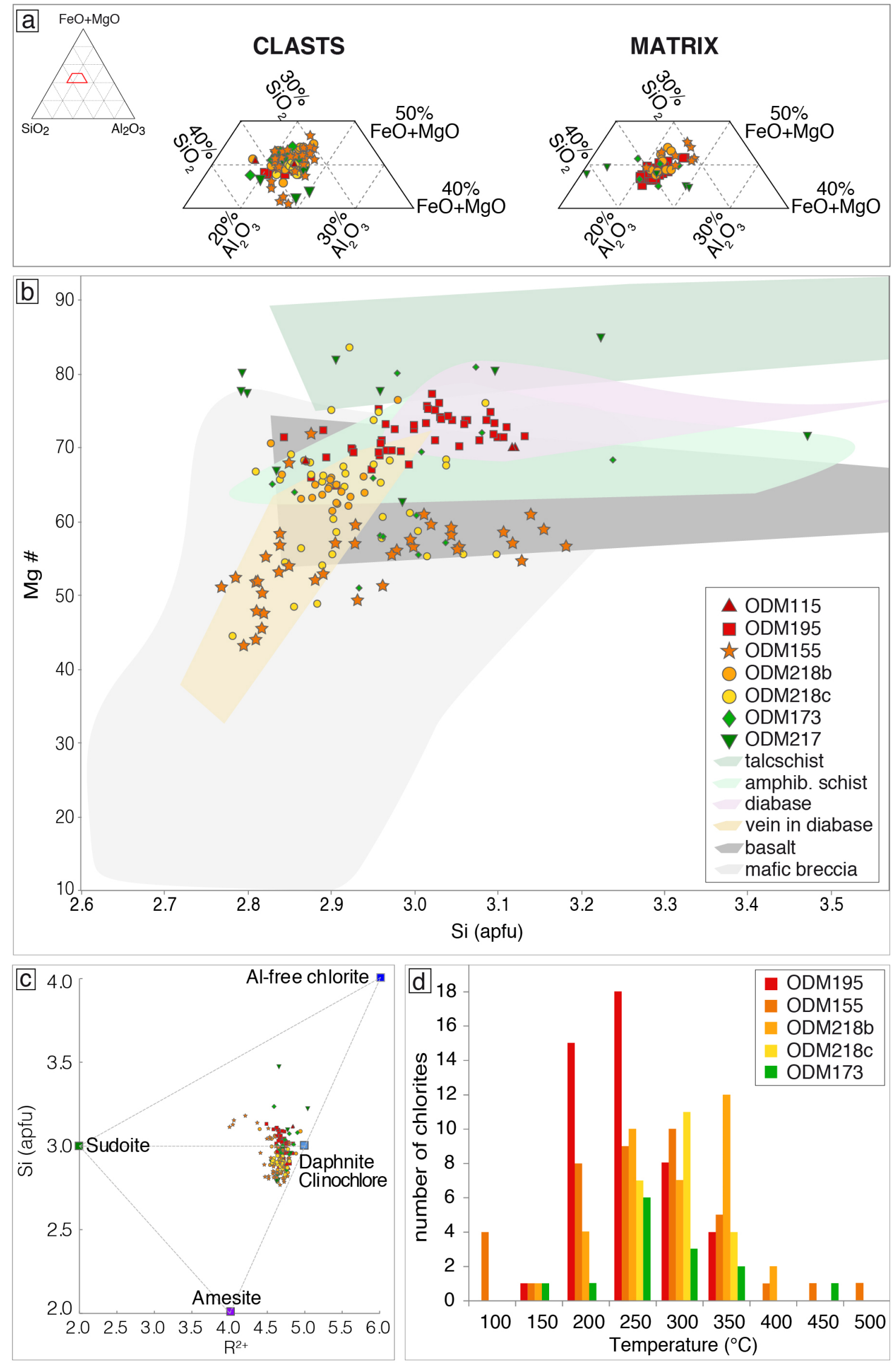
1436 Figure 6: Chlorite composition in clasts and matrices (a) in a $\mathrm{FeO}+\mathrm{MgO}, \mathrm{Al}_{2} \mathrm{O}_{3}, \mathrm{SiO}_{2}$ ternary

1437 diagram; (b) Mg\# versus Si (atoms per formula unit); chlorite compositions are compared to

1438 other oceanic chlorites from ultramafic rocks (talcschists from $15^{\circ} 45^{\prime} \mathrm{N}$ : Escartín et al., 2003, and

1439 south of Atlantis Massif: Boschi et al., 2006); mixed mafic-ultramafic amphibolite schists

1440 (Escartín et al., 2003); mafic rocks (diabases: Escartín et al., 2003; basalts from MAR: Humphris

1441 \& Thompson, 1978, and from MARK: Gillis and Thompson, 1993); altered mafic rocks

1442 (silicified breccias from MARK: Delaney et al., 1987; Saccocia and Gillis, 1995; chlorite-quartz

1443 vein in diabase, Atlantis Massif: Castelain et al., 2014); (c) Si versus $\mathrm{R}^{2+}$ diagram with chlorite

1444 endmembers; (d) Histogram of chlorite crystallization temperatures estimated using the semi-

1445 empirical geothermometer of Bourdelle et al. (2013). Chlorite analyses and calculated

1446 temperatures are available in Tables S2 and S4.

1447
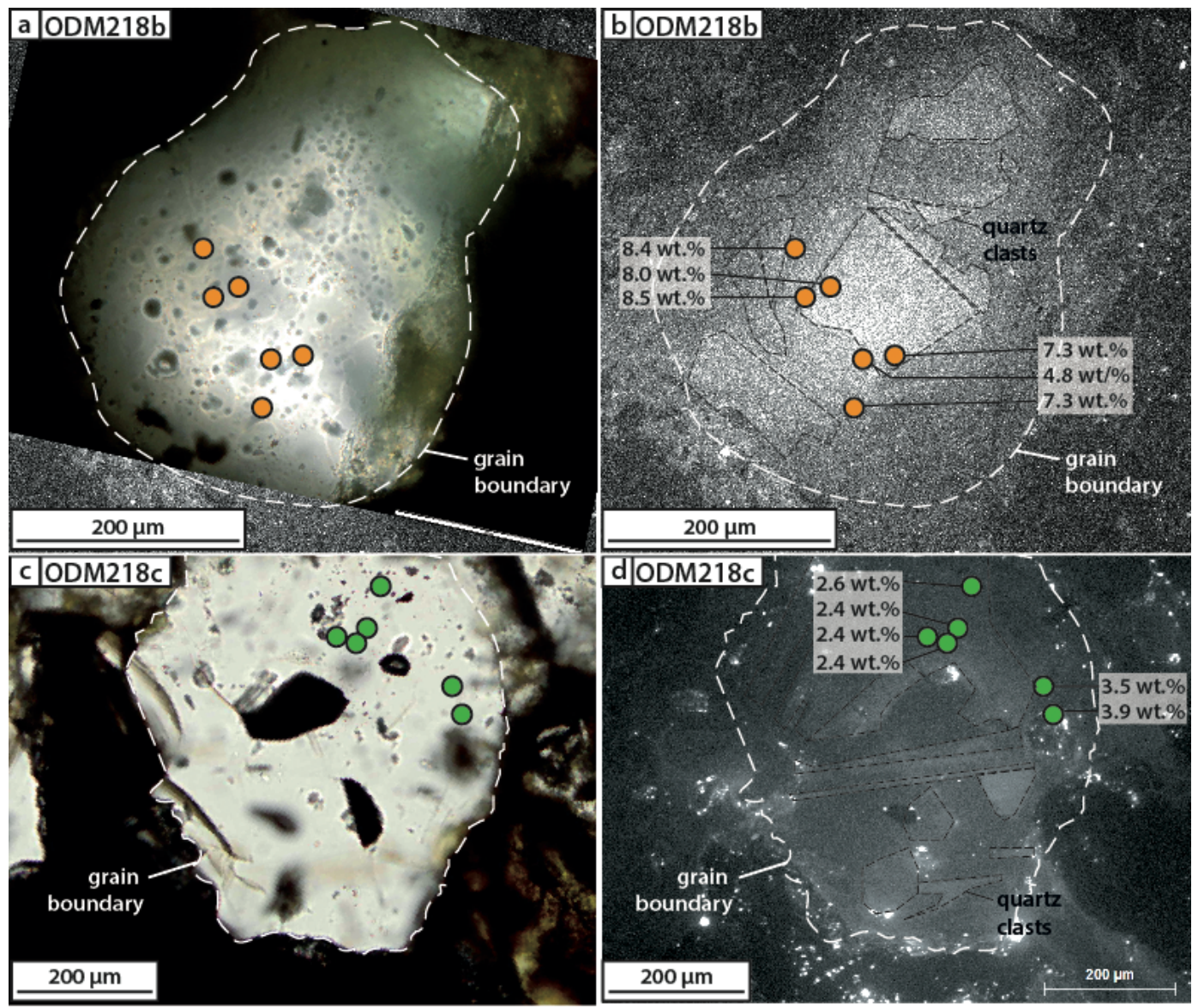

1449 Figure 7: Distribution of measured fluid inclusions in quartz grains from ODM218b (a and b, 1450 orange dots) and ODM218c (c and d, green dots). Microphotographs under parallel nicols showing 
1451 individual quartz crystals in ODM218b (a) and in ODM218c (c). SEM-cathodoluminescence image 1452 of the same quartz grains in ODM218b (b) and in ODM218c (d); grain boundary shown by the 1453 white dashed line; luminescence variations illustrate that quartz grains are composed of multiple 1454 former quartz angular clasts (black dotted lines) around which quartz recrystallized in successive 1455 generations. Quartz crystallization was obviously syntectonic, with successive steps of quartz 1456 growth-hydrofracturing-overgrowth. The large salinity (indicated in wt.\% $\mathrm{NaCl}$ equivalent) 1457 variation for fluid inclusions at the quartz grain scale suggests that fluids with different salinities 1458 were circulating (and thus trapped) during the successive episodes of quartz growth. Note that the 1459 position of fluid inclusions was projected on the grain surface, while inclusions are in fact 1460 distributed at various depths in the quartz grain.

1461

1462

1463

1464

1465

1466

1467

1468

1469

1470

1471
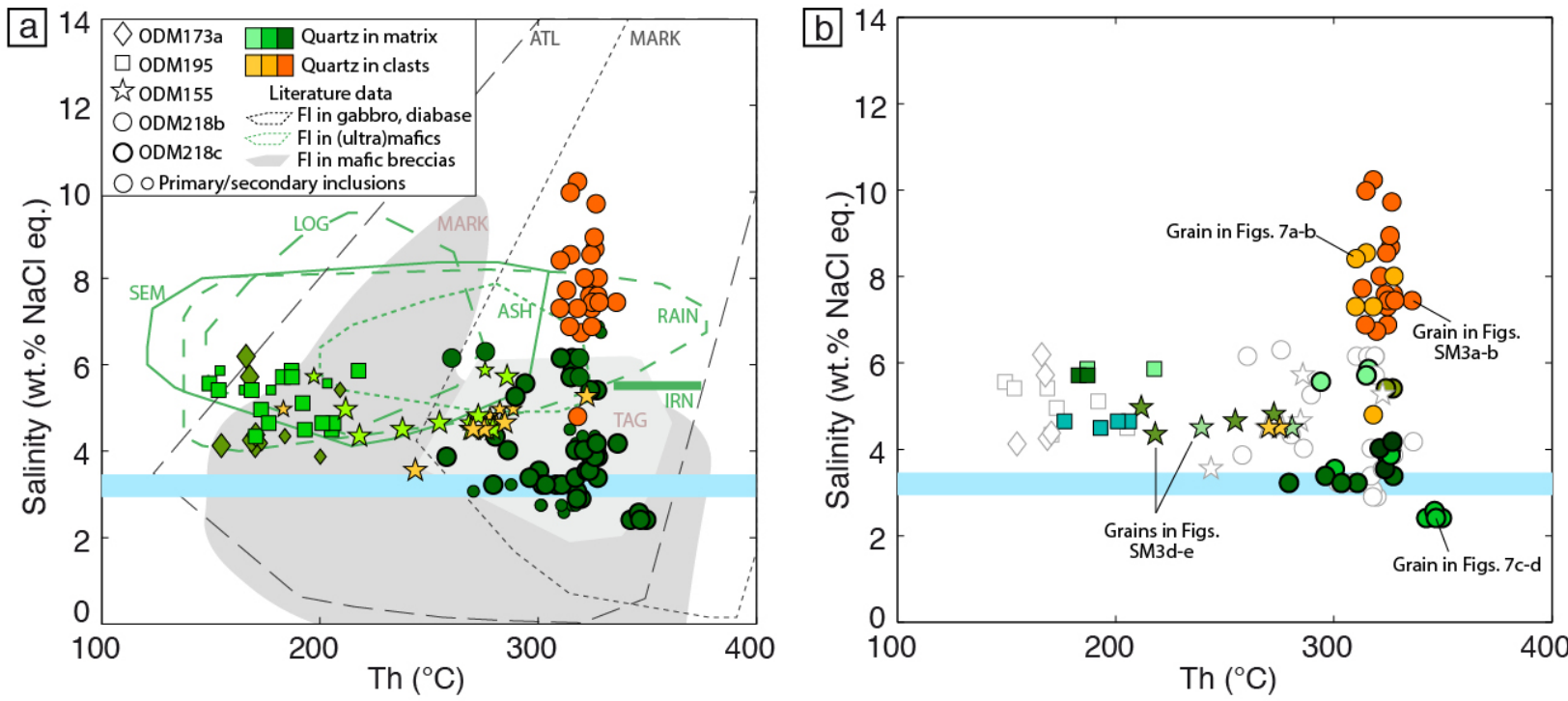

Figure 8: Homogenization temperatures (Th) against salinity for (a) all primary and secondary fluid inclusions; data are compared to Th and salinity ranges measured in fluid inclusions from oceanic gabbros (MARK: Kelley and Delaney, 1987), diabases (Atlantis Massif: Castelain et al., 2014), mafic silicified breccias from MARK (Delaney et al., 1987; Saccocia and Gillis, 1995) and TAG (Petersen et al., 1998), detachment plane (ultra)mafic rocks hosting hydrothermal vents (Rainbow, Logatchev, Ashadze, Semenov, Irinovskoe; Bortnikov et al., 2011, 2014, 2015; Simonov et al., 2015); (b) Heterogeneity of inclusion Th and salinity at the sample scale for the primary inclusions only, for clarity issues, using a similar color and symbol for inclusions in each grain. Seawater salinity is indicated with a blue line. 


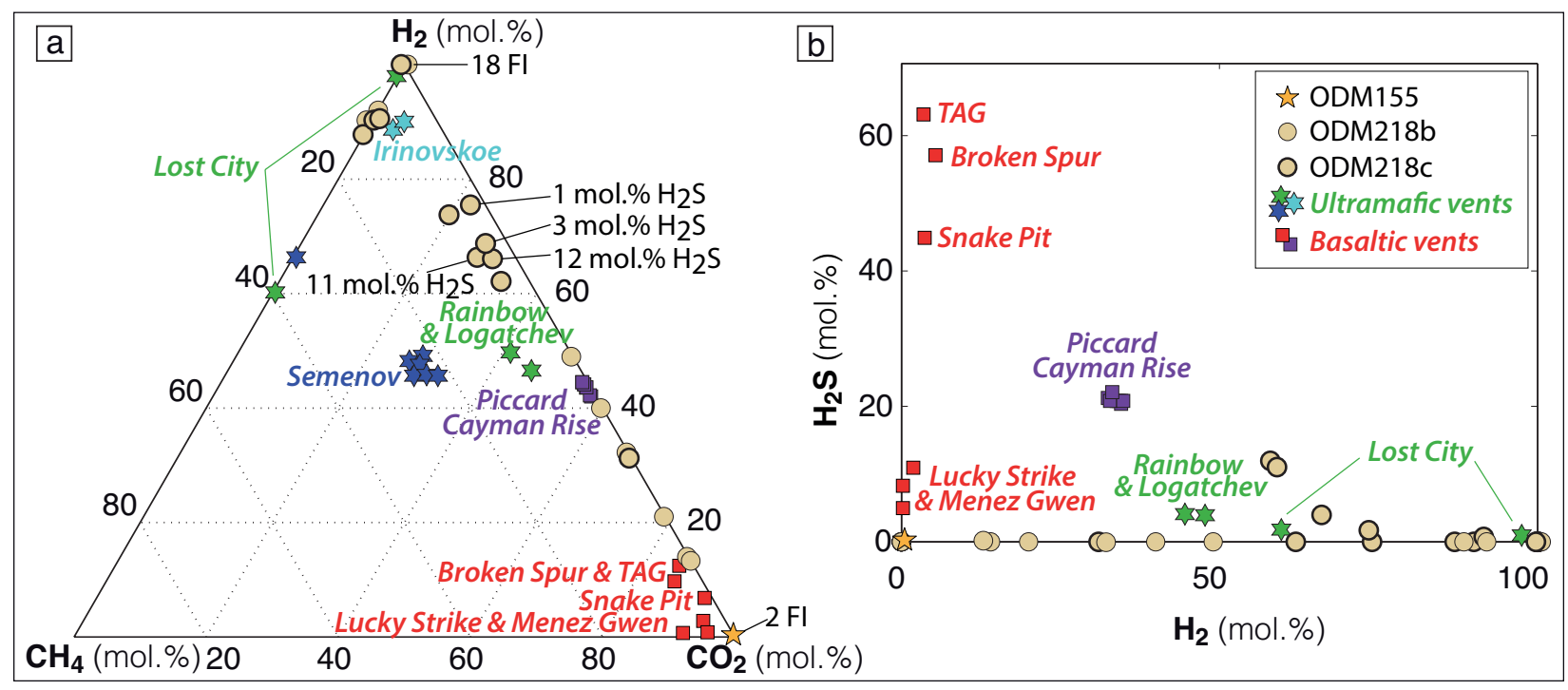

1473 Figure 9: Molar proportion of gases (other than $\mathrm{H}_{2} \mathrm{O}$ ) analyzed by Raman spectroscopy in the 1474 vapor phase of two-phase fluid inclusions for the two highly silicified mafic breccias ODM155 and 1475 ODM218. All fluid inclusions are dominantly aqueous, and $\mathrm{H}_{2} \mathrm{O}$ vapor is the dominant gas phase.

1476 (a) Relative molar proportions of $\mathrm{CH}_{4}, \mathrm{CO}_{2}$ and $\mathrm{H}_{2}$ in the gas phase. Gases other than $\mathrm{H}_{2} \mathrm{O}$ were 1477 analyzed in only 2 inclusions (over 17 analyzed) for ODM155 (and contain only $\mathrm{CO}_{2}$ other than $1478 \mathrm{H}_{2} \mathrm{O}$ vapor), in 15 inclusions over 28 analyzed for ODM218b, and in the 21 fluid inclusions 1479 analyzed in ODM218c. 7 and 11 fluid inclusions contain only $\mathrm{H}_{2}$ (other than $\mathrm{H}_{2} \mathrm{O}$ vapor) in 1480 ODM218b and ODM218c, respectively. (b) $\mathrm{H}_{2}$ versus $\mathrm{H}_{2} \mathrm{~S}$ content in fluid inclusions (expressed 1481 as a mol.\% of $\mathrm{CH}_{4}-\mathrm{CO}_{2}-\mathrm{H}_{2}-\mathrm{H}_{2} \mathrm{~S}$ in the vapor phase). Fluid inclusion gas compositions are 1482 compared to data from basaltic- (Menez Gwen, Broken Spur, TAG, Snake Pit, Lucky Strike) and 1483 ultramafic- (Rainbow, Logatchev, Lost City) derived hydrothermal vents (Fouquet et al., 2010). 1484 Data from Semenov and Irinovskoe ultramafic-derived vents (Destrigneville et al., 2015) and from 1485 Piccard mafic-derived vents on Cayman Rise (McDermott et al., 2018) are also plotted for 1486 comparison. 


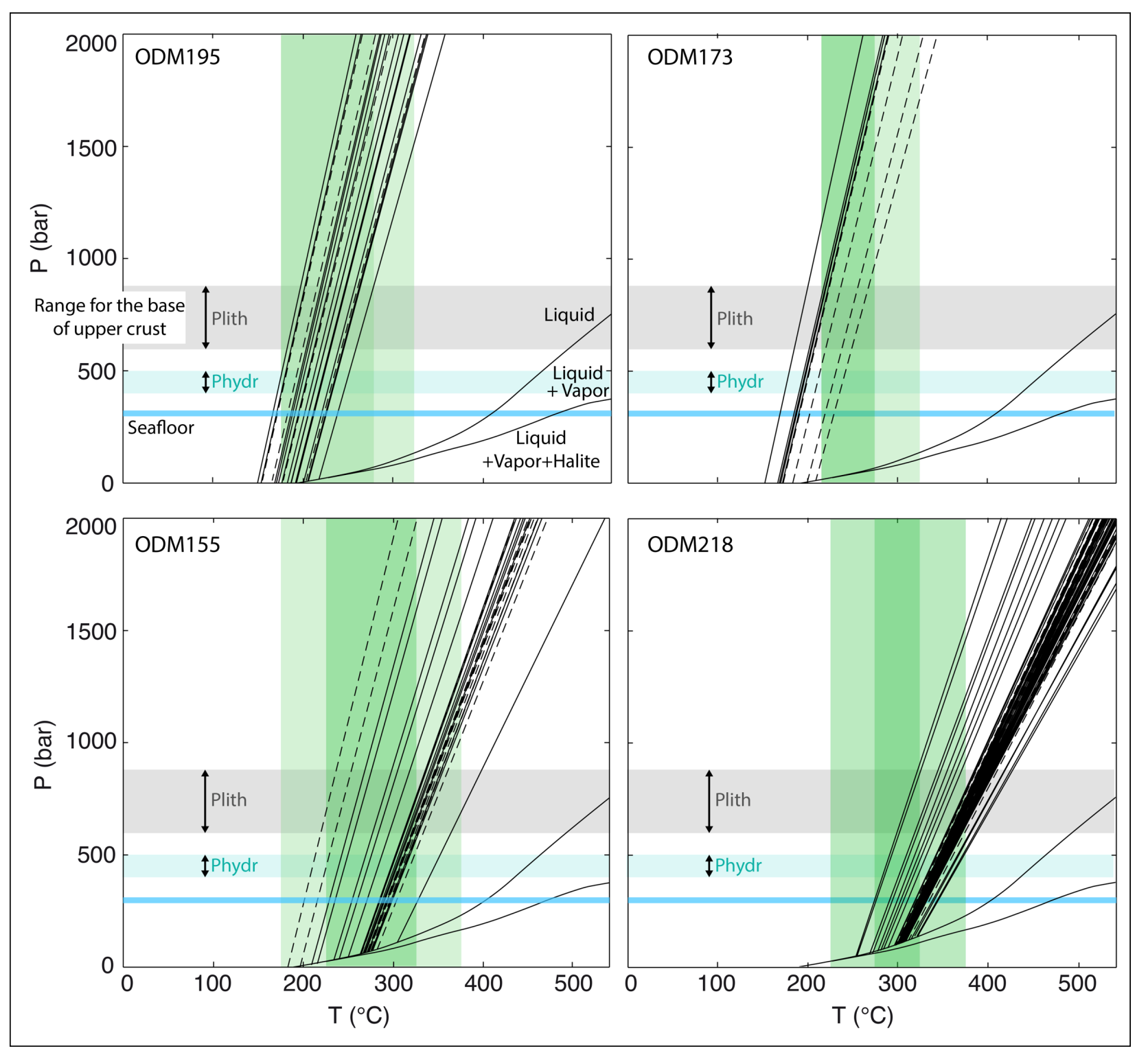

Figure 10: Range of P-T conditions for silicification of brecciated rocks within the detachment plane. P-T isochoric relationships for fluid inclusions, calculated from microthermometric data 1491 (equation of Zhang \& Frantz, 1987), are plotted in black plain and dashed lines for primary and 1492 secondary fluid inclusions respectively. The liquid-vapor and liquid-vapor-halite curves are from 1493 Sourirajan and Kennedy (1962). Pressure at the seafloor is indicated with a blue line, and the range 1494 of lithostatic and hydrostatic fluid pressures at the base of the hangingwall upper crust (1-2 km 1495 thick) is in grey and blue respectively (assuming seawater and rock densities of 1025 and 3000 $1496 \mathrm{~kg} / \mathrm{m}^{3}$ respectively). The temperature range of chlorite crystallization during silicification, calculated from chlorite composition (geothermometer of Bourdelle et al., 2013), is in green (darker 1498 green for higher number of chlorites; see Figure 6d). 


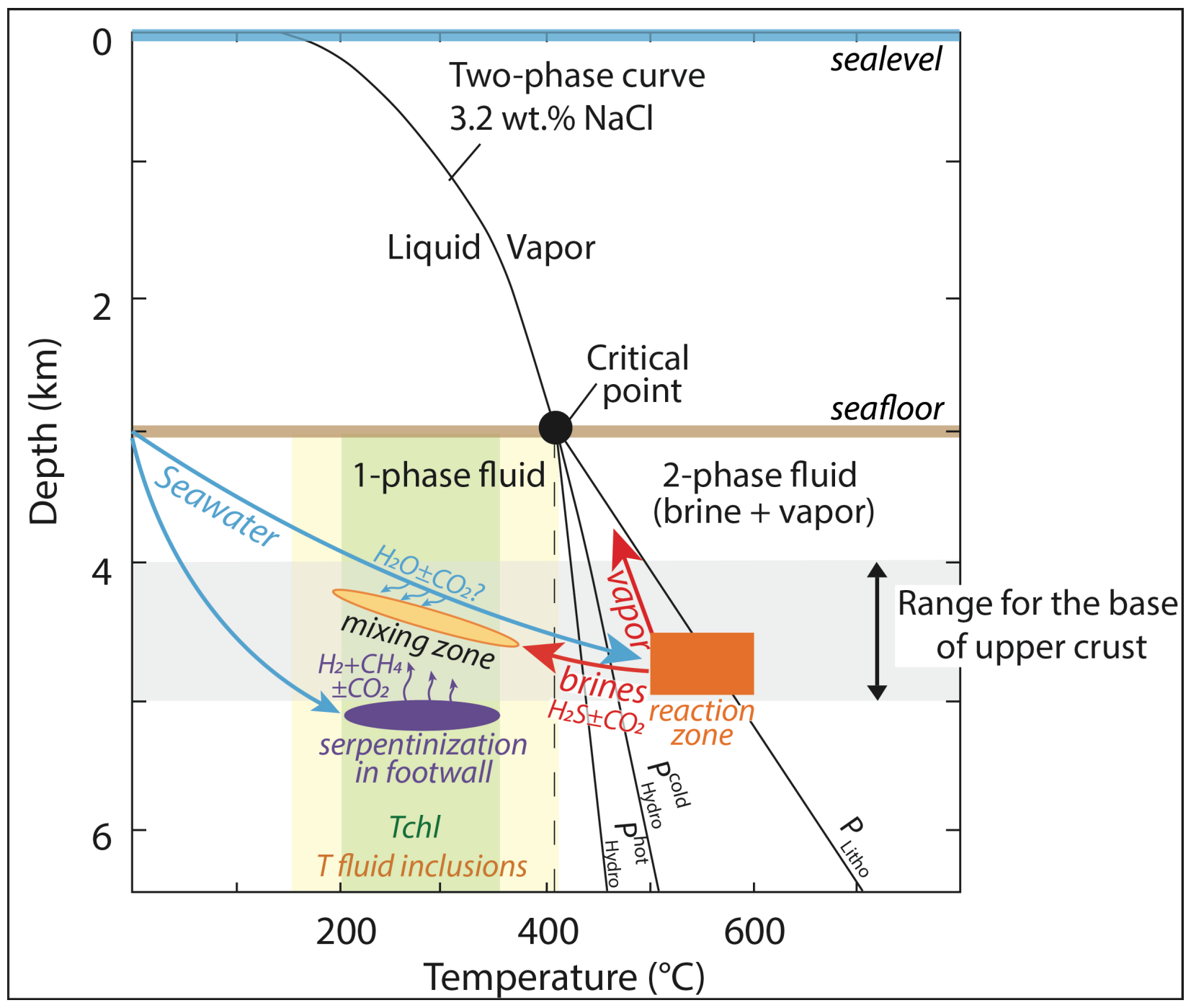

Figure 11: P-T-depth relationships in the $\mathrm{NaCl}-\mathrm{H}_{2} \mathrm{O}$ system for a hydrothermal seawater-like solution $(3.2 \mathrm{wt} \% \mathrm{NaCl})$. The two-phase curve separates the one-phase liquid field from the twophase liquid+vapor field (Sourirajan \& Kennedy, 1962). Temperature-depth relationship for the two-phase curve beyond the critical point $\left(407^{\circ} \mathrm{C}, 298\right.$ bars, black dot) is calculated for both lithostatic and hydrostatic fluid pressures. Cold and hot hydrostatic pressure gradients (100 and 50 $1505 \mathrm{bar} / \mathrm{km}$ respectively) were taken from Coumou et al. (2009) and Castelain et al. (2014). Seawater 1506 (blue arrow) infiltrating the hangingwall crust (1-2 km thick) may undergo phase separation, at 1507 least when reaching the reaction zone (orange rectangle) at the base of the crust (diabase clasts 1508 suggest temperature $>500{ }^{\circ} \mathrm{C}$ ). While part of vapor phases can migrate upwards into the crust, 1509 higher density brines are likely released in the detachment plane upon diabase brecciation (red 1510 arrows). They are mixed in variable amounts with fluids derived from footwall serpentinization 
1511 (purple arrows) and potentially small amounts of seawater circulating in hangingwall basalts (blue 1512 arrows). Temperature ranges of chlorite formation (light green zone) and homogenization of fluid 1513 inclusions (light yellow zone) are reported (see Figures 6d, 8, 10 and text for details).

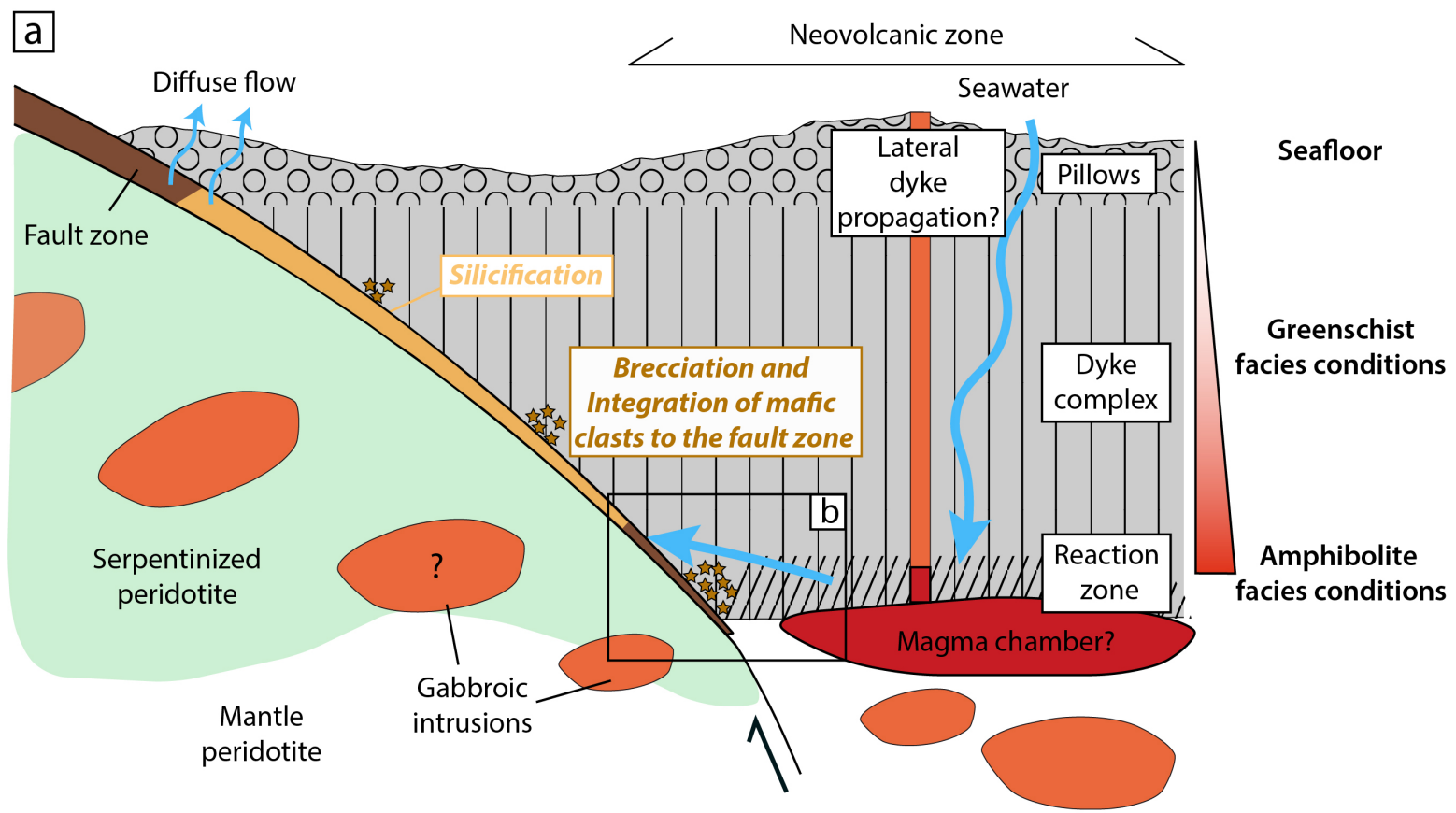

b

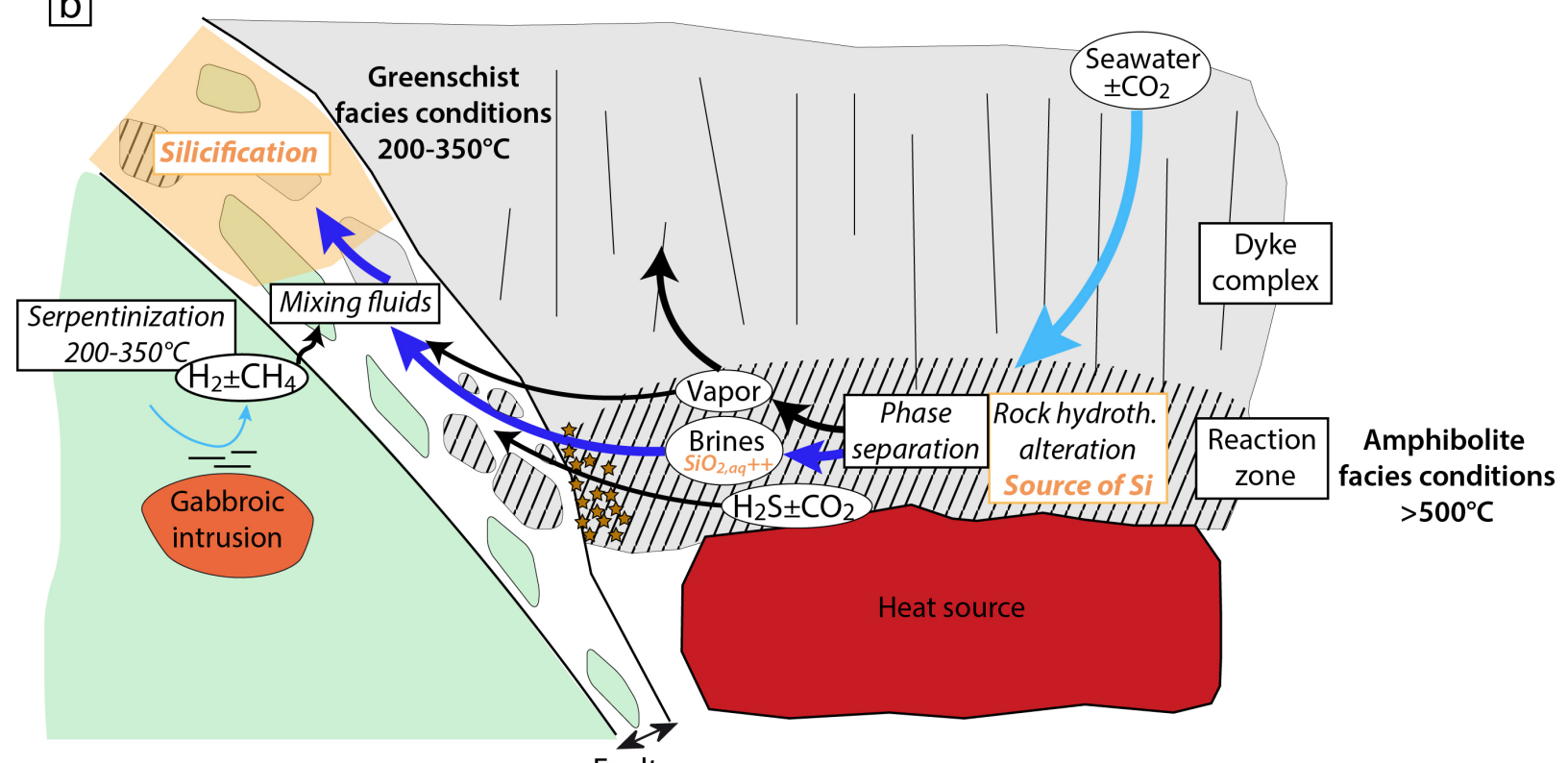

Fault zone

1517 Figure 12: Schematic interpretation of fluid circulation along the $13^{\circ} 20^{\prime} \mathrm{N}$ OCC. (a) The 1518 hangingwall corresponds to a section of upper crust while the footwall progressively exhumes 
1519 material from deeper levels of the lithosphere (mantle-derived peridotites with gabbroic intrusions). 1520 A reaction zone at the base of the upper crust is generated by a heat source located beneath the 1521 neovolcanic zone. The fault zone thickens during exhumation, due to the integration of hangingwall 1522 material. (b) Close up of the reaction zone close to the heat source. Seawater percolates down to 1523 the reaction zone where increased pressure and temperature generate phase separation into brine 1524 and vapor phases. Brines are enriched in silica released by hydrothermal alteration of the mafic 1525 rocks. While most of the vapor phases escape towards the surface, brines (and a small portion of 1526 vapor phases) are integrated into the fault zone during the overplating and mix with (small amounts 1527 of) hydrogen-bearing fluids generated by serpentinization of the footwall. Reaction of hydrogen 1528 with $\mathrm{CO}_{2}$ either dissolved in seawater or released by magmatic activity results in the formation of 1529 methane. As the fluid ascents and cools down, the solubility of silica strongly decreases resulting 1530 in precipitation of quartz that entraps the fluid inclusions. 


\section{QAGUPUBLICATIONS}

Geochemistry, Geophysics, Geosystems

Supporting Information for

\section{inclusions in silicified brecciated fault rocks (Mid-Atlantic Ridge at $13^{\circ} 20^{\prime} \mathrm{N}$ )}

1537
A. Verlaguet ${ }^{1 *}$,
D. Bonnemains ${ }^{2}$,
C. Mével2 , J. Escartín ${ }^{2,3}$, M. Andreani ${ }^{4}$, F. Bourdelle $^{5}$, M-C. Boiron ${ }^{6}$, V. Chavagnac ${ }^{7}$

\footnotetext{
${ }^{1}$ Sorbonne Université, CNRS-INSU, Institut des Sciences de la Terre, ISTeP UMR 7193, F 75005 Paris, France
}

${ }^{2}$ Université de Paris, Institut de Physique du Globe, CNRS, F-75005 Paris, France

${ }^{3}$ Laboratoire de Géologie (CNRS UMR 8538), Département de Géosciences, Ecole Normale Supérieure, PSL University, F-75005 Paris, France

${ }^{4}$ Laboratoire de Géologie LGL-TPE, Université de Lyon, UCBL, ENSL, CNRS, Villeurbanne, 69622, France

${ }^{5}$ Univ. Lille, IMT Lille Douai, Univ. Artois, Yncrea Hauts-de-France, ULR 4515 - LGCgE, Laboratoire de Génie Civil et géo-Environnement, F-59000 Lille, France

${ }^{6}$ Université de Lorraine, CNRS, GeoRessources, F-54000 Nancy, France

${ }^{7}$ Géosciences Environnement Toulouse (GET), Université Paul Sabatier Toulouse 3, CNRS UMR 5563, IRD, Toulouse, France

* Corresponding author: anne.verlaguet@sorbonne-universite.fr

\section{Contents of this file}

Figures $\mathrm{S} 1$ to $\mathrm{S} 5$

Tables S1 to S4 

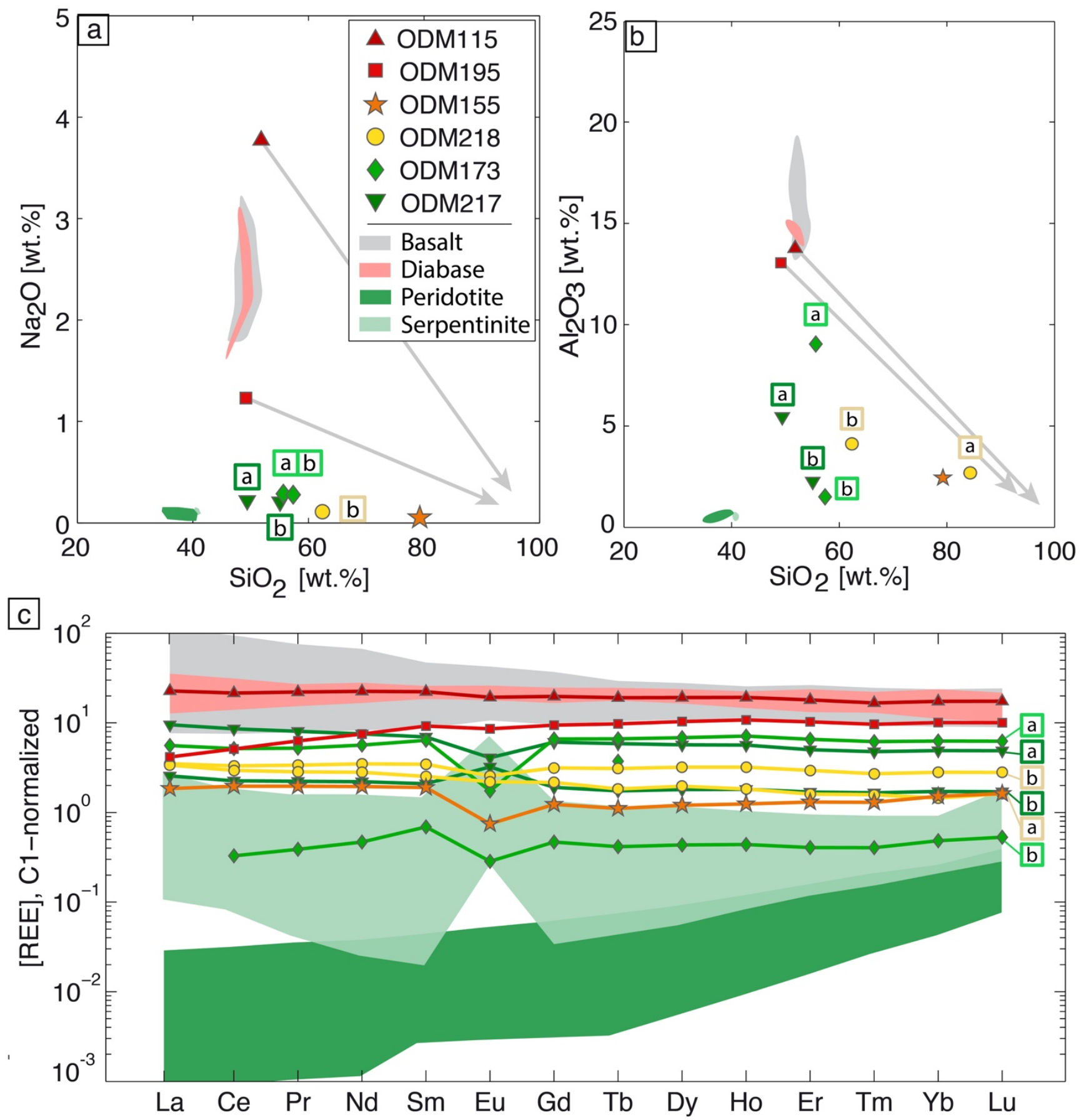

Figure S1: Bulk rock geochemistry. $\mathrm{SiO}_{2}$ versus (a) $\mathrm{Na}_{2} \mathrm{O}$ and (b) $\mathrm{Al}_{2} \mathrm{O}_{3}$; brecciated rocks show a relative decrease in both $\mathrm{Na}_{2} \mathrm{O}$ and $\mathrm{Al}_{2} \mathrm{O}_{3}$ with increasing degree of silicification; grey arrows: trend of passive depletion of $\mathrm{Na}_{2} \mathrm{O}$ and $\mathrm{Al}_{2} \mathrm{O}_{3}$ in breccias due to silica addition. (c) Rare earth element (REE) content of brecciated rocks normalized to chondrite. Compositions are compared to data for basalts and diabases from the $13^{\circ} 20^{\prime} \mathrm{N}$ OCC (Wilson et al., 2013) and for peridotites from the $15^{\circ} 20^{\prime} \mathrm{N}$ Fracture Zone (Godard et al., 2008; Paulick et al., 2006). 

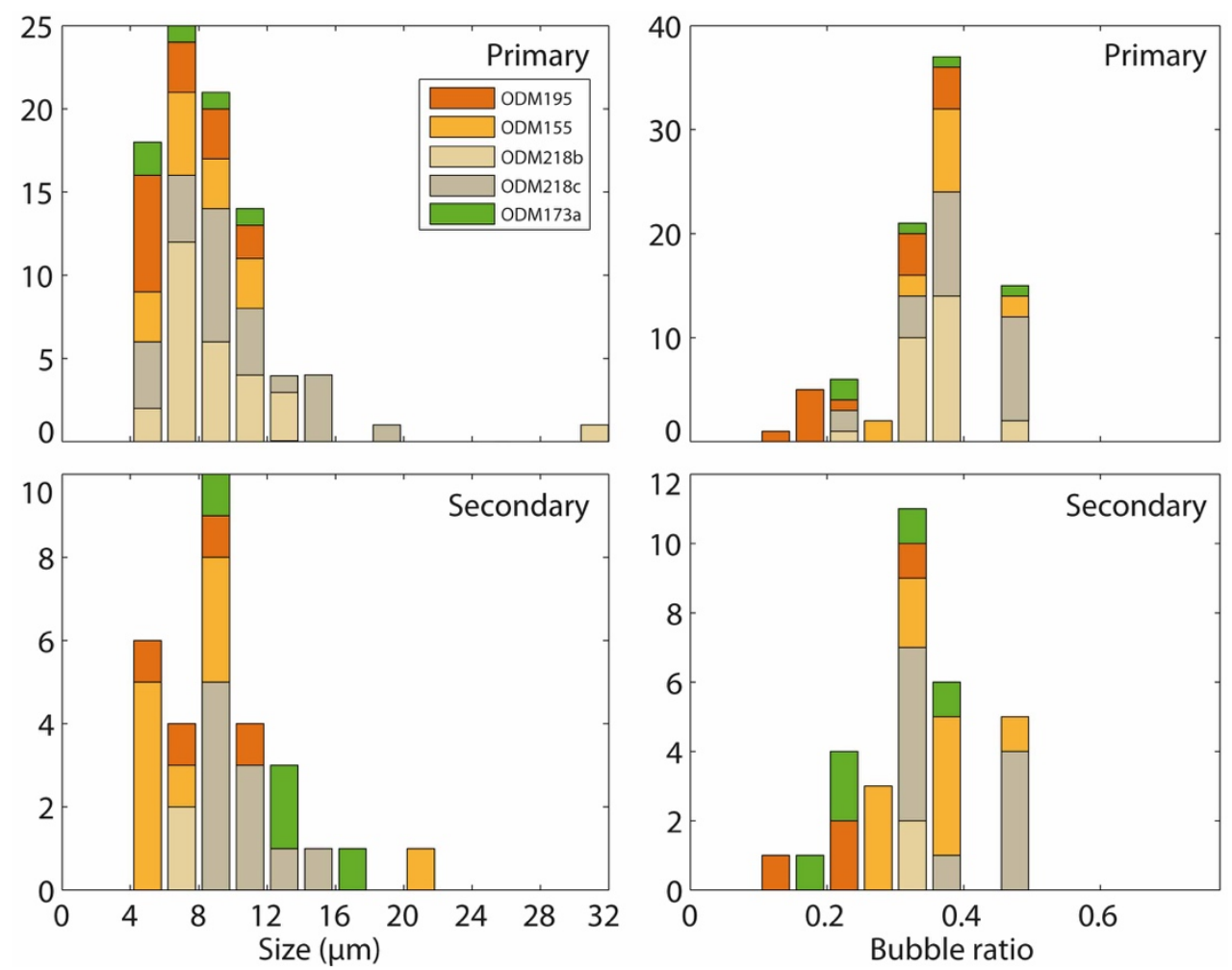

1565

1566 Figure S2: Size distribution (left) and bubble/inclusion volumetric ratio (right) histograms for primary (top) and secondary (bottom) fluid inclusions. Vertical axis is frequency. 


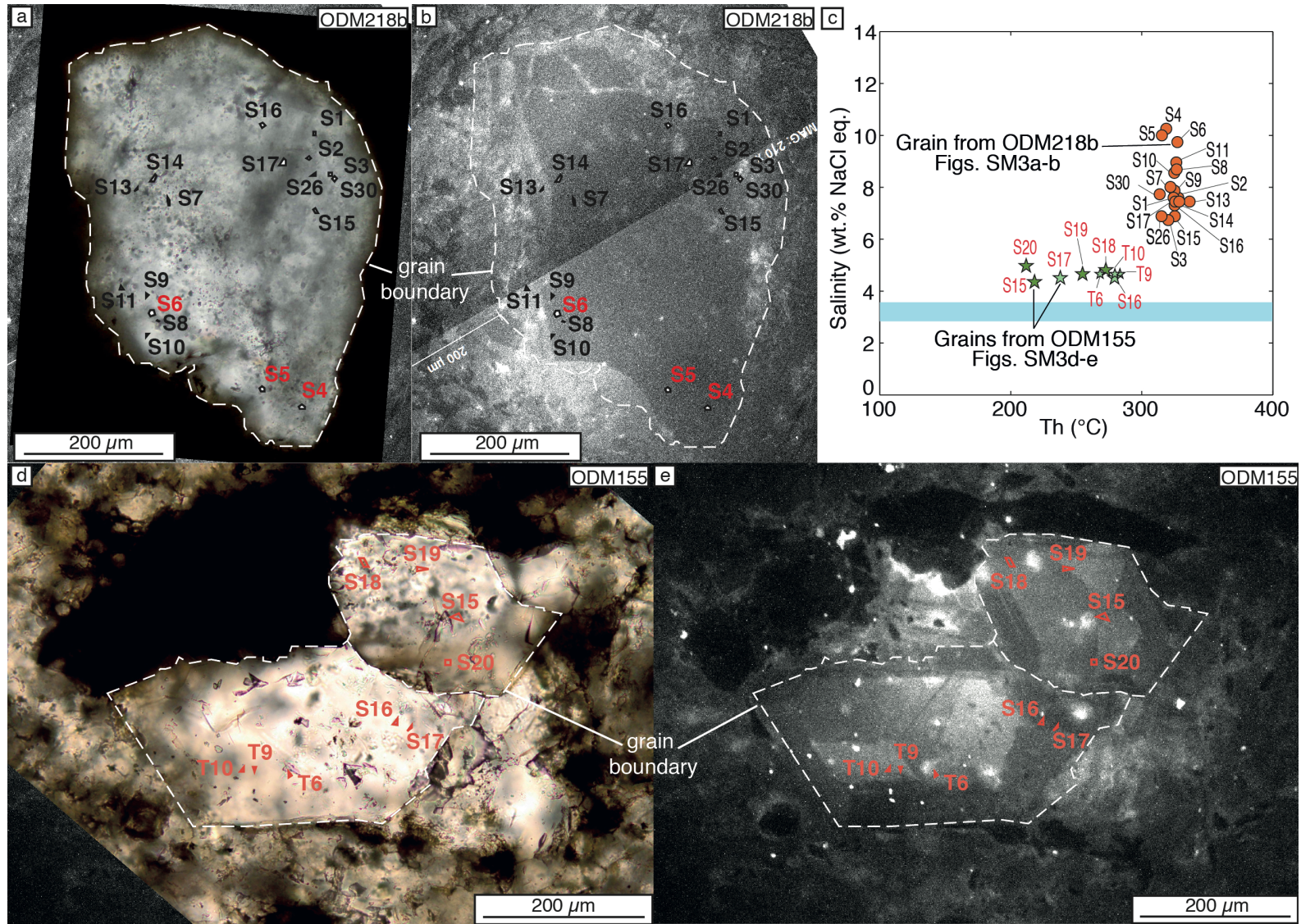

Figure S3: Location of analyzed fluid inclusions in quartz grains from ODM218b ( $a$ and b, orange dots in c) and ODM155 ( $d$ and e, green stars in $\mathrm{c}$ ). Microphotographs under parallel nicols showing individual quartz crystals in ODM218b (a) and in ODM155 (d). SEM-cathodoluminescence images of the same quartz grains in ODM218b (b) and in ODM155 (e); grain boundaries are shown by the white dashed line; luminescence variations illustrate that quartz grains are composed of multiple former quartz angular clasts around which quartz recrystallized in successive generations. Quartz crystallization was unequivocally syntectonic, with successive steps of quartz growth-hydrofracturing-overgrowth. (c) Homogenization temperatures (Th) against salinity (indicated in wt.\% $\mathrm{NaCl}$ equivalent) for primary (big symbols) and secondary (small symbols) fluid inclusions from quartz grains in $\operatorname{ODM} 218 b(a, b)$ and $\operatorname{ODM} 155(d, e)$. Seawater salinity is indicated with a blue line. The large salinity variation measured from fluid inclusions within individual grains indicates entrapment of fluids with varying salinities during successive quartz growth episodes. Note that the position of fluid inclusions was projected on the grain surface, while inclusions are in fact distributed at various depths within the quartz grain. In $\operatorname{ODM} 218 \mathrm{~b}(\mathrm{a}, \mathrm{b})$ inclusions in red are those very close to the thick section surface. 

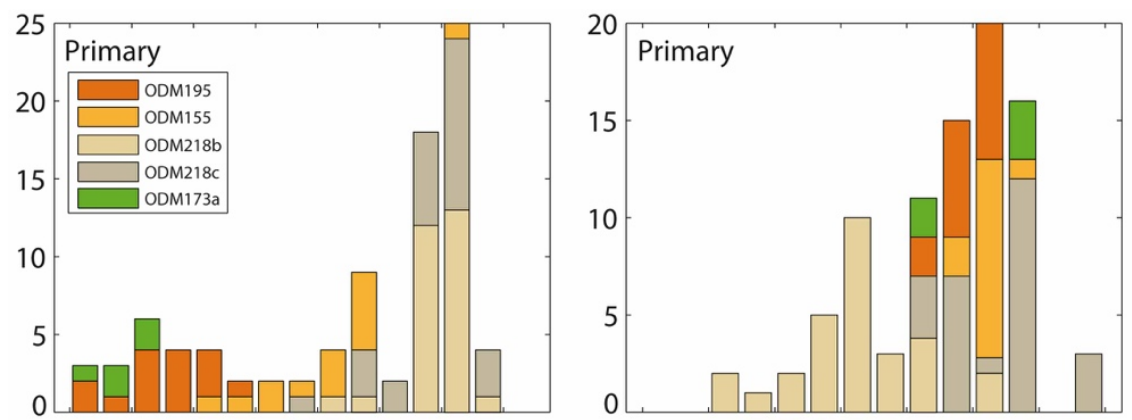

1591
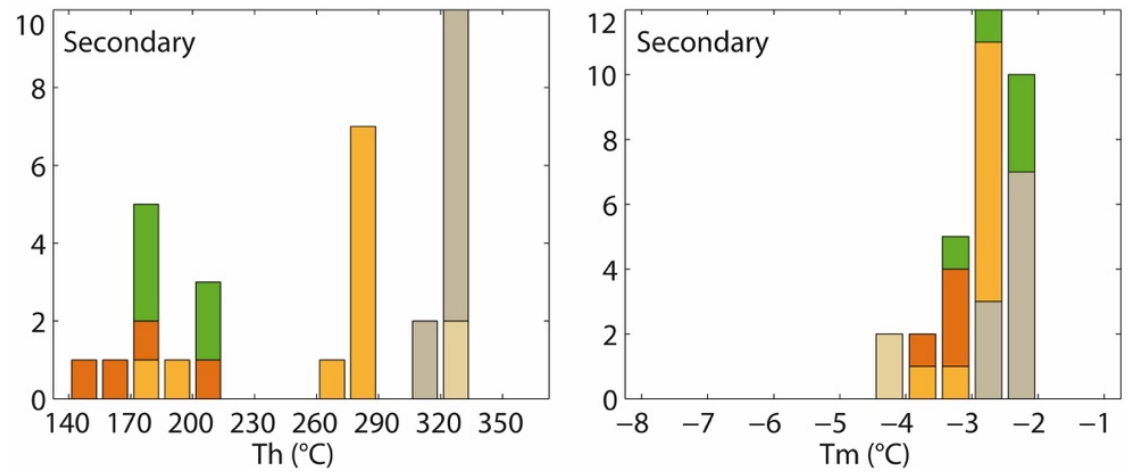

1592

1593

Figure S4: Histogram showing the distribution of homogenization temperatures (Th, left) and ice melting temperatures ( $\mathrm{Tm}_{\mathrm{ice}}$, right) for primary (top) and secondary (bottom) fluid inclusions. Vertical axis is 1595 frequency. 

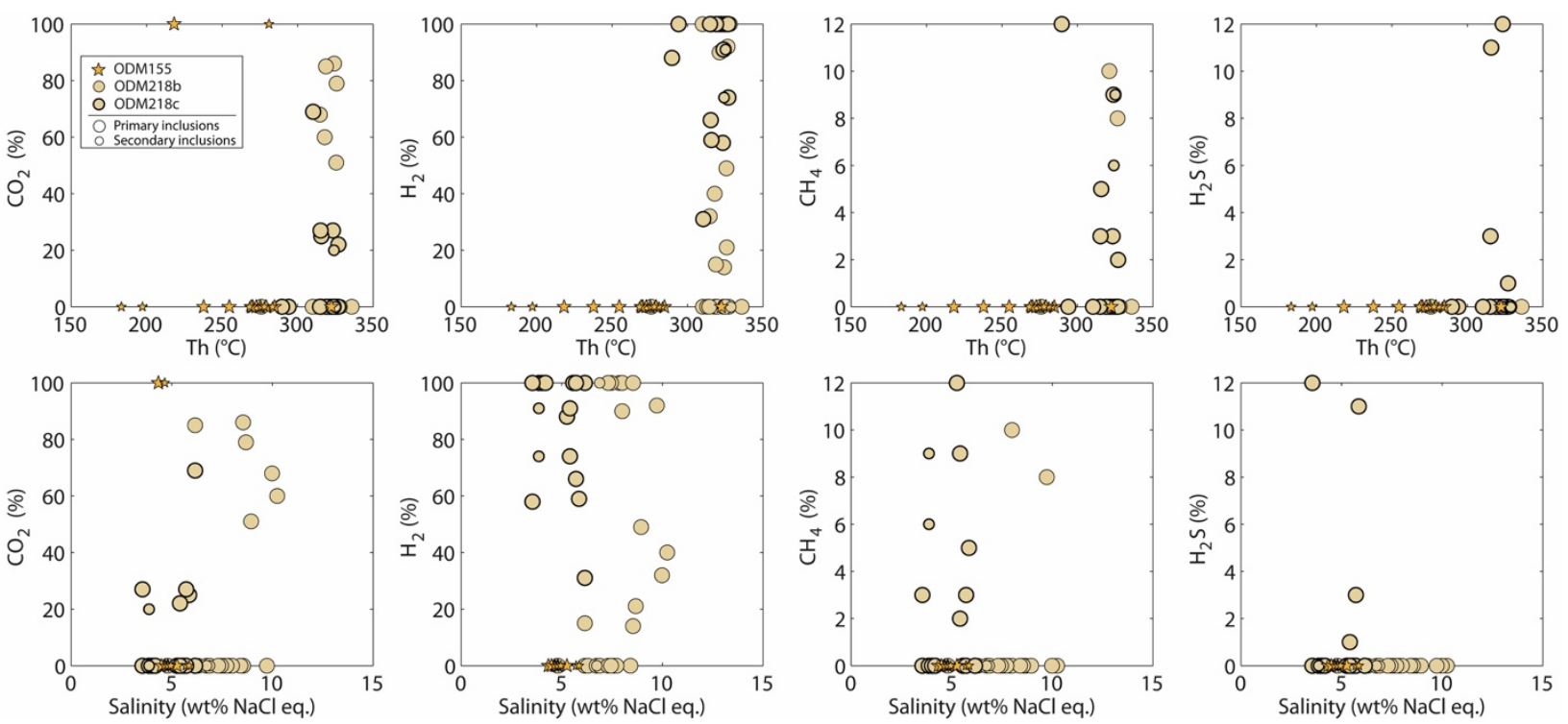

1601 Figure S5: Gas content (mol.\% of gas other than $\mathrm{H}_{2} \mathrm{O}$ in the gas bubble) versus homogenization 1602 temperature (Th) and salinity. 
Table S1. Full chemical analyses of the selected samples.

1604

\begin{tabular}{|c|c|c|c|c|c|c|c|c|c|c|c|c|c|}
\hline \multicolumn{2}{|c|}{$\begin{array}{c}\text { Nature } \\
\text { Degree of silicification } \\
\text { Sample } \\
\end{array}$} & \multirow[t]{2}{*}{$\begin{array}{c}\begin{array}{c}\text { Basaltic clast } \\
\text { Qz free } \\
\text { ODM115 }\end{array} \\
51.81\end{array}$} & \multirow{2}{*}{$\begin{array}{c}\text { Mafic } \\
\begin{array}{c}\text { Moderately Si } \\
\text { ODM195 }\end{array} \\
49.16\end{array}$} & \multirow{2}{*}{$\begin{array}{c}\begin{array}{c}\text { Mafic } \\
\text { Highly Si } \\
\text { ODM218a }\end{array} \\
84.35\end{array}$} & \multirow[t]{2}{*}{$\begin{array}{c}\begin{array}{c}\text { Mafic } \\
\text { Highly Si } \\
\text { ODM218b }\end{array} \\
62.40\end{array}$} & \multirow{2}{*}{$\begin{array}{c}\begin{array}{c}\text { Mafic } \\
\text { Highly Si } \\
\text { ODM218 wr }\end{array} \\
65.72\end{array}$} & \multirow{2}{*}{$\begin{array}{c}\text { Mafic } \\
\text { Highly Si } \\
\text { ODM155 } \\
79.27\end{array}$} & \multirow[t]{2}{*}{$\begin{array}{c}\begin{array}{c}\text { Mixed } \\
\text { Qz free } \\
\text { ODM217a }\end{array} \\
49.41\end{array}$} & \multirow{2}{*}{$\begin{array}{c}\begin{array}{c}\text { Mixed } \\
\text { Qz free } \\
\text { ODM217b }\end{array} \\
55.08\end{array}$} & \multirow{2}{*}{$\begin{array}{c}\begin{array}{c}\text { Mixed } \\
\text { Qz free } \\
\text { ODM217 wr }\end{array} \\
48.90\end{array}$} & \multirow[t]{2}{*}{$\begin{array}{c}\text { Mixed } \\
\text { Moderately Si } \\
\text { ODM173a }\end{array}$} & \multirow[t]{2}{*}{$\begin{array}{c}\text { Mixed } \\
\text { Moderately Si } \\
\text { ODM173b }\end{array}$} & \multirow{2}{*}{$\begin{array}{c}\text { Mixed } \\
\text { Moderately Si } \\
\text { ODM173 wr }\end{array}$} \\
\hline $\mathrm{SiO}_{2}$ & wt.\% & & & & & & & & & & & & \\
\hline $\mathrm{Al}_{2} \mathrm{O}_{3}$ & wt.\% & 13.76 & 13.05 & 2.69 & 4.12 & 3.78 & 2.43 & 5.46 & 2.26 & 5.25 & 9.05 & 1.50 & 5.18 \\
\hline $\mathrm{Fe}_{2} \mathrm{O}_{3}$ & wt.\% & 8.16 & 10.76 & 6.30 & 19.97 & 17.09 & 9.47 & 11.25 & 8.07 & 12.50 & 13.79 & 10.04 & 11.07 \\
\hline $\mathrm{MnO}$ & wt.\% & 0.16 & 0.22 & 0.06 & 0.08 & 0.08 & 0.06 & 0.33 & 0.39 & 0.45 & 0.11 & 0.07 & 0.07 \\
\hline MgO & wt.\% & 6.08 & 11.88 & 2.43 & 4.33 & 4.08 & 2.10 & 22.70 & 22.93 & 21.30 & 11.24 & 20.49 & 8.18 \\
\hline $\mathrm{CaO}$ & wt.\% & 11.27 & 4.57 & 0.28 & 0.48 & 0.30 & 0.28 & 4.32 & 6.72 & 5.33 & 0.24 & 0.09 & 0.17 \\
\hline $\mathrm{Na}_{2} \mathrm{O}$ & wt.\% & 3.78 & 1.23 & $<$ D.L. & 0.11 & 0.07 & 0.05 & 0.22 & 0.20 & 0.24 & 0.29 & 0.28 & 0.17 \\
\hline $\mathrm{K}_{2} \mathrm{O}$ & wt.\% & 0.09 & 0.04 & $<$ D.L. & $<$ D.L. & $<$ D.L. & 0.02 & 0.03 & 0.03 & 0.04 & 0.04 & 0.03 & 0.03 \\
\hline $\mathrm{TiO}_{2}$ & wt.\% & 1.37 & 0.65 & 0.17 & 0.27 & 0.26 & 0.15 & 0.42 & 0.12 & 0.40 & 0.49 & < D.L. & 0.26 \\
\hline $\mathrm{P}_{2} \mathrm{O}_{5}$ & wt.\% & 0.16 & $<$ D.L. & < D.L. & < D.L. & $<$ D.L. & $<$ D.L. & 0.06 & $<$ D.L. & 0.05 & 0.05 & < D.L. & 0.04 \\
\hline PF & wt.\% & 3.03 & 7.22 & 3.44 & 7.72 & 7.77 & 6.67 & 6.39 & 4.86 & 6.52 & 9.18 & 10.28 & 6.24 \\
\hline Total & wt.\% & 99.65 & 98.79 & 99.71 & 99.48 & 99.14 & 100.49 & 100.60 & 100.67 & 100.97 & 100.11 & 100.15 & 99.66 \\
\hline Mg \# & & 59.61 & 68.62 & 43.26 & 30.05 & 32.11 & 30.51 & 80.00 & 84.91 & 77.15 & 61.74 & 80.18 & 59.41 \\
\hline $\mathrm{FeO}$ & wt.\% & 4.74 & 5.54 & 5.50 & 14.46 & 12.49 & 3.51 & 8.01 & 5.61 & 8.85 & 7.45 & 5.75 & 6.14 \\
\hline $\mathrm{H}_{2} \mathrm{O}$ total & wt.\% & 3.22 & 8.13 & 2.49 & 4.20 & 4.32 & 2.62 & 7.05 & 5.55 & 6.95 & 8.93 & < D.L. & 5.32 \\
\hline S total & wt.\% & 0.04 & 0.04 & 1.04 & 7.68 & 6.21 & 4.75 & 0.02 & 0.03 & 0.02 & 0.66 & 0.69 & 1.98 \\
\hline B & $\mathrm{ppm}$ & 5 & 2 & 2 & $<<2$ & $<2$ & 4 & 11 & 8 & 14 & 8 & 10 & 7 \\
\hline $\mathrm{Cl}$ & ppm & 230 & 800 & 240 & 355 & 295 & 235 & 435 & 380 & 580 & 1520 & 2540 & 1030 \\
\hline $\mathbf{L i}$ & $\mathrm{ppm}$ & 3.7 & 7.6 & 5.4 & 3.0 & 3.3 & 8.3 & 7.4 & 7.6 & 7.4 & 4.3 & 4.2 & 3.1 \\
\hline As & $\mathrm{ppm}$ & 2.29 & $<$ D.L. & < D.L. & < D.L. & < D.L. & 1.80 & 1.88 & 1.75 & 3.25 & 1.68 & < D.L. & < D.L. \\
\hline $\mathrm{Ba}$ & ppm & 35.37 & 4.17 & 3.00 & 1.67 & < D.L. & 2.66 & < D.L. & 1.69 & < D.L. & 1.90 & < D.L. & 6.75 \\
\hline $\mathrm{Be}$ & $\mathrm{ppm}$ & 0.64 & $<$ D.L. & < D.L. & < D.L. & < D.L. & < D.L. & 0.46 & 0.60 & 0.50 & < D.L. & < D.L. & < D.L. \\
\hline $\mathrm{Bi}$ & ppm & 0.19 & $<$ D.L. & 0.21 & 0.69 & 1.30 & 0.32 & < D.L. & < D.L. & 0.10 & 0.12 & 0.52 & 0.20 \\
\hline $\mathrm{Cd}$ & ppm & 0.14 & $<$ D.L. & < D.L. & < D.L. & 0.12 & < D.L. & < D.L. & < D.L. & < D.L. & 0.68 & 203.80 & 12.18 \\
\hline $\mathrm{Ce}$ & $\mathrm{ppm}$ & 13.19 & 3.13 & 1.81 & 2.03 & 1.98 & 1.20 & 5.26 & 1.38 & 3.77 & 3.17 & 0.20 & 1.35 \\
\hline Co & ppm & 30.87 & 31.10 & 36.76 & 206.20 & 151.30 & 82.21 & 71.51 & 61.76 & 71.78 & 49.51 & 280.50 & 60.67 \\
\hline $\mathrm{Cr}$ & ppm & 308.50 & 349.30 & 293.70 & 590.40 & 525.60 & 303.30 & 1826.00 & 1895.00 & 2070.00 & 934.30 & 3319.00 & 1214.00 \\
\hline Cs & ppm & < D.L. & < D.L. & < D.L. & < D.L. & < D.L. & < D.L. & < D.L. & < D.L. & < D.L. & < D.L. & < D.L. & < D.L. \\
\hline $\mathrm{Cu}$ & $\mathrm{ppm}$ & 66.84 & 11.68 & 87.36 & 564.10 & 697.30 & 19.05 & 874.20 & 450.80 & 1540.00 & 504.20 & 1609.00 & 605.20 \\
\hline Dy & $\mathrm{ppm}$ & 4.72 & 2.55 & 0.48 & 0.79 & 0.75 & 0.30 & 1.40 & 0.44 & 1.38 & 1.68 & 0.11 & 0.92 \\
\hline $\mathrm{Er}$ & ppm & 2.89 & 1.65 & 0.26 & 0.47 & 0.45 & 0.21 & 0.80 & 0.27 & 0.81 & 1.05 & 0.07 & 0.59 \\
\hline Eu & ppm & 1.09 & 0.48 & 0.12 & 0.14 & 0.13 & 0.04 & 0.23 & 0.18 & 0.19 & 0.10 & 0.02 & 0.05 \\
\hline Ga & ppm & 13.96 & 11.95 & 3.46 & 5.99 & 5.77 & 3.93 & 8.09 & 4.23 & 8.36 & 11.42 & 5.84 & 7.08 \\
\hline Gd & ppm & 3.93 & 1.88 & 0.43 & 0.63 & 0.60 & 0.25 & 1.21 & 0.38 & 1.12 & 1.32 & 0.09 & 0.75 \\
\hline Ge & ppm & 1.85 & 0.75 & 0.50 & 0.43 & 0.40 & 0.28 & 1.57 & 1.64 & 1.95 & 0.61 & 5.09 & 0.74 \\
\hline $\mathrm{Hf}$ & ppm & 2.45 & 0.97 & 0.27 & 0.48 & 0.45 & 0.28 & 0.75 & 0.22 & 0.68 & 0.75 & < D.L. & 0.39 \\
\hline Ho & $\mathrm{ppm}$ & 1.05 & 0.59 & 0.10 & 0.18 & 0.16 & 0.07 & 0.31 & 0.10 & 0.30 & 0.39 & 0.02 & 0.22 \\
\hline In & $\mathrm{ppm}$ & <D.L. & $<$ D.L. & < D.L. & < D.L. & < D.L. & < D.L. & 0.11 & < D.L. & 0.18 & < D.L. & < D.L. & < D.L. \\
\hline La & ppm & 5.40 & 0.99 & 0.80 & 0.83 & 0.83 & 0.44 & 2.26 & 0.61 & 1.55 & 1.33 & < D.L. & 0.55 \\
\hline Lu & $\mathrm{ppm}$ & 0.43 & 0.25 & 0.04 & 0.07 & 0.07 & 0.04 & 0.12 & 0.04 & 0.12 & 0.15 & 0.01 & 0.09 \\
\hline Mo & ppm & < D.L. & < D.L. & 5.58 & 12.11 & 8.58 & 1.43 & < D.L. & $<$ D.L. & < D.L. & 1.39 & 184.30 & 14.06 \\
\hline
\end{tabular}




\begin{tabular}{|c|c|c|c|c|c|c|c|c|c|c|c|c|c|}
\hline $\mathrm{Nb}$ & ppm & 6.84 & 0.57 & 1.08 & 1.46 & 1.47 & 0.89 & 3.90 & 0.88 & 2.96 & 2.07 & $<$ D.L. & 1.16 \\
\hline $\mathrm{Nd}$ & $\mathrm{ppm}$ & 10.30 & 3.43 & 1.28 & 1.60 & 1.52 & 0.89 & 3.45 & 1.01 & 2.69 & 2.59 & 0.21 & 1.20 \\
\hline $\mathrm{Ni}$ & $\mathrm{ppm}$ & 112.80 & 126.40 & 140.40 & 492.70 & 385.90 & 190.70 & 1080.00 & 1180.00 & 1064.00 & 429.50 & 1609.00 & 710.70 \\
\hline $\mathbf{P b}$ & $\mathrm{ppm}$ & 0.90 & <D.L. & < D.L. & 1.23 & 1.17 & 1.08 & < D.L. & < D.L. & < D.L. & < D.L. & 2.24 & 1.22 \\
\hline $\mathrm{Pr}$ & ppm & 2.05 & 0.58 & 0.26 & 0.31 & 0.29 & 0.18 & 0.75 & 0.21 & 0.56 & 0.49 & 0.04 & 0.20 \\
\hline $\mathbf{R b}$ & $\mathrm{ppm}$ & 0.79 & $<$ D.L. & $<$ D.L. & $<$ D.L. & $<$ D.L. & $<$ D.L. & $<$ D.L. & $<$ D.L. & $<$ D.L. & $<$ D.L. & $<$ D.L. & $<$ D.L. \\
\hline Sc & $\mathrm{ppm}$ & 38.58 & 32.40 & 5.40 & 8.67 & 8.67 & 5.12 & 15.97 & 9.30 & 16.01 & 22.31 & 9.47 & 12.85 \\
\hline Sb & ppm & < D.L. & <D.L. & < D.L. & < D.L. & < D.L. & < D.L. & $<$ D.L. & < D.L. & < D.L. & < D.L. & 0.25 & $<$ D.L. \\
\hline Sm & $\mathrm{ppm}$ & 3.30 & 1.36 & 0.37 & 0.51 & 0.50 & 0.28 & 1.03 & 0.31 & 0.90 & 0.95 & 0.10 & 0.50 \\
\hline Sn & $\mathrm{ppm}$ & 1.55 & 0.64 & 3.80 & 0.48 & 0.52 & 9.66 & < D.L. & < D.L. & 0.54 & 0.79 & 0.83 & 1.09 \\
\hline $\mathrm{Sr}$ & $\mathrm{ppm}$ & 145.50 & 32.01 & < D.L. & 4.17 & < D.L. & 3.86 & 5.94 & 4.84 & 6.93 & 9.61 & 4.48 & 6.18 \\
\hline Ta & ppm & 0.52 & 0.05 & 0.09 & 0.11 & 0.11 & 0.07 & 0.28 & 0.06 & 0.21 & 0.16 & < D.L. & 0.08 \\
\hline Tb & $\mathrm{ppm}$ & 0.69 & 0.35 & 0.07 & 0.11 & 0.11 & 0.04 & 0.21 & 0.06 & 0.20 & 0.24 & 0.02 & 0.14 \\
\hline Th & $\mathrm{ppm}$ & 0.55 & < D.L. & < D.L. & 0.12 & 0.11 & 0.07 & 0.29 & 0.07 & 0.23 & 0.16 & $<$ D.L. & 0.08 \\
\hline $\mathrm{Tm}$ & ppm & 0.41 & 0.24 & 0.04 & 0.07 & 0.06 & 0.03 & 0.12 & 0.04 & 0.12 & 0.15 & 0.01 & 0.08 \\
\hline $\mathbf{U}$ & $\mathrm{ppm}$ & 0.19 & < D.L. & 0.07 & 0.07 & 0.06 & 0.05 & 0.13 & 0.07 & 0.15 & 0.14 & 0.45 & 0.14 \\
\hline v & $\mathrm{ppm}$ & 266.50 & 180.50 & 35.06 & 58.83 & 54.12 & 34.71 & 99.12 & 49.06 & 99.92 & 115.90 & 42.02 & 68.29 \\
\hline $\mathbf{w}$ & ppm & 0.32 & < D.L. & 0.72 & < D.L. & < D.L. & 0.55 & 0.32 & < D.L. & 0.41 & 1.28 & < D.L. & 1.21 \\
\hline $\mathbf{Y}$ & $\mathrm{ppm}$ & 26.89 & 14.83 & 2.43 & 4.39 & 4.12 & 1.91 & 7.95 & 2.65 & 7.71 & 10.34 & 0.61 & 5.87 \\
\hline $\mathrm{Yb}$ & $\mathrm{ppm}$ & 2.80 & 1.63 & 0.23 & 0.45 & 0.43 & 0.24 & 0.79 & 0.28 & 0.80 & 1.01 & 0.08 & 0.57 \\
\hline $\mathrm{Zn}$ & ppm & 60.02 & 105.60 & 45.73 & 56.51 & 64.18 & 33.78 & 139.50 & 115.00 & 161.80 & 237.90 & 2947.00 & 379.70 \\
\hline $\mathrm{Zr}$ & $\mathrm{ppm}$ & 84.25 & 29.36 & 10.77 & 17.07 & 16.19 & 10.14 & 27.35 & 7.70 & 24.15 & 24.61 & $<$ D.L. & 14.00 \\
\hline
\end{tabular}

\section{6}


Table S2. Chemical analysis (wt.\%) and structural formulas of chlorite, and calculated temperature of formation.

\begin{tabular}{|c|c|c|c|c|c|c|c|c|c|c|c|c|c|c|c|c|c|c|c|c|c|c|c|}
\hline $\begin{array}{c}\text { Sample } \\
\text { Clast vs matrix } \\
\text { Analysis \# }\end{array}$ & $\begin{array}{c}195 \\
\text { Clast } \\
5 / 1\end{array}$ & $\begin{array}{l}195 \\
\text { Clast } \\
6 / 1\end{array}$ & $\begin{array}{l}195 \\
\text { Clast } \\
9 / 1\end{array}$ & $\begin{array}{c}195 \\
\text { Clast } \\
10 / 1\end{array}$ & $\begin{array}{c}195 \\
\text { Clast } \\
29 / 1\end{array}$ & $\begin{array}{c}195 \\
\text { Clast } \\
31 / 1\end{array}$ & $\begin{array}{c}195 \\
\text { Clast } \\
34 / 1\end{array}$ & $\begin{array}{l}195 \\
\text { Clast } \\
36 / 1\end{array}$ & $\begin{array}{c}195 \\
\text { Clast } \\
37 / 1\end{array}$ & $\begin{array}{c}195 \\
\text { Mat } \\
12 / 1\end{array}$ & $\begin{array}{c}195 \\
\text { Mat } \\
15 / 1\end{array}$ & $\begin{array}{c}195 \\
\text { Mat } \\
24 / 1\end{array}$ & $\begin{array}{c}195 \\
\text { Mat } \\
27 / 1\end{array}$ & $\begin{array}{l}195 \\
\text { Mat } \\
2 / 1\end{array}$ & $\begin{array}{l}195 \\
\text { Mat } \\
3 / 1\end{array}$ & $\begin{array}{l}195 \\
\text { Mat } \\
4 / 1 .\end{array}$ & $\begin{array}{l}195 \\
\text { Mat } \\
5 / 1\end{array}$ & $\begin{array}{l}195 \\
\text { Mat } \\
7 / 1\end{array}$ & $\begin{array}{l}195 \\
\text { Mat } \\
8 / 1 .\end{array}$ & $\begin{array}{l}195 \\
\text { Mat } \\
9 / 1\end{array}$ & $\begin{array}{c}195 \\
\text { Mat } \\
10 / 1\end{array}$ & $\begin{array}{c}195 \\
\text { Mat } \\
11 / 1\end{array}$ & $\begin{array}{r}195 \\
\text { Mat } \\
12 / 1\end{array}$ \\
\hline \multicolumn{24}{|l|}{ Chlorite composition ${ }^{a}$} \\
\hline $\mathrm{SiO}_{2}$ & 28.30 & 28.08 & 29.32 & 29.98 & 30.82 & 29.17 & 28.24 & 28.74 & 30.86 & 29.18 & 29.87 & 29.07 & 29.23 & 31.32 & 29.51 & 30.67 & 30.05 & 30.82 & 30.91 & 30.18 & 30.26 & 31.25 & 30.98 \\
\hline $\mathrm{TiO}_{2}$ & 0.01 & 0.04 & 0.02 & 0.00 & 0.01 & 0.01 & 0.06 & 0.00 & 0.02 & 0.01 & 0.00 & 0.00 & 0.08 & 0.02 & 0.00 & 0.00 & 0.04 & 0.00 & 0.04 & 0.00 & 0.01 & 0.02 & 0.02 \\
\hline $\mathrm{Al}_{2} \mathrm{O}_{3}$ & 19.56 & 19.77 & 18.45 & 18.28 & 17.94 & 18.94 & 20.21 & 19.39 & 17.39 & 19.45 & 19.06 & 19.14 & 18.93 & 18.64 & 18.77 & 17.80 & 17.65 & 18.54 & 17.51 & 18.48 & 17.67 & 17.83 & 18.10 \\
\hline $\mathrm{Cr}_{2} \mathrm{O}_{3}$ & 0.00 & 0.00 & 0.00 & 0.00 & 0.01 & 0.00 & 0.06 & 0.05 & 0.00 & 0.00 & 0.00 & 0.07 & 0.00 & 0.00 & 0.00 & 0.01 & 0.01 & 0.03 & 0.08 & 0.03 & 0.04 & 0.04 & 0.00 \\
\hline $\mathrm{FeO}$ & 18.76 & 18.44 & 16.25 & 15.57 & 16.08 & 16.45 & 15.93 & 15.62 & 14.80 & 16.77 & 16.88 & 16.86 & 16.09 & 14.84 & 14.91 & 15.42 & 16.29 & 14.63 & 14.77 & 15.25 & 14.64 & 15.73 & 14.73 \\
\hline $\mathrm{MnO}$ & 0.49 & 0.37 & 0.32 & 0.25 & 0.39 & 0.38 & 0.19 & 0.23 & 0.31 & 0.43 & 0.38 & 0.35 & 0.36 & 0.35 & 0.42 & 0.37 & 0.44 & 0.34 & 0.39 & 0.33 & 0.46 & 0.37 & 0.39 \\
\hline MgO & 19.38 & 19.96 & 22.28 & 22.99 & 22.03 & 21.12 & 22.20 & 22.85 & 23.26 & 21.70 & 21.47 & 21.86 & 21.58 & 23.24 & 22.82 & 21.58 & 21.48 & 23.53 & 22.65 & 23.16 & 23.04 & 22.40 & 23.21 \\
\hline $\mathrm{NiO}$ & 0.07 & 0.00 & 0.02 & 0.04 & 0.02 & 0.07 & 0.01 & 0.00 & 0.04 & 0.02 & 0.12 & 0.01 & 0.05 & 0.00 & 0.06 & 0.05 & 0.02 & 0.07 & 0.03 & 0.02 & 0.00 & 0.05 & 0.05 \\
\hline $\mathrm{CaO}$ & 0.05 & 0.07 & 0.19 & 0.10 & 0.14 & 0.14 & 0.09 & 0.05 & 0.11 & 0.14 & 0.15 & 0.14 & 0.20 & 0.21 & 0.16 & 0.25 & 0.21 & 0.16 & 0.25 & 0.16 & 0.20 & 0.23 & 0.20 \\
\hline $\mathrm{Na}_{2} \mathrm{O}$ & 0.05 & 0.02 & 0.11 & 0.06 & 0.05 & 0.05 & 0.02 & 0.03 & 0.05 & 0.02 & 0.03 & 0.04 & 0.05 & 0.06 & 0.06 & 0.03 & 0.07 & 0.08 & 0.08 & 0.05 & 0.10 & 0.09 & 0.07 \\
\hline $\mathrm{K}_{2} \mathrm{O}$ & 0.00 & 0.02 & 0.05 & 0.06 & 0.05 & 0.04 & 0.03 & 0.02 & 0.03 & 0.01 & 0.03 & 0.02 & 0.04 & 0.06 & 0.05 & 0.06 & 0.13 & 0.08 & 0.10 & 0.05 & 0.06 & 0.09 & 0.06 \\
\hline total & 86.68 & 86.77 & 87.00 & 87.32 & 87.54 & 86.37 & 87.04 & 86.97 & 86.87 & 87.74 & 87.99 & 87.54 & 86.62 & 88.73 & 86.75 & 86.26 & 86.40 & 88.30 & 86.80 & 87.72 & 86.48 & 88.09 & 87.82 \\
\hline $\mathrm{K}_{2} \mathrm{O}+\mathrm{Na}_{2} \mathrm{O}+\mathrm{CaO}$ & 0.10 & 0.11 & 0.35 & 0.21 & 0.24 & 0.23 & 0.14 & 0.10 & 0.19 & 0.17 & 0.21 & 0.20 & 0.29 & 0.32 & 0.27 & 0.34 & 0.42 & 0.32 & 0.43 & 0.26 & 0.36 & 0.41 & 0.33 \\
\hline \multicolumn{24}{|l|}{ Structural formula ${ }^{b}$} \\
\hline $\mathrm{Si}$ & 2.91 & 2.87 & 2.96 & 3.00 & 3.08 & 2.97 & 2.84 & 2.89 & 3.09 & 2.92 & 2.98 & 2.92 & 2.96 & 3.06 & 2.96 & 3.10 & 3.05 & 3.03 & 3.10 & 3.00 & 3.04 & 3.09 & 3.06 \\
\hline $\mathrm{Ti}$ & 0.00 & 0.00 & 0.00 & 0.00 & 0.00 & 0.00 & 0.00 & 0.00 & 0.00 & 0.00 & 0.00 & 0.00 & 0.01 & 0.00 & 0.00 & 0.00 & 0.00 & 0.00 & 0.00 & 0.00 & 0.00 & 0.00 & 0.00 \\
\hline Al & 2.37 & 2.38 & 2.19 & 2.15 & 2.11 & 2.27 & 2.40 & 2.30 & 2.05 & 2.30 & 2.24 & 2.27 & 2.26 & 2.15 & 2.22 & 2.12 & 2.11 & 2.15 & 2.07 & 2.16 & 2.10 & 2.08 & 2.11 \\
\hline Alv $^{\mathrm{IV}}$ & 1.09 & 1.13 & 1.04 & 1.00 & 0.92 & 1.03 & 1.16 & 1.11 & 0.91 & 1.08 & 1.02 & 1.08 & 1.04 & 0.94 & 1.04 & 0.90 & 0.95 & 0.97 & 0.90 & 1.00 & 0.96 & 0.91 & 0.94 \\
\hline $\mathbf{A l}^{\mathrm{VI}}$ & 1.27 & 1.26 & 1.15 & 1.15 & 1.19 & 1.24 & 1.24 & 1.19 & 1.13 & 1.22 & 1.23 & 1.19 & 1.22 & 1.21 & 1.19 & 1.22 & 1.17 & 1.18 & 1.16 & 1.16 & 1.14 & 1.18 & 1.17 \\
\hline $\mathrm{Cr}$ & 0.00 & 0.00 & 0.00 & 0.00 & 0.00 & 0.00 & 0.00 & 0.00 & 0.00 & 0.00 & 0.00 & 0.01 & 0.00 & 0.00 & 0.00 & 0.00 & 0.00 & 0.00 & 0.01 & 0.00 & 0.00 & 0.00 & 0.00 \\
\hline $\mathrm{Fe}$ & 1.61 & 1.58 & 1.37 & 1.30 & 1.34 & 1.40 & 1.34 & 1.31 & 1.24 & 1.41 & 1.41 & 1.42 & 1.36 & 1.21 & 1.25 & 1.30 & 1.38 & 1.20 & 1.24 & 1.27 & 1.23 & 1.30 & 1.22 \\
\hline $\mathrm{Mn}$ & 0.04 & 0.03 & 0.03 & 0.02 & 0.03 & 0.03 & 0.02 & 0.02 & 0.03 & 0.04 & 0.03 & 0.03 & 0.03 & 0.03 & 0.04 & 0.03 & 0.04 & 0.03 & 0.03 & 0.03 & 0.04 & 0.03 & 0.03 \\
\hline Mg & 2.97 & 3.05 & 3.35 & 3.43 & 3.28 & 3.20 & 3.33 & 3.43 & 3.47 & 3.24 & 3.20 & 3.28 & 3.26 & 3.39 & 3.42 & 3.25 & 3.25 & 3.45 & 3.38 & 3.43 & 3.46 & 3.31 & 3.42 \\
\hline $\mathbf{N i}$ & 0.01 & 0.00 & 0.00 & 0.00 & 0.00 & 0.01 & 0.00 & 0.00 & 0.00 & 0.00 & 0.01 & 0.00 & 0.00 & 0.00 & 0.00 & 0.00 & 0.00 & 0.01 & 0.00 & 0.00 & 0.00 & 0.00 & 0.00 \\
\hline $\mathrm{Ca}$ & 0.01 & 0.01 & 0.02 & 0.01 & 0.01 & 0.02 & 0.01 & 0.00 & 0.01 & 0.01 & 0.02 & 0.01 & 0.02 & 0.02 & 0.02 & 0.03 & 0.02 & 0.02 & 0.03 & 0.02 & 0.02 & 0.02 & 0.02 \\
\hline $\mathrm{Na}$ & 0.01 & 0.00 & 0.02 & 0.01 & 0.01 & 0.01 & 0.00 & 0.01 & 0.01 & 0.00 & 0.01 & 0.01 & 0.01 & 0.01 & 0.01 & 0.01 & 0.01 & 0.02 & 0.01 & 0.01 & 0.02 & 0.02 & 0.01 \\
\hline K & 0.00 & 0.00 & 0.01 & 0.01 & 0.01 & 0.01 & 0.00 & 0.00 & 0.00 & 0.00 & 0.00 & 0.00 & 0.01 & 0.01 & 0.01 & 0.01 & 0.02 & 0.01 & 0.01 & 0.01 & 0.01 & 0.01 & 0.01 \\
\hline octaedral sum & 5.91 & 5.93 & 5.95 & 5.93 & 5.87 & 5.91 & 5.95 & 5.96 & 5.89 & 5.93 & 5.90 & 5.95 & 5.91 & 5.87 & 5.93 & 5.85 & 5.90 & 5.91 & 5.88 & 5.93 & 5.92 & 5.87 & 5.89 \\
\hline vacancies & 0.09 & 0.07 & 0.05 & 0.07 & 0.13 & 0.09 & 0.05 & 0.04 & 0.11 & 0.07 & 0.10 & 0.05 & 0.09 & 0.13 & 0.07 & 0.15 & 0.10 & 0.09 & 0.12 & 0.07 & 0.08 & 0.13 & 0.11 \\
\hline $\mathrm{Mg} \#^{\mathrm{c}}$ & 0.65 & 0.66 & 0.71 & 0.72 & 0.71 & 0.70 & 0.71 & 0.72 & 0.74 & 0.70 & 0.69 & 0.70 & 0.71 & 0.74 & 0.73 & 0.71 & 0.70 & 0.74 & 0.73 & 0.73 & 0.74 & 0.72 & 0.74 \\
\hline $\mathbf{R}^{2+d}$ & 4.63 & 4.66 & 4.75 & 4.75 & 4.66 & 4.64 & 4.69 & 4.76 & 4.73 & 4.69 & 4.65 & 4.72 & 4.65 & 4.63 & 4.71 & 4.59 & 4.68 & 4.69 & 4.65 & 4.73 & 4.73 & 4.64 & 4.68 \\
\hline \multicolumn{24}{|l|}{ Calculated $\mathrm{T}\left({ }^{\circ} \mathrm{C}\right)$} \\
\hline $\begin{array}{l}\text { Bourdelle et al. }(2013)^{e} \\
\text { Tcorrected }\left(>350^{\circ} \mathrm{C}\right)^{e}\end{array}$ & 261 & 300 & 318 & 269 & 197 & 238 & $\begin{array}{l}373 \\
324\end{array}$ & $\begin{array}{l}393 \\
332\end{array}$ & 210 & 282 & 230 & 321 & 248 & 198 & 273 & 178 & 217 & 228 & 196 & 260 & 241 & 192 & 209 \\
\hline
\end{tabular}

1610

1611

1612

1613

a EPMA analysis of chlorite composition in wt.\% of oxides, selected if oxide sum is in the $86-89$ wt.\% range and $\mathrm{Na}_{2} \mathrm{O}+\mathrm{K}_{2} \mathrm{O}+\mathrm{CaO}<1$ wt.\%

${ }^{b}$ Chlorite structural formula calculated on a 14-oxygen basis. Selection criterias: $\mathrm{Si} \leq 4$, cation sum $\leq 10.1$ and vacancies $>0.01$

${ }^{\mathrm{c}} \mathrm{Mg} \#=\mathrm{Mg} /(\mathrm{Mg}+\mathrm{Fe})$

${ }^{d} R^{2+}=(\mathrm{Fe}+\mathrm{Mg}+\mathrm{Mn}+\mathrm{Ni})$ 
$1614{ }^{\mathrm{e}}$ temperature of chlorite formation calculated from $\mathrm{R}^{2+}$ and Si with the thermometer of Bourdelle et al. (2013) calibrated for Tchl $<350{ }^{\circ} \mathrm{C}$; a quadratic

1615 correction is applied for Tchl $>350^{\circ} \mathrm{C}$ (Tcorrected)

1616

\begin{tabular}{|c|c|c|c|c|c|c|c|c|c|c|c|c|c|c|c|c|c|c|c|c|c|c|c|}
\hline Sample & 195 & 195 & 195 & 195 & 195 & 195 & 195 & 195 & 195 & 195 & 195 & 195 & 195 & 195 & 195 & 195 & 195 & 195 & 195 & 195 & 195 & 195 & 195 \\
\hline Clast vs matrix & Mat & Mat & Mat & Mat & Mat & Mat & Mat & Mat & Mat & Mat & Mat & Mat & Mat & Mat & Mat & Mat & Mat & Mat & Mat & Mat & Mat & Mat & Mat \\
\hline Analysis \# & $13 / 1$ & $17 / 1$ & $18 / 1$ & $19 / 1$ & $20 / 1$ & $21 / 1$ & $22 / 1$ & $23 / 1$ & $24 / 1$ & $25 / 1$ & $26 / 1$ & $28 / 1$ & $30 / 1$ & $31 / 1$ & $32 / 1$ & $33 / 1$ & $34 / 1$ & $35 / 1$ & $36 / 1$ & $37 / 1$ & $38 / 1$ & $39 / 1$ & $40 / 1$ \\
\hline \multicolumn{24}{|c|}{ Chlorite composition a } \\
\hline $\mathrm{SiO}_{2}$ & 30.06 & 30.55 & 30.97 & 30.15 & 31.84 & 30.68 & 30.56 & 31.26 & 30.86 & 30.25 & 30.44 & 30.43 & 31.32 & 30.78 & 29.48 & 29.68 & 29.70 & 30.14 & 28.72 & 29.06 & 29.12 & 29.76 & 29.65 \\
\hline $\mathrm{TiO}_{2}$ & 0.02 & 0.01 & 0.01 & 0.02 & 0.03 & 0.04 & 0.00 & 0.04 & 0.00 & 0.02 & 0.08 & 0.00 & 0.00 & 0.00 & 0.00 & 0.00 & 0.02 & 0.00 & 0.07 & 0.04 & 0.00 & 0.02 & 0.07 \\
\hline $\mathrm{Al}_{2} \mathrm{O}_{3}$ & 18.67 & 18.30 & 17.70 & 17.85 & 18.36 & 17.95 & 18.30 & 17.65 & 18.58 & 18.66 & 18.48 & 17.69 & 17.71 & 18.17 & 18.76 & 18.91 & 18.65 & 18.16 & 19.05 & 19.18 & 18.94 & 18.71 & 18.58 \\
\hline $\mathrm{Cr}_{2} \mathrm{O}_{3}$ & 0.04 & 0.01 & 0.04 & 0.07 & 0.01 & 0.02 & 0.02 & 0.00 & 0.00 & 0.08 & 0.01 & 0.05 & 0.00 & 0.01 & 0.04 & 0.01 & 0.01 & 0.00 & 0.00 & 0.04 & 0.03 & 0.00 & 0.00 \\
\hline $\mathrm{FeO}$ & 14.62 & 13.98 & 15.61 & 14.03 & 15.44 & 14.95 & 14.36 & 15.08 & 13.67 & 14.59 & 14.52 & 14.41 & 14.23 & 13.18 & 17.42 & 16.90 & 17.56 & 16.12 & 17.77 & 17.01 & 18.17 & 17.79 & 15.36 \\
\hline MnO & 0.45 & 0.29 & 0.44 & 0.23 & 0.45 & 0.38 & 0.29 & 0.41 & 0.42 & 0.23 & 0.36 & 0.31 & 0.38 & 0.31 & 0.30 & 0.37 & 0.40 & 0.40 & 0.34 & 0.43 & 0.40 & 0.43 & 0.31 \\
\hline MgO & 22.47 & 24.25 & 21.86 & 23.75 & 21.73 & 22.86 & 23.18 & 22.53 & 24.23 & 24.82 & 22.99 & 24.49 & 23.73 & 25.12 & 21.68 & 21.72 & 22.16 & 22.11 & 21.80 & 21.58 & 20.68 & 20.87 & 22.73 \\
\hline $\mathrm{NiO}$ & 0.03 & 0.12 & 0.06 & 0.08 & 0.03 & 0.00 & 0.05 & 0.00 & 0.01 & 0.13 & 0.00 & 0.08 & 0.10 & 0.01 & 0.04 & 0.03 & 0.01 & 0.00 & 0.01 & 0.04 & 0.01 & 0.06 & 0.01 \\
\hline $\mathrm{CaO}$ & 0.24 & 0.19 & 0.17 & 0.13 & 0.33 & 0.26 & 0.27 & 0.30 & 0.06 & 0.10 & 0.15 & 0.13 & 0.17 & 0.11 & 0.14 & 0.13 & 0.12 & 0.21 & 0.08 & 0.10 & 0.15 & 0.17 & 0.14 \\
\hline $\mathrm{Na}_{2} \mathrm{O}$ & 0.02 & 0.03 & 0.05 & 0.03 & 0.03 & 0.04 & 0.06 & 0.04 & 0.06 & 0.05 & 0.05 & 0.02 & 0.06 & 0.06 & 0.04 & 0.02 & 0.06 & 0.07 & 0.00 & 0.02 & 0.02 & 0.01 & 0.05 \\
\hline $\mathrm{K}_{2} \mathrm{O}$ & 0.05 & 0.01 & 0.06 & 0.03 & 0.09 & 0.04 & 0.04 & 0.06 & 0.05 & 0.02 & 0.02 & 0.05 & 0.06 & 0.05 & 0.02 & 0.04 & 0.03 & 0.07 & 0.03 & 0.02 & 0.04 & 0.06 & 0.03 \\
\hline total & 86.68 & 87.73 & 86.96 & 86.39 & 88.34 & 87.22 & 87.13 & 87.36 & 87.95 & 88.96 & 87.09 & 87.67 & 87.75 & 87.79 & 87.93 & 87.81 & 88.71 & 87.29 & 87.86 & 87.51 & 87.54 & 87.87 & 86.95 \\
\hline $\mathrm{K}_{2} \mathrm{O}+\mathrm{Na}_{2} \mathrm{O}+\mathrm{CaO}$ & 0.31 & 0.23 & 0.28 & 0.20 & 0.46 & 0.34 & 0.37 & 0.39 & 0.17 & 0.17 & 0.21 & 0.20 & 0.28 & 0.21 & 0.20 & 0.19 & 0.20 & 0.36 & 0.11 & 0.13 & 0.20 & 0.24 & 0.22 \\
\hline \multicolumn{24}{|l|}{ Structural formula ${ }^{b}$} \\
\hline $\mathrm{Si}$ & 3.01 & 3.01 & 3.11 & 3.02 & 3.13 & 3.06 & 3.04 & 3.11 & 3.03 & 2.96 & 3.03 & 3.02 & 3.09 & 3.02 & 2.96 & 2.97 & 2.96 & 3.02 & 2.89 & 2.93 & 2.95 & 2.99 & 2.98 \\
\hline $\mathrm{Ti}$ & 0.00 & 0.00 & 0.00 & 0.00 & 0.00 & 0.00 & 0.00 & 0.00 & 0.00 & 0.00 & 0.01 & 0.00 & 0.00 & 0.00 & 0.00 & 0.00 & 0.00 & 0.00 & 0.01 & 0.00 & 0.00 & 0.00 & 0.01 \\
\hline Al & 2.21 & 2.13 & 2.09 & 2.11 & 2.13 & 2.11 & 2.15 & 2.07 & 2.15 & 2.15 & 2.17 & 2.07 & 2.06 & 2.10 & 2.22 & 2.23 & 2.19 & 2.15 & 2.26 & 2.28 & 2.26 & 2.22 & 2.20 \\
\hline $\mathrm{Al}^{\mathrm{IV}}$ & 0.99 & 0.99 & 0.89 & 0.98 & 0.87 & 0.94 & 0.96 & 0.89 & 0.97 & 1.04 & 0.97 & 0.98 & 0.91 & 0.98 & 1.04 & 1.03 & 1.04 & 0.98 & 1.11 & 1.07 & 1.05 & 1.01 & 1.02 \\
\hline$A I^{V I}$ & 1.22 & 1.14 & 1.20 & 1.13 & 1.26 & 1.17 & 1.19 & 1.18 & 1.18 & 1.10 & 1.20 & 1.08 & 1.15 & 1.12 & 1.18 & 1.20 & 1.14 & 1.17 & 1.15 & 1.20 & 1.21 & 1.21 & 1.17 \\
\hline $\mathrm{Cr}$ & 0.00 & 0.00 & 0.00 & 0.01 & 0.00 & 0.00 & 0.00 & 0.00 & 0.00 & 0.01 & 0.00 & 0.00 & 0.00 & 0.00 & 0.00 & 0.00 & 0.00 & 0.00 & 0.00 & 0.00 & 0.00 & 0.00 & 0.00 \\
\hline $\mathrm{Fe}$ & 1.23 & 1.15 & 1.31 & 1.18 & 1.27 & 1.25 & 1.20 & 1.26 & 1.12 & 1.19 & 1.21 & 1.19 & 1.17 & 1.08 & 1.46 & 1.41 & 1.46 & 1.35 & 1.50 & 1.43 & 1.54 & 1.50 & 1.29 \\
\hline $\mathrm{Mn}$ & 0.04 & 0.02 & 0.04 & 0.02 & 0.04 & 0.03 & 0.02 & 0.03 & 0.03 & 0.02 & 0.03 & 0.03 & 0.03 & 0.03 & 0.03 & 0.03 & 0.03 & 0.03 & 0.03 & 0.04 & 0.03 & 0.04 & 0.03 \\
\hline Mg & 3.36 & 3.57 & 3.27 & 3.55 & 3.19 & 3.40 & 3.44 & 3.34 & 3.54 & 3.62 & 3.41 & 3.62 & 3.49 & 3.68 & 3.24 & 3.24 & 3.29 & 3.31 & 3.27 & 3.24 & 3.12 & 3.13 & 3.40 \\
\hline $\mathrm{Ni}$ & 0.00 & 0.01 & 0.00 & 0.01 & 0.00 & 0.00 & 0.00 & 0.00 & 0.00 & 0.01 & 0.00 & 0.01 & 0.01 & 0.00 & 0.00 & 0.00 & 0.00 & 0.00 & 0.00 & 0.00 & 0.00 & 0.01 & 0.00 \\
\hline $\mathrm{Ca}$ & 0.03 & 0.02 & 0.02 & 0.01 & 0.04 & 0.03 & 0.03 & 0.03 & 0.01 & 0.01 & 0.02 & 0.01 & 0.02 & 0.01 & 0.01 & 0.01 & 0.01 & 0.02 & 0.01 & 0.01 & 0.02 & 0.02 & 0.02 \\
\hline $\mathrm{Na}$ & 0.00 & 0.01 & 0.01 & 0.01 & 0.01 & 0.01 & 0.01 & 0.01 & 0.01 & 0.01 & 0.01 & 0.00 & 0.01 & 0.01 & 0.01 & 0.00 & 0.01 & 0.01 & 0.00 & 0.00 & 0.00 & 0.00 & 0.01 \\
\hline $\mathrm{K}$ & 0.01 & 0.00 & 0.01 & 0.00 & 0.01 & 0.00 & 0.00 & 0.01 & 0.01 & 0.00 & 0.00 & 0.01 & 0.01 & 0.01 & 0.00 & 0.01 & 0.00 & 0.01 & 0.00 & 0.00 & 0.00 & 0.01 & 0.00 \\
\hline octaedral sum & 5.88 & 5.92 & 5.85 & 5.92 & 5.81 & 5.89 & 5.89 & 5.86 & 5.91 & 5.97 & 5.88 & 5.95 & 5.89 & 5.94 & 5.94 & 5.92 & 5.95 & 5.91 & 5.97 & 5.93 & 5.93 & 5.90 & 5.92 \\
\hline vacancies & 0.12 & 0.08 & 0.15 & 0.08 & 0.19 & 0.11 & 0.11 & 0.14 & 0.09 & 0.03 & 0.12 & 0.05 & 0.11 & 0.06 & 0.06 & 0.08 & 0.05 & 0.09 & 0.03 & 0.07 & 0.07 & 0.10 & 0.08 \\
\hline Mg\# ${ }^{c}$ & 0.73 & 0.76 & 0.71 & 0.75 & 0.71 & 0.73 & 0.74 & 0.73 & 0.76 & 0.75 & 0.74 & 0.75 & 0.75 & 0.77 & 0.69 & 0.70 & 0.69 & 0.71 & 0.69 & 0.69 & 0.67 & 0.68 & 0.73 \\
\hline$R^{2+d}$ & 4.62 & 4.75 & 4.62 & 4.75 & 4.49 & 4.68 & 4.66 & 4.63 & 4.70 & 4.84 & 4.65 & 4.84 & 4.70 & 4.78 & 4.73 & 4.69 & 4.78 & 4.70 & 4.80 & 4.71 & 4.69 & 4.67 & 4.72 \\
\hline \multirow{2}{*}{\multicolumn{24}{|c|}{$\frac{\text { Calculated T }\left({ }^{\circ} \mathrm{C}\right)}{\text { urdelle et al. }(2013}$}} \\
\hline & & & & & & & & & & & & & & & & & & & & & & & \\
\hline
\end{tabular}




\begin{tabular}{|c|c|c|c|c|c|c|c|c|c|c|c|c|c|c|c|c|c|c|c|c|c|c|c|}
\hline $\begin{array}{c}\text { Sample } \\
\text { Clast vs matrix } \\
\text { Analysis \# }\end{array}$ & $\begin{array}{c}155 \\
\text { Clast } \\
14\end{array}$ & $\begin{array}{l}155 \\
\text { Clast } \\
73 / 1\end{array}$ & $\begin{array}{c}155 \\
\text { Clast } \\
75 / 1\end{array}$ & $\begin{array}{c}155 \\
\text { Clast } \\
76 / 1\end{array}$ & $\begin{array}{c}155 \\
\text { Clast } \\
77 / 1\end{array}$ & $\begin{array}{c}155 \\
\text { Clast } \\
81 / 1\end{array}$ & $\begin{array}{c}155 \\
\text { Clast } \\
82 / 1\end{array}$ & $\begin{array}{c}155 \\
\text { Clast } \\
83 / 1\end{array}$ & $\begin{array}{c}155 \\
\text { Clast } \\
41 / 1 \\
\end{array}$ & $\begin{array}{c}155 \\
\text { Clast } \\
42 / 1 \\
\end{array}$ & $\begin{array}{c}155 \\
\text { Clast } \\
43 / 1 \\
\end{array}$ & $\begin{array}{c}155 \\
\text { Clast } \\
44 / 1\end{array}$ & $\begin{array}{c}155 \\
\text { Clast } \\
45 / 1\end{array}$ & $\begin{array}{c}155 \\
\text { Clast } \\
46 / 1 \\
\end{array}$ & $\begin{array}{c}155 \\
\text { Clast } \\
48 / 1\end{array}$ & $\begin{array}{c}155 \\
\text { Clast } \\
49 / 1\end{array}$ & $\begin{array}{c}155 \\
\text { Clast } \\
50 / 1\end{array}$ & $\begin{array}{c}155 \\
\text { Clast } \\
51 / 1\end{array}$ & $\begin{array}{c}155 \\
\text { Clast } \\
52 / 1\end{array}$ & $\begin{array}{c}155 \\
\text { Clast } \\
53 / 1\end{array}$ & $\begin{array}{c}155 \\
\text { Clast } \\
54 / 1\end{array}$ & $\begin{array}{c}155 \\
\text { Clast } \\
57 / 1\end{array}$ & $\begin{array}{c}155 \\
\text { Clast } \\
58 / 1\end{array}$ \\
\hline \multicolumn{24}{|l|}{ Chlorite composition a } \\
\hline $\mathrm{SiO}_{2}$ & 28.07 & 31.03 & 30.61 & 30.78 & 30.68 & 29.35 & 27.02 & 29.24 & 27.94 & 28.79 & 26.59 & 26.61 & 25.39 & 28.07 & 29.40 & 29.06 & 28.72 & 27.25 & 29.02 & 28.86 & 29.17 & 27.82 & 26.49 \\
\hline $\mathrm{TiO}_{2}$ & 0.03 & 0.04 & 0.08 & 0.06 & 0.03 & 0.01 & 0.07 & 0.02 & 0.00 & 0.02 & 0.05 & 0.06 & 0.02 & 0.01 & 0.00 & 0.04 & 0.09 & 0.07 & 0.00 & 0.01 & 0.01 & 0.05 & 0.05 \\
\hline $\mathrm{Al}_{2} \mathrm{O}_{3}$ & 19.16 & 19.99 & 18.27 & 20.81 & 18.41 & 17.26 & 19.23 & 17.37 & 18.57 & 18.11 & 19.93 & 19.88 & 18.88 & 18.00 & 18.17 & 18.03 & 17.80 & 19.41 & 17.68 & 18.03 & 17.46 & 20.26 & 20.36 \\
\hline $\mathrm{Cr}_{2} \mathrm{O}_{3}$ & 0.03 & 0.08 & 0.01 & 0.00 & 0.06 & 0.00 & 0.10 & 0.02 & 0.11 & 0.21 & 0.08 & 0.04 & 0.00 & 0.08 & 0.26 & 0.40 & 0.44 & 0.04 & 0.31 & 0.43 & 0.30 & 0.12 & 0.00 \\
\hline $\mathrm{FeO}$ & 22.98 & 19.31 & 19.62 & 19.95 & 20.75 & 22.31 & 24.31 & 21.62 & 22.64 & 24.05 & 25.12 & 25.55 & 29.02 & 21.98 & 21.13 & 21.07 & 22.37 & 24.60 & 22.35 & 22.81 & 22.68 & 24.06 & 25.08 \\
\hline Mno & 0.27 & 0.35 & 0.31 & 0.53 & 0.33 & 0.32 & 0.39 & 0.24 & 0.23 & 0.41 & 0.24 & 0.29 & 0.17 & 0.52 & 0.56 & 0.52 & 0.38 & 0.39 & 0.33 & 0.35 & 0.21 & 0.21 & 0.32 \\
\hline MgO & 17.21 & 15.68 & 17.35 & 14.91 & 15.33 & 18.53 & 16.82 & 18.95 & 17.08 & 16.84 & 15.17 & 15.82 & 12.40 & 18.19 & 17.25 & 16.60 & 17.12 & 15.04 & 16.17 & 16.74 & 16.60 & 15.22 & 14.27 \\
\hline $\mathrm{NiO}$ & 0.09 & 0.09 & 0.07 & 0.15 & 0.12 & 0.11 & 0.00 & 0.09 & 0.14 & 0.08 & 0.00 & 0.01 & 0.03 & 0.09 & 0.01 & 0.17 & 0.08 & 0.05 & 0.07 & 0.17 & 0.06 & 0.00 & 0.02 \\
\hline $\mathrm{CaO}$ & 0.09 & 0.18 & 0.22 & 0.23 & 0.30 & 0.22 & 0.06 & 0.09 & 0.07 & 0.10 & 0.07 & 0.07 & 0.07 & 0.10 & 0.11 & 0.11 & 0.09 & 0.05 & 0.27 & 0.13 & 0.18 & 0.08 & 0.11 \\
\hline $\mathrm{Na}_{2} \mathrm{O}$ & 0.01 & 0.08 & 0.06 & 0.08 & 0.11 & 0.01 & 0.06 & 0.04 & 0.00 & 0.03 & 0.04 & 0.07 & 0.06 & 0.04 & 0.07 & 0.10 & 0.05 & 0.06 & 0.12 & 0.07 & 0.04 & 0.05 & 0.03 \\
\hline $\mathrm{K}_{2} \mathrm{O}$ & 0.01 & 0.02 & 0.04 & 0.05 & 0.02 & 0.00 & 0.02 & 0.00 & 0.01 & 0.00 & 0.01 & 0.02 & 0.01 & 0.02 & 0.05 & 0.05 & 0.01 & 0.02 & 0.04 & 0.01 & 0.01 & 0.02 & 0.02 \\
\hline total & 87.94 & 86.85 & 86.63 & 87.56 & 86.15 & 88.12 & 88.07 & 87.68 & 86.79 & 88.65 & 87.30 & 88.41 & 86.06 & 87.09 & 87.00 & 86.15 & 87.16 & 86.99 & 86.35 & 87.60 & 86.72 & 87.89 & 86.74 \\
\hline $\mathrm{K}_{2} \mathrm{O}+\mathrm{Na}_{2} \mathrm{O}+\mathrm{CaO}$ & 0.10 & 0.28 & 0.32 & 0.36 & 0.43 & 0.23 & 0.14 & 0.12 & 0.08 & 0.14 & 0.12 & 0.15 & 0.14 & 0.17 & 0.22 & 0.26 & 0.15 & 0.13 & 0.43 & 0.21 & 0.23 & 0.15 & 0.16 \\
\hline \multicolumn{24}{|l|}{ Structural formula ${ }^{b}$} \\
\hline $\mathrm{Si}$ & 2.90 & 3.15 & 3.14 & 3.12 & 3.18 & 3.02 & 2.82 & 3.01 & 2.93 & 2.97 & 2.81 & 2.78 & 2.79 & 2.93 & 3.04 & 3.04 & 2.99 & 2.88 & 3.05 & 3.00 & 3.05 & 2.89 & 2.82 \\
\hline $\mathrm{Ti}$ & 0.00 & 0.00 & 0.01 & 0.00 & 0.00 & 0.00 & 0.01 & 0.00 & 0.00 & 0.00 & 0.00 & 0.00 & 0.00 & 0.00 & 0.00 & 0.00 & 0.01 & 0.01 & 0.00 & 0.00 & 0.00 & 0.00 & 0.00 \\
\hline Al & 2.34 & 2.40 & 2.21 & 2.48 & 2.25 & 2.09 & 2.37 & 2.11 & 2.29 & 2.20 & 2.48 & 2.45 & 2.45 & 2.21 & 2.22 & 2.22 & 2.19 & 2.42 & 2.19 & 2.21 & 2.15 & 2.48 & 2.55 \\
\hline$A I^{\prime V}$ & 1.10 & 0.85 & 0.86 & 0.88 & 0.82 & 0.98 & 1.18 & 0.99 & 1.07 & 1.03 & 1.19 & 1.22 & 1.21 & 1.07 & 0.96 & 0.96 & 1.01 & 1.12 & 0.95 & 1.00 & 0.95 & 1.11 & 1.18 \\
\hline$A l^{\mathrm{VI}}$ & 1.24 & 1.55 & 1.35 & 1.60 & 1.43 & 1.11 & 1.19 & 1.12 & 1.22 & 1.17 & 1.29 & 1.23 & 1.24 & 1.14 & 1.26 & 1.27 & 1.18 & 1.30 & 1.24 & 1.21 & 1.21 & 1.37 & 1.37 \\
\hline $\mathrm{Cr}$ & 0.00 & 0.01 & 0.00 & 0.00 & 0.00 & 0.00 & 0.01 & 0.00 & 0.01 & 0.02 & 0.01 & 0.00 & 0.00 & 0.01 & 0.02 & 0.03 & 0.04 & 0.00 & 0.03 & 0.04 & 0.02 & 0.01 & 0.00 \\
\hline $\mathrm{Fe}$ & 1.99 & 1.64 & 1.68 & 1.69 & 1.80 & 1.92 & 2.12 & 1.86 & 1.98 & 2.08 & 2.22 & 2.24 & 2.67 & 1.92 & 1.83 & 1.84 & 1.95 & 2.17 & 1.96 & 1.98 & 1.99 & 2.09 & 2.23 \\
\hline$M n$ & 0.02 & 0.03 & 0.03 & 0.05 & 0.03 & 0.03 & 0.03 & 0.02 & 0.02 & 0.04 & 0.02 & 0.03 & 0.02 & 0.05 & 0.05 & 0.05 & 0.03 & 0.04 & 0.03 & 0.03 & 0.02 & 0.02 & 0.03 \\
\hline $\mathrm{Mg}$ & 2.65 & 2.38 & 2.65 & 2.25 & 2.37 & 2.84 & 2.62 & 2.91 & 2.67 & 2.59 & 2.39 & 2.47 & 2.03 & 2.83 & 2.66 & 2.59 & 2.66 & 2.37 & 2.53 & 2.59 & 2.59 & 2.36 & 2.26 \\
\hline $\mathrm{Ni}$ & 0.01 & 0.01 & 0.01 & 0.01 & 0.01 & 0.01 & 0.00 & 0.01 & 0.01 & 0.01 & 0.00 & 0.00 & 0.00 & 0.01 & 0.00 & 0.01 & 0.01 & 0.00 & 0.01 & 0.01 & 0.00 & 0.00 & 0.00 \\
\hline $\mathrm{Ca}$ & 0.01 & 0.02 & 0.02 & 0.03 & 0.03 & 0.02 & 0.01 & 0.01 & 0.01 & 0.01 & 0.01 & 0.01 & 0.01 & 0.01 & 0.01 & 0.01 & 0.01 & 0.01 & 0.03 & 0.01 & 0.02 & 0.01 & 0.01 \\
\hline $\mathrm{Na}$ & 0.00 & 0.02 & 0.01 & 0.01 & 0.02 & 0.00 & 0.01 & 0.01 & 0.00 & 0.01 & 0.01 & 0.01 & 0.01 & 0.01 & 0.01 & 0.02 & 0.01 & 0.01 & 0.02 & 0.01 & 0.01 & 0.01 & 0.01 \\
\hline K & 0.00 & 0.00 & 0.00 & 0.01 & 0.00 & 0.00 & 0.00 & 0.00 & 0.00 & 0.00 & 0.00 & 0.00 & 0.00 & 0.00 & 0.01 & 0.01 & 0.00 & 0.00 & 0.01 & 0.00 & 0.00 & 0.00 & 0.00 \\
\hline octaedral sum & 5.92 & 5.65 & 5.75 & 5.64 & 5.70 & 5.93 & 5.99 & 5.94 & 5.92 & 5.92 & 5.94 & 5.99 & 5.99 & 5.97 & 5.85 & 5.84 & 5.89 & 5.91 & 5.86 & 5.89 & 5.86 & 5.86 & 5.91 \\
\hline vacancies & 0.08 & 0.35 & 0.25 & 0.36 & 0.30 & 0.07 & 0.01 & 0.06 & 0.08 & 0.08 & 0.06 & 0.01 & 0.01 & 0.03 & 0.15 & 0.16 & 0.11 & 0.09 & 0.14 & 0.11 & 0.14 & 0.14 & 0.09 \\
\hline $\mathrm{Mg} \#^{\mathrm{c}}$ & 0.57 & 0.59 & 0.61 & 0.57 & 0.57 & 0.60 & 0.55 & 0.61 & 0.57 & 0.56 & 0.52 & 0.52 & 0.43 & 0.60 & 0.59 & 0.58 & 0.58 & 0.52 & 0.56 & 0.57 & 0.57 & 0.53 & 0.50 \\
\hline $\mathbf{R}^{2+d}$ & 4.67 & 4.06 & 4.37 & 4.00 & 4.21 & 4.80 & 4.77 & 4.80 & 4.68 & 4.71 & 4.63 & 4.73 & 4.72 & 4.80 & 4.54 & 4.50 & 4.65 & 4.58 & 4.53 & 4.62 & 4.60 & 4.46 & 4.52 \\
\hline \multicolumn{24}{|l|}{ Calculated T $\left({ }^{\circ} \mathrm{C}\right)$} \\
\hline Bourdelle et al. (2013) ${ }^{e}$ & 284 & 113 & 138 & 116 & 120 & 274 & 1305 & 278 & 276 & 272 & 359 & 863 & 612 & 399 & 192 & 185 & 243 & 262 & 193 & 231 & 200 & 223 & 273 \\
\hline Tcorrected $\left(>350^{\circ} \mathrm{C}\right)^{e}$ & & & & & & & 492 & & & & 317 & 444 & 398 & 334 & & & & & & & & & \\
\hline
\end{tabular}

1618 


\begin{tabular}{|c|c|c|c|c|c|c|c|c|c|c|c|c|c|c|c|c|c|c|c|c|c|c|c|}
\hline Sample & $218 a$ & $218 a$ & $218 a$ & $218 a$ & $218 a$ & $218 a$ & $218 a$ & $218 a$ & $218 a$ & $218 a$ & $218 a$ & $218 a$ & $218 a$ & $218 a$ & $218 a$ & $218 a$ & $218 a$ & $218 a$ & $218 a$ & $218 a$ & $218 a$ & $218 a$ & $218 a$ \\
\hline Clast vs matrix & Clast & Clast & Clast & Clast & Clast & Clast & Clast & Clast & Clast & Clast & Clast & Clast & Clast & Clast & Clast & Clast & Clast & Clast & Clast & Clast & Clast & Clast & Clast \\
\hline Analysis \# & 22 & 29 & 30 & $13 / 1$ & $14 / 1$ & $18 / 1$ & $19 / 1$ & $20 / 1$ & $21 / 1$ & $23 / 1$ & $26 / 1$ & $27 / 1$ & $33 / 1$ & $39 / 1$ & $41 / 1$ & $43 / 1$ & $49 / 1$ & $56 / 1$ & $57 / 1$ & $58 / 1$ & $59 / 1$ & $60 / 1$ & $61 / 1$ \\
\hline Zone analysed & $\mathrm{C} 2$ & $\mathrm{C} 6$ & $\mathrm{C} 6$ & $\mathrm{C}-3$ & $\mathrm{C}-3$ & $C-3$ & C-3 & C-3 & C-3 & $\mathrm{C}-3$ & C-4 & $\mathrm{C}-4$ & C-4 & C-4 & C-4 & C-4 & C-5 & C-6 & C-6 & C-6 & C-7 & C-7 & C-7 \\
\hline \multicolumn{24}{|l|}{ Chlorite composition a } \\
\hline $\mathrm{SiO}_{2}$ & 27.59 & 30.42 & 27.21 & 29.33 & 28.53 & 27.11 & 27.18 & 28.94 & 25.64 & 26.69 & 29.01 & 28.37 & 29.10 & 28.70 & 27.66 & 28.07 & 28.88 & 29.91 & 30.98 & 29.13 & 28.05 & 27.65 & 28.23 \\
\hline $\mathrm{TiO}_{2}$ & 0.03 & 0.02 & 0.03 & 0.00 & 0.08 & 0.06 & 0.11 & 0.06 & 0.04 & 0.06 & 0.00 & 0.08 & 0.00 & 0.34 & 0.04 & 0.11 & 0.03 & 0.03 & 0.04 & 0.01 & 0.07 & 0.06 & 0.09 \\
\hline $\mathrm{Al}_{2} \mathrm{O}_{3}$ & 19.06 & 19.76 & 19.12 & 17.56 & 17.23 & 19.43 & 18.92 & 18.86 & 19.64 & 19.08 & 19.64 & 19.59 & 17.66 & 18.09 & 18.48 & 18.21 & 17.55 & 17.48 & 15.91 & 18.13 & 19.30 & 19.37 & 19.31 \\
\hline $\mathrm{Cr}_{2} \mathrm{O}_{3}$ & 0.03 & 0.04 & 0.05 & 0.07 & 0.07 & 0.08 & 0.19 & 0.00 & 0.04 & 0.12 & 0.04 & 0.08 & 0.17 & 0.05 & 0.17 & 0.12 & 0.16 & 0.66 & 0.64 & 0.35 & 0.09 & 0.05 & 0.01 \\
\hline $\mathrm{FeO}$ & 23.76 & 9.81 & 24.59 & 23.27 & 23.60 & 25.89 & 23.53 & 18.33 & 28.21 & 26.53 & 18.58 & 17.75 & 22.42 & 20.09 & 21.23 & 21.92 & 18.37 & 17.41 & 14.20 & 14.87 & 18.70 & 19.11 & 18.76 \\
\hline $\mathrm{MnO}$ & 0.42 & 0.25 & 0.47 & 0.58 & 0.45 & 0.51 & 0.59 & 0.73 & 0.37 & 0.50 & 0.21 & 0.18 & 0.44 & 0.57 & 0.35 & 0.54 & 0.30 & 0.01 & 0.06 & 0.11 & 0.23 & 0.07 & 0.20 \\
\hline MgO & 17.14 & 27.78 & 16.45 & 16.29 & 16.29 & 13.86 & 15.44 & 21.24 & 12.65 & 13.98 & 20.59 & 21.11 & 17.87 & 17.73 & 18.06 & 16.77 & 21.61 & 21.13 & 25.20 & 23.31 & 19.73 & 20.50 & 20.66 \\
\hline $\mathrm{NiO}$ & 0.01 & 0.10 & 0.00 & 0.00 & 0.11 & 0.00 & 0.02 & 0.04 & 0.09 & 0.00 & 0.00 & 0.08 & 0.05 & 0.06 & 0.06 & 0.11 & 0.08 & 0.23 & 0.26 & 0.23 & 0.02 & 0.05 & 0.00 \\
\hline $\mathrm{CaO}$ & 0.13 & 0.03 & 0.09 & 0.23 & 0.24 & 0.15 & 0.26 & 0.07 & 0.05 & 0.11 & 0.04 & 0.11 & 0.17 & 0.46 & 0.15 & 0.23 & 0.09 & 0.07 & 0.01 & 0.02 & 0.19 & 0.03 & 0.03 \\
\hline $\mathrm{Na}_{2} \mathrm{O}$ & 0.04 & 0.02 & 0.03 & 0.00 & 0.02 & 0.04 & 0.01 & 0.00 & 0.05 & 0.02 & 0.01 & 0.00 & 0.02 & 0.01 & 0.03 & 0.00 & 0.03 & 0.00 & 0.00 & 0.00 & 0.06 & 0.03 & 0.01 \\
\hline $\mathrm{K}_{2} \mathrm{O}$ & 0.01 & 0.02 & 0.01 & 0.03 & 0.02 & 0.01 & 0.01 & 0.02 & 0.03 & 0.00 & 0.00 & 0.00 & 0.01 & 0.01 & 0.00 & 0.04 & 0.01 & 0.00 & 0.00 & 0.04 & 0.05 & 0.02 & 0.01 \\
\hline total & 88.23 & 88.23 & 88.06 & 87.37 & 86.64 & 87.14 & 86.26 & 88.29 & 86.82 & 87.10 & 88.10 & 87.34 & 87.92 & 86.10 & 86.24 & 86.13 & 87.11 & 86.94 & 87.33 & 86.21 & 86.48 & 86.93 & 87.31 \\
\hline $\mathrm{K}_{2} \mathrm{O}+\mathrm{Na}_{2} \mathrm{O}+\mathrm{CaO}$ & 0.18 & 0.07 & 0.14 & 0.26 & 0.28 & 0.20 & 0.28 & 0.09 & 0.13 & 0.13 & 0.05 & 0.11 & 0.20 & 0.48 & 0.18 & 0.27 & 0.13 & 0.08 & 0.02 & 0.06 & 0.29 & 0.08 & 0.05 \\
\hline \multicolumn{24}{|l|}{ Structural formula ${ }^{b}$} \\
\hline $\mathrm{Si}$ & 2.86 & 2.92 & 2.84 & 3.06 & 3.01 & 2.88 & 2.89 & 2.91 & 2.78 & 2.85 & 2.92 & 2.87 & 3.00 & 2.99 & 2.90 & 2.96 & 2.95 & 3.04 & 3.08 & 2.95 & 2.89 & 2.84 & 2.88 \\
\hline $\mathrm{Ti}$ & 0.00 & 0.00 & 0.00 & 0.00 & 0.01 & 0.01 & 0.01 & 0.00 & 0.00 & 0.00 & 0.00 & 0.01 & 0.00 & 0.03 & 0.00 & 0.01 & 0.00 & 0.00 & 0.00 & 0.00 & 0.01 & 0.00 & 0.01 \\
\hline Al & 2.33 & 2.24 & 2.36 & 2.16 & 2.15 & 2.43 & 2.37 & 2.24 & 2.51 & 2.40 & 2.33 & 2.34 & 2.15 & 2.22 & 2.28 & 2.26 & 2.11 & 2.09 & 1.87 & 2.16 & 2.34 & 2.34 & 2.32 \\
\hline Alv & 1.14 & 1.08 & 1.16 & 0.94 & 0.99 & 1.12 & 1.11 & 1.09 & 1.22 & 1.15 & 1.08 & 1.13 & 1.00 & 1.01 & 1.10 & 1.04 & 1.05 & 0.96 & 0.92 & 1.05 & 1.11 & 1.16 & 1.12 \\
\hline $\mathrm{Al}^{\mathrm{VI}}$ & 1.19 & 1.16 & 1.20 & 1.21 & 1.16 & 1.32 & 1.26 & 1.15 & 1.29 & 1.26 & 1.24 & 1.21 & 1.15 & 1.22 & 1.19 & 1.22 & 1.06 & 1.13 & 0.95 & 1.11 & 1.23 & 1.18 & 1.19 \\
\hline $\mathrm{Cr}$ & 0.00 & 0.00 & 0.00 & 0.01 & 0.01 & 0.01 & 0.02 & 0.00 & 0.00 & 0.01 & 0.00 & 0.01 & 0.01 & 0.00 & 0.01 & 0.01 & 0.01 & 0.05 & 0.05 & 0.03 & 0.01 & 0.00 & 0.00 \\
\hline $\mathrm{Fe}$ & 2.06 & 0.79 & 2.15 & 2.03 & 2.09 & 2.30 & 2.09 & 1.54 & 2.56 & 2.37 & 1.56 & 1.50 & 1.94 & 1.75 & 1.86 & 1.93 & 1.57 & 1.48 & 1.18 & 1.26 & 1.61 & 1.64 & 1.60 \\
\hline$M n$ & 0.04 & 0.02 & 0.04 & 0.05 & 0.04 & 0.05 & 0.05 & 0.06 & 0.03 & 0.04 & 0.02 & 0.02 & 0.04 & 0.05 & 0.03 & 0.05 & 0.03 & 0.00 & 0.01 & 0.01 & 0.02 & 0.01 & 0.02 \\
\hline $\mathrm{Mg}$ & 2.65 & 3.98 & 2.56 & 2.53 & 2.57 & 2.20 & 2.45 & 3.19 & 2.05 & 2.23 & 3.09 & 3.19 & 2.75 & 2.76 & 2.82 & 2.64 & 3.29 & 3.20 & 3.74 & 3.52 & 3.03 & 3.14 & 3.14 \\
\hline $\mathrm{Ni}$ & 0.00 & 0.01 & 0.00 & 0.00 & 0.01 & 0.00 & 0.00 & 0.00 & 0.01 & 0.00 & 0.00 & 0.01 & 0.00 & 0.01 & 0.01 & 0.01 & 0.01 & 0.02 & 0.02 & 0.02 & 0.00 & 0.00 & 0.00 \\
\hline $\mathrm{Ca}$ & 0.01 & 0.00 & 0.01 & 0.03 & 0.03 & 0.02 & 0.03 & 0.01 & 0.01 & 0.01 & 0.00 & 0.01 & 0.02 & 0.05 & 0.02 & 0.03 & 0.01 & 0.01 & 0.00 & 0.00 & 0.02 & 0.00 & 0.00 \\
\hline $\mathrm{Na}$ & 0.01 & 0.00 & 0.01 & 0.00 & 0.00 & 0.01 & 0.00 & 0.00 & 0.01 & 0.00 & 0.00 & 0.00 & 0.00 & 0.00 & 0.01 & 0.00 & 0.01 & 0.00 & 0.00 & 0.00 & 0.01 & 0.01 & 0.00 \\
\hline K & 0.00 & 0.00 & 0.00 & 0.00 & 0.00 & 0.00 & 0.00 & 0.00 & 0.00 & 0.00 & 0.00 & 0.00 & 0.00 & 0.00 & 0.00 & 0.01 & 0.00 & 0.00 & 0.00 & 0.01 & 0.01 & 0.00 & 0.00 \\
\hline octaedral sum & 5.97 & 5.96 & 5.98 & 5.86 & 5.90 & 5.89 & 5.90 & 5.96 & 5.96 & 5.93 & 5.92 & 5.94 & 5.92 & 5.84 & 5.95 & 5.89 & 5.99 & 5.89 & 5.95 & 5.96 & 5.94 & 5.98 & 5.95 \\
\hline vacancies & 0.03 & 0.04 & 0.02 & 0.14 & 0.10 & 0.11 & 0.10 & 0.04 & 0.04 & 0.07 & 0.08 & 0.06 & 0.08 & 0.16 & 0.05 & 0.11 & 0.01 & 0.11 & 0.05 & 0.04 & 0.06 & 0.02 & 0.05 \\
\hline $\mathrm{Mg \#}{ }^{\mathrm{c}}$ & 0.56 & 0.83 & 0.54 & 0.56 & 0.55 & 0.49 & 0.54 & 0.67 & 0.44 & 0.48 & 0.66 & 0.68 & 0.59 & 0.61 & 0.60 & 0.58 & 0.68 & 0.68 & 0.76 & 0.74 & 0.65 & 0.66 & 0.66 \\
\hline$R^{2+d}$ & 4.75 & 4.79 & 4.75 & 4.61 & 4.70 & 4.54 & 4.59 & 4.80 & 4.65 & 4.65 & 4.67 & 4.71 & 4.73 & 4.57 & 4.72 & 4.63 & 4.89 & 4.70 & 4.95 & 4.81 & 4.66 & 4.79 & 4.75 \\
\hline \multicolumn{24}{|l|}{ Calculated T $\left({ }^{\circ} \mathrm{C}\right)$} \\
\hline Bourdelle et al. (2013) ${ }^{e}$ & 445 & 362 & 500 & 194 & 234 & 247 & 263 & 388 & 407 & 313 & 271 & 336 & 251 & 203 & 330 & 233 & 585 & 211 & 302 & 330 & 304 & 630 & 379 \\
\hline Tcorrected $\left(>350^{\circ} \mathrm{C}\right)^{e}$ & 351 & 319 & 369 & & & & & 330 & 337 & & & & & & & & 391 & & & & & 402 & 326 \\
\hline
\end{tabular}




\begin{tabular}{|c|c|c|c|c|c|c|c|c|c|c|c|c|c|}
\hline $\begin{array}{c}\text { Sample } \\
\text { Clast vs matrix } \\
\text { Analysis \# }\end{array}$ & $\begin{array}{l}218 a \\
\text { Clast } \\
62 / 1\end{array}$ & $\begin{array}{l}218 a \\
\text { Clast } \\
63 / 1\end{array}$ & $\begin{array}{l}218 a \\
\text { Clast } \\
64 / 1\end{array}$ & $\begin{array}{l}218 a \\
\text { Clast } \\
65 / 1\end{array}$ & $\begin{array}{c}218 a \\
\text { Mat } \\
9 / 1\end{array}$ & $\begin{array}{c}218 a \\
\text { Mat } \\
10 / 1\end{array}$ & $\begin{array}{c}218 a \\
\text { Mat } \\
11 / 1\end{array}$ & $\begin{array}{c}218 a \\
\text { Mat } \\
44 / 1\end{array}$ & $\begin{array}{c}218 a \\
\text { Mat } \\
45 / 1\end{array}$ & $\begin{array}{c}218 a \\
\text { Mat } \\
46 / 1\end{array}$ & $\begin{array}{c}218 a \\
\text { Mat } \\
47 / 1\end{array}$ & $\begin{array}{c}218 a \\
\text { Mat } \\
50 / 1\end{array}$ & $\begin{array}{c}218 a \\
\text { Mat } \\
69 / 1\end{array}$ \\
\hline \multicolumn{14}{|l|}{ Chlorite composition a } \\
\hline $\mathrm{SiO}_{2}$ & 28.23 & 29.35 & 27.75 & 28.58 & 28.20 & 30.04 & 28.31 & 27.60 & 28.93 & 28.98 & 28.65 & 30.16 & 29.44 \\
\hline $\mathrm{TiO}_{2}$ & 0.01 & 0.08 & 0.04 & 0.04 & 0.00 & 0.03 & 0.00 & 0.04 & 0.00 & 0.09 & 0.03 & 0.00 & 0.03 \\
\hline $\mathrm{Al}_{2} \mathrm{O}_{3}$ & 19.86 & 18.85 & 20.29 & 20.27 & 18.42 & 17.92 & 17.90 & 18.64 & 18.47 & 19.06 & 19.56 & 18.66 & 18.49 \\
\hline $\mathrm{Cr}_{2} \mathrm{O}_{3}$ & 0.00 & 0.01 & 0.02 & 0.11 & 0.27 & 0.67 & 0.08 & 0.11 & 0.03 & 0.04 & 0.26 & 0.17 & 0.03 \\
\hline $\mathrm{FeO}$ & 17.36 & 17.43 & 18.52 & 18.22 & 22.93 & 22.55 & 21.15 & 23.60 & 19.10 & 14.22 & 18.97 & 17.54 & 14.29 \\
\hline MnO & 0.16 & 0.17 & 0.15 & 0.21 & 0.38 & 0.40 & 0.36 & 0.43 & 0.25 & 0.28 & 0.26 & 0.26 & 0.11 \\
\hline MgO & 21.71 & 21.00 & 20.83 & 19.95 & 18.08 & 15.79 & 18.24 & 16.47 & 20.11 & 23.98 & 19.42 & 20.42 & 23.76 \\
\hline $\mathrm{NiO}$ & 0.02 & 0.07 & 0.16 & 0.06 & 0.10 & 0.04 & 0.16 & 0.04 & 0.25 & 0.10 & 0.11 & 0.02 & 0.28 \\
\hline $\mathrm{CaO}$ & 0.00 & 0.11 & 0.03 & 0.06 & 0.05 & 0.28 & 0.10 & 0.15 & 0.00 & 0.07 & 0.11 & 0.06 & 0.06 \\
\hline $\mathrm{Na}_{2} \mathrm{O}$ & 0.00 & 0.01 & 0.01 & 0.00 & 0.00 & 0.05 & 0.08 & 0.03 & 0.00 & 0.02 & 0.08 & 0.05 & 0.00 \\
\hline $\mathrm{K}_{2} \mathrm{O}$ & 0.00 & 0.00 & 0.02 & 0.02 & 0.00 & 0.08 & 0.00 & 0.00 & 0.00 & 0.03 & 0.03 & 0.03 & 0.01 \\
\hline total & 87.35 & 87.08 & 87.82 & 87.52 & 88.42 & 87.85 & 86.38 & 87.11 & 87.13 & 86.87 & 87.50 & 87.37 & 86.49 \\
\hline $\mathrm{K}_{2} \mathrm{O}+\mathrm{Na}_{2} \mathrm{O}+\mathrm{CaO}$ & 0.00 & 0.11 & 0.05 & 0.09 & 0.05 & 0.40 & 0.18 & 0.18 & 0.00 & 0.12 & 0.23 & 0.13 & 0.07 \\
\hline \multicolumn{14}{|l|}{ Structural formula ${ }^{b}$} \\
\hline $\mathrm{Si}$ & 2.85 & 2.97 & 2.81 & 2.89 & 2.91 & 3.10 & 2.96 & 2.90 & 2.96 & 2.90 & 2.92 & 3.04 & 2.96 \\
\hline $\mathrm{Ti}$ & 0.00 & 0.01 & 0.00 & 0.00 & 0.00 & 0.00 & 0.00 & 0.00 & 0.00 & 0.01 & 0.00 & 0.00 & 0.00 \\
\hline Al & 2.36 & 2.25 & 2.42 & 2.42 & 2.24 & 2.18 & 2.21 & 2.31 & 2.23 & 2.25 & 2.35 & 2.22 & 2.19 \\
\hline $\mathrm{All}^{\mathrm{IV}}$ & 1.15 & 1.03 & 1.19 & 1.11 & 1.09 & 0.90 & 1.04 & 1.10 & 1.04 & 1.10 & 1.08 & 0.96 & 1.04 \\
\hline $\mathrm{Al}^{\mathrm{VI}}$ & 1.21 & 1.22 & 1.23 & 1.31 & 1.14 & 1.28 & 1.17 & 1.21 & 1.18 & 1.15 & 1.26 & 1.25 & 1.14 \\
\hline $\mathrm{Cr}$ & 0.00 & 0.00 & 0.00 & 0.01 & 0.02 & 0.05 & 0.01 & 0.01 & 0.00 & 0.00 & 0.02 & 0.01 & 0.00 \\
\hline $\mathrm{Fe}$ & 1.47 & 1.48 & 1.57 & 1.54 & 1.98 & 1.94 & 1.85 & 2.07 & 1.63 & 1.19 & 1.61 & 1.48 & 1.20 \\
\hline $\mathrm{Mn}$ & 0.01 & 0.01 & 0.01 & 0.02 & 0.03 & 0.03 & 0.03 & 0.04 & 0.02 & 0.02 & 0.02 & 0.02 & 0.01 \\
\hline Mg & 3.27 & 3.17 & 3.14 & 3.01 & 2.78 & 2.43 & 2.84 & 2.58 & 3.07 & 3.58 & 2.95 & 3.07 & 3.56 \\
\hline $\mathrm{Ni}$ & 0.00 & 0.01 & 0.01 & 0.00 & 0.01 & 0.00 & 0.01 & 0.00 & 0.02 & 0.01 & 0.01 & 0.00 & 0.02 \\
\hline $\mathrm{Ca}$ & 0.00 & 0.01 & 0.00 & 0.01 & 0.01 & 0.03 & 0.01 & 0.02 & 0.00 & 0.01 & 0.01 & 0.01 & 0.01 \\
\hline $\mathrm{Na}$ & 0.00 & 0.00 & 0.00 & 0.00 & 0.00 & 0.01 & 0.02 & 0.01 & 0.00 & 0.00 & 0.02 & 0.01 & 0.00 \\
\hline $\mathrm{K}$ & 0.00 & 0.00 & 0.00 & 0.00 & 0.00 & 0.01 & 0.00 & 0.00 & 0.00 & 0.00 & 0.00 & 0.00 & 0.00 \\
\hline octaedral sum & 5.97 & 5.90 & 5.98 & 5.89 & 5.96 & 5.79 & 5.94 & 5.94 & 5.93 & 5.97 & 5.91 & 5.85 & 5.94 \\
\hline vacancies & 0.03 & 0.10 & 0.02 & 0.11 & 0.04 & 0.21 & 0.06 & 0.06 & 0.07 & 0.03 & 0.09 & 0.15 & 0.06 \\
\hline$M g \#{ }^{c}$ & 0.69 & 0.68 & 0.67 & 0.66 & 0.58 & 0.56 & 0.61 & 0.55 & 0.65 & 0.75 & 0.65 & 0.67 & 0.75 \\
\hline$R^{2+d}$ & 4.75 & 4.66 & 4.74 & 4.57 & 4.79 & 4.41 & 4.74 & 4.70 & 4.74 & 4.80 & 4.59 & 4.57 & 4.79 \\
\hline \multicolumn{14}{|l|}{ Calculated $\mathrm{T}\left({ }^{\circ} \mathrm{C}\right)$} \\
\hline Bourdelle et al. (2013) ${ }^{e}$ & 422 & 236 & 494 & 245 & 393 & 152 & 284 & 309 & 267 & 415 & 246 & 188 & 300 \\
\hline Tcorrected $\left(>350^{\circ} \mathrm{C}\right)^{e}$ & 343 & & 367 & & 332 & & & & & 340 & & & \\
\hline
\end{tabular}

1622 


\begin{tabular}{|c|c|c|c|c|c|c|c|c|c|c|c|c|c|c|c|c|c|c|c|c|c|c|}
\hline Sample & $218 c$ & $218 c$ & $218 c$ & $218 c$ & $218 c$ & $218 \mathrm{c}$ & $218 c$ & $218 c$ & $218 c$ & $218 c$ & $218 c$ & $218 c$ & $218 \mathrm{c}$ & $218 c$ & $218 c$ & $218 c$ & $218 c$ & $218 c$ & $218 c$ & $218 c$ & $218 c$ & $218 c$ \\
\hline Clast vs matrix & Clast & Clast & Clast & Clast & Clast & Clast & Clast & Clast & Clast & Clast & Clast & Clast & Clast & Clast & Clast & Clast & Clast & Clast & Clast & Clast & Clast & Clast \\
\hline Analysis \# & $33 / 1$ & $38 / 1$ & $39 / 1$ & $40 / 1$ & $41 / 1$ & $42 / 1$ & $101 /$ & $102 /$ & $103 /$ & $103 /$ & $103 /$ & $103 /$ & $103 /$ & $103 /$ & $103 /$ & $103 /$ & $103 /$ & $103 /$ & $103 /$ & $103 /$ & $103 /$ & $104 /$ \\
\hline \multicolumn{23}{|l|}{ Chlorite composition a } \\
\hline $\mathrm{SiO}_{2}$ & 28.75 & 28.61 & 28.38 & 28.00 & 28.29 & 28.44 & 27.80 & 28.02 & 27.66 & 27.81 & 28.39 & 28.56 & 27.99 & 28.37 & 28.54 & 28.60 & 28.45 & 27.75 & 28.02 & 28.96 & 28.54 & 30.11 \\
\hline $\mathrm{TiO}_{2}$ & 0.14 & 0.02 & 0.03 & 0.67 & 0.05 & 0.08 & 0.04 & 0.04 & 0.03 & 0.00 & 0.06 & 0.03 & 0.07 & 0.10 & 0.06 & 0.14 & 0.06 & 0.09 & 0.17 & 0.39 & 0.08 & 0.02 \\
\hline $\mathrm{Al}_{2} \mathrm{O}_{3}$ & 18.97 & 18.75 & 19.48 & 19.58 & 19.71 & 19.08 & 19.25 & 18.25 & 19.14 & 19.10 & 19.93 & 18.93 & 19.01 & 19.32 & 19.88 & 19.38 & 19.07 & 19.85 & 19.33 & 19.66 & 19.59 & 18.50 \\
\hline $\mathrm{Cr}_{2} \mathrm{O}_{3}$ & 0.41 & 0.01 & 0.00 & 0.02 & 0.03 & 0.03 & 0.33 & 0.19 & 0.29 & 0.18 & 0.11 & 0.13 & 0.00 & 0.08 & 0.00 & 0.04 & 0.04 & 0.17 & 0.00 & 0.10 & 0.09 & 0.12 \\
\hline $\mathrm{FeO}$ & 19.01 & 18.52 & 17.89 & 16.44 & 17.60 & 19.25 & 20.10 & 20.73 & 19.67 & 18.92 & 18.31 & 19.41 & 19.11 & 19.49 & 19.89 & 19.64 & 20.55 & 18.36 & 19.79 & 19.49 & 20.95 & 13.56 \\
\hline MnO & 0.22 & 0.26 & 0.27 & 0.17 & 0.26 & 0.21 & 0.27 & 0.31 & 0.28 & 0.31 & 0.28 & 0.22 & 0.22 & 0.30 & 0.35 & 0.27 & 0.18 & 0.17 & 0.21 & 0.26 & 0.34 & 0.28 \\
\hline MgO & 20.59 & 20.17 & 21.41 & 22.15 & 21.14 & 19.97 & 19.22 & 19.21 & 18.95 & 19.65 & 19.58 & 19.23 & 19.61 & 18.82 & 19.43 & 19.90 & 18.89 & 20.27 & 18.44 & 19.42 & 18.63 & 24.56 \\
\hline $\mathrm{NiO}$ & 0.17 & 0.07 & 0.12 & 0.06 & 0.08 & 0.13 & 0.09 & 0.04 & 0.11 & 0.13 & 0.05 & 0.03 & 0.09 & 0.00 & 0.00 & 0.16 & 0.09 & 0.05 & 0.05 & 0.08 & 0.07 & 0.14 \\
\hline $\mathrm{CaO}$ & 0.13 & 0.05 & 0.04 & 0.05 & 0.06 & 0.07 & 0.06 & 0.05 & 0.05 & 0.06 & 0.09 & 0.09 & 0.08 & 0.06 & 0.09 & 0.12 & 0.10 & 0.09 & 0.20 & 0.25 & 0.11 & 0.05 \\
\hline $\mathrm{Na}_{2} \mathrm{O}$ & 0.02 & 0.04 & 0.00 & 0.01 & 0.04 & 0.02 & 0.09 & 0.02 & 0.03 & 0.04 & 0.00 & 0.04 & 0.00 & 0.05 & 0.00 & 0.00 & 0.00 & 0.00 & 0.05 & 0.05 & 0.03 & 0.03 \\
\hline $\mathrm{K}_{2} \mathrm{O}$ & 0.01 & 0.00 & 0.02 & 0.01 & 0.00 & 0.02 & 0.00 & 0.00 & 0.02 & 0.01 & 0.02 & 0.00 & 0.02 & 0.05 & 0.01 & 0.02 & 0.00 & 0.00 & 0.00 & 0.01 & 0.02 & 0.00 \\
\hline total & 88.41 & 86.49 & 87.62 & 87.16 & 87.26 & 87.28 & 87.24 & 86.87 & 86.22 & 86.20 & 86.82 & 86.67 & 86.22 & 86.65 & 88.23 & 88.26 & 87.43 & 86.79 & 86.26 & 88.67 & 88.46 & 87.36 \\
\hline $\mathrm{K}_{2} \mathrm{O}+\mathrm{Na}_{2} \mathrm{O}+\mathrm{CaO}$ & 0.16 & 0.09 & 0.05 & 0.07 & 0.10 & 0.10 & 0.15 & 0.08 & 0.10 & 0.11 & 0.11 & 0.13 & 0.11 & 0.16 & 0.10 & 0.14 & 0.10 & 0.09 & 0.25 & 0.30 & 0.17 & 0.07 \\
\hline \multicolumn{23}{|l|}{ Structural formula ${ }^{b}$} \\
\hline $\mathrm{Si}$ & 2.90 & 2.94 & 2.87 & 2.83 & 2.87 & 2.91 & 2.86 & 2.91 & 2.88 & 2.88 & 2.90 & 2.94 & 2.90 & 2.92 & 2.89 & 2.90 & 2.92 & 2.84 & 2.91 & 2.91 & 2.90 & 2.98 \\
\hline $\mathrm{Ti}$ & 0.01 & 0.00 & 0.00 & 0.05 & 0.00 & 0.01 & 0.00 & 0.00 & 0.00 & 0.00 & 0.00 & 0.00 & 0.01 & 0.01 & 0.00 & 0.01 & 0.00 & 0.01 & 0.01 & 0.03 & 0.01 & 0.00 \\
\hline Al & 2.25 & 2.27 & 2.32 & 2.33 & 2.35 & 2.30 & 2.34 & 2.23 & 2.35 & 2.33 & 2.40 & 2.30 & 2.32 & 2.35 & 2.37 & 2.31 & 2.31 & 2.40 & 2.36 & 2.33 & 2.35 & 2.16 \\
\hline$A I^{I V}$ & 1.10 & 1.06 & 1.13 & 1.17 & 1.13 & 1.09 & 1.14 & 1.09 & 1.12 & 1.12 & 1.10 & 1.06 & 1.10 & 1.08 & 1.11 & 1.10 & 1.08 & 1.16 & 1.09 & 1.09 & 1.10 & 1.02 \\
\hline $\mathbf{A l}^{\mathrm{VI}}$ & 1.15 & 1.21 & 1.19 & 1.16 & 1.22 & 1.20 & 1.20 & 1.14 & 1.22 & 1.21 & 1.30 & 1.24 & 1.22 & 1.27 & 1.26 & 1.21 & 1.23 & 1.24 & 1.27 & 1.24 & 1.25 & 1.14 \\
\hline $\mathrm{Cr}$ & 0.03 & 0.00 & 0.00 & 0.00 & 0.00 & 0.00 & 0.03 & 0.02 & 0.02 & 0.01 & 0.01 & 0.01 & 0.00 & 0.01 & 0.00 & 0.00 & 0.00 & 0.01 & 0.00 & 0.01 & 0.01 & 0.01 \\
\hline $\mathrm{Fe}$ & 1.60 & 1.59 & 1.51 & 1.39 & 1.49 & 1.64 & 1.73 & 1.80 & 1.71 & 1.64 & 1.56 & 1.67 & 1.65 & 1.68 & 1.68 & 1.66 & 1.76 & 1.57 & 1.72 & 1.64 & 1.78 & 1.12 \\
\hline $\mathrm{Mn}$ & 0.02 & 0.02 & 0.02 & 0.01 & 0.02 & 0.02 & 0.02 & 0.03 & 0.02 & 0.03 & 0.02 & 0.02 & 0.02 & 0.03 & 0.03 & 0.02 & 0.02 & 0.01 & 0.02 & 0.02 & 0.03 & 0.02 \\
\hline Mg & 3.10 & 3.09 & 3.23 & 3.33 & 3.19 & 3.04 & 2.95 & 2.97 & 2.94 & 3.03 & 2.98 & 2.95 & 3.02 & 2.89 & 2.93 & 3.00 & 2.89 & 3.09 & 2.85 & 2.91 & 2.82 & 3.62 \\
\hline $\mathrm{Ni}$ & 0.01 & 0.01 & 0.01 & 0.00 & 0.01 & 0.01 & 0.01 & 0.00 & 0.01 & 0.01 & 0.00 & 0.00 & 0.01 & 0.00 & 0.00 & 0.01 & 0.01 & 0.00 & 0.00 & 0.01 & 0.01 & 0.01 \\
\hline $\mathrm{Ca}$ & 0.01 & 0.01 & 0.00 & 0.01 & 0.01 & 0.01 & 0.01 & 0.01 & 0.01 & 0.01 & 0.01 & 0.01 & 0.01 & 0.01 & 0.01 & 0.01 & 0.01 & 0.01 & 0.02 & 0.03 & 0.01 & 0.00 \\
\hline $\mathrm{Na}$ & 0.00 & 0.01 & 0.00 & 0.00 & 0.01 & 0.00 & 0.02 & 0.00 & 0.01 & 0.01 & 0.00 & 0.01 & 0.00 & 0.01 & 0.00 & 0.00 & 0.00 & 0.00 & 0.01 & 0.01 & 0.01 & 0.01 \\
\hline $\mathrm{K}$ & 0.00 & 0.00 & 0.00 & 0.00 & 0.00 & 0.00 & 0.00 & 0.00 & 0.00 & 0.00 & 0.00 & 0.00 & 0.00 & 0.01 & 0.00 & 0.00 & 0.00 & 0.00 & 0.00 & 0.00 & 0.00 & 0.00 \\
\hline octaedral sum & 5.94 & 5.93 & 5.97 & 5.91 & 5.95 & 5.93 & 5.96 & 5.97 & 5.94 & 5.95 & 5.89 & 5.91 & 5.93 & 5.89 & 5.92 & 5.93 & 5.92 & 5.94 & 5.89 & 5.87 & 5.91 & 5.94 \\
\hline vacancies & 0.06 & 0.07 & 0.03 & 0.09 & 0.05 & 0.07 & 0.04 & 0.03 & 0.06 & 0.05 & 0.11 & 0.09 & 0.07 & 0.11 & 0.08 & 0.07 & 0.08 & 0.06 & 0.11 & 0.13 & 0.09 & 0.06 \\
\hline Mg\#c & 0.66 & 0.66 & 0.68 & 0.71 & 0.68 & 0.65 & 0.63 & 0.62 & 0.63 & 0.65 & 0.66 & 0.64 & 0.65 & 0.63 & 0.64 & 0.64 & 0.62 & 0.66 & 0.62 & 0.64 & 0.61 & 0.76 \\
\hline $\mathbf{R}^{2+d}$ & 4.73 & 4.71 & 4.77 & 4.74 & 4.71 & 4.72 & 4.71 & 4.80 & 4.68 & 4.71 & 4.57 & 4.64 & 4.71 & 4.60 & 4.65 & 4.70 & 4.68 & 4.68 & 4.59 & 4.58 & 4.64 & 4.78 \\
\hline \multicolumn{23}{|l|}{ Calculated $\mathrm{T}\left({ }^{\circ} \mathrm{C}\right)$} \\
\hline Bourdelle et al. (2013) $e$ & 322 & 278 & 418 & 373 & 351 & 303 & 371 & 410 & 313 & 334 & 242 & 250 & 305 & 242 & 280 & 299 & 270 & 349 & 248 & 234 & 269 & 285 \\
\hline Tcorrected $\left(>350^{\circ} \mathrm{C}\right)^{e}$ & & & 341 & 323 & 314 & & 323 & 338 & & & & & & & & & & & & & & \\
\hline
\end{tabular}

1624

1625

1626

1627 


\begin{tabular}{|c|c|c|c|c|c|c|c|c|c|c|c|c|c|c|c|c|c|c|c|c|}
\hline Sample & 155 & 155 & 155 & 155 & 155 & 155 & 155 & 155 & 155 & 155 & 155 & 155 & 155 & 155 & 155 & 155 & 155 & 115 & 115 & 115 \\
\hline Clast vs matrix & Clast & Clast & Clast & Clast & Clast & Clast & Mat & Mat & Mat & Mat & Mat & Mat & Mat & Mat & Mat & Mat & Mat & clast & clast & clast \\
\hline Analysis \# & $83 / 1$ & $87 / 1$ & $89 / 1$ & $92 / 1$ & $93 / 1$ & $94 / 1$ & $78 / 1$ & $80 / 1$ & $89 / 1$ & $56 / 1$ & $59 / 1$ & $60 / 1$ & $61 / 1$ & $73 / 1$ & $74 / 1$ & $78 / 1$ & $79 / 1$ & $25 / 1$ & $28 / 1$ & $33 / 1$ \\
\hline \multicolumn{21}{|c|}{ Chlorite composition a } \\
\hline $\mathrm{SiO}_{2}$ & 30.66 & 28.34 & 28.78 & 26.99 & 26.58 & 27.52 & 27.14 & 27.31 & 28.80 & 29.88 & 27.78 & 26.30 & 28.12 & 26.37 & 26.72 & 26.72 & 26.64 & 28.14 & 31.06 & 30.62 \\
\hline $\mathrm{Al}_{2} \mathrm{O}_{3}$ & 19.94 & 20.83 & 19.88 & 19.73 & 20.45 & 19.92 & 20.08 & 19.97 & 18.05 & 17.19 & 19.13 & 19.38 & 19.46 & 20.03 & 20.13 & 20.48 & 20.67 & 19.12 & 16.18 & 15.94 \\
\hline $\mathrm{Cr}_{2} \mathrm{O}_{3}$ & 0.50 & 0.00 & 0.00 & 0.20 & 0.04 & 0.06 & 0.18 & 0.04 & 0.02 & 0.61 & 0.00 & 0.00 & 0.00 & 0.07 & 0.02 & 0.07 & 0.04 & 0.05 & 0.00 & 0.08 \\
\hline $\mathrm{FeO}$ & 21.27 & 17.35 & 15.81 & 23.87 & 26.12 & 22.39 & 24.36 & 22.95 & 23.72 & 21.24 & 25.96 & 27.42 & 24.31 & 28.69 & 28.29 & 24.56 & 26.33 & 17.71 & 17.14 & 16.92 \\
\hline MnO & 0.33 & 0.15 & 0.12 & 0.14 & 0.25 & 0.21 & 0.31 & 0.26 & 0.20 & 0.43 & 0.14 & 0.20 & 0.16 & 0.14 & 0.21 & 0.22 & 0.25 & 0.23 & 0.25 & 0.11 \\
\hline $\mathrm{NiO}$ & 0.06 & 0.04 & 0.03 & 0.00 & 0.00 & 0.12 & 0.02 & 0.02 & 0.00 & 0.12 & 0.07 & 0.00 & 0.04 & 0.03 & 0.05 & 0.01 & 0.08 & 0.09 & 0.10 & 0.06 \\
\hline $\mathrm{CaO}$ & 0.26 & 0.05 & 0.08 & 0.07 & 0.05 & 0.03 & 0.07 & 0.05 & 0.11 & 0.15 & 0.08 & 0.04 & 0.10 & 0.06 & 0.08 & 0.03 & 0.04 & 0.12 & 0.32 & 0.38 \\
\hline $\mathrm{Na}_{2} \mathrm{O}$ & 0.05 & 0.04 & 0.02 & 0.06 & 0.04 & 0.06 & 0.09 & 0.06 & 0.08 & 0.12 & 0.04 & 0.06 & 0.09 & 0.05 & 0.08 & 0.04 & 0.01 & 0.03 & 0.06 & 0.06 \\
\hline $\mathrm{K}_{2} \mathrm{O}$ & 0.04 & 0.02 & 0.00 & 0.01 & 0.01 & 0.00 & 0.05 & 0.04 & 0.02 & 0.03 & 0.03 & 0.04 & 0.09 & 0.02 & 0.01 & 0.01 & 0.02 & 0.03 & 0.06 & 0.05 \\
\hline total & 87.59 & 87.62 & 87.55 & 86.79 & 88.95 & 88.01 & 87.85 & 87.62 & 88.22 & 86.76 & 87.52 & 87.54 & 86.84 & 88.19 & 88.86 & 87.27 & 87.59 & 86.97 & 87.71 & 86.54 \\
\hline $\mathrm{K}_{2} \mathrm{O}+\mathrm{Na}_{2} \mathrm{O}+\mathrm{CaO}$ & 0.36 & 0.12 & 0.10 & 0.15 & 0.10 & 0.09 & 0.21 & 0.14 & 0.22 & 0.30 & 0.14 & 0.13 & 0.27 & 0.13 & 0.17 & 0.08 & 0.07 & 0.18 & 0.44 & 0.49 \\
\hline \multicolumn{21}{|l|}{ Structural formula ${ }^{b}$} \\
\hline $\mathrm{Si}$ & 3.13 & 2.85 & 2.87 & 2.85 & 2.77 & 2.84 & 2.84 & 2.84 & 2.98 & 3.11 & 2.93 & 2.81 & 2.96 & 2.81 & 2.82 & 2.81 & 2.82 & 2.87 & 3.12 & 3.12 \\
\hline $\mathrm{Ti}$ & 0.00 & 0.01 & 0.00 & 0.00 & 0.01 & 0.00 & 0.00 & 0.00 & 0.01 & 0.01 & 0.00 & 0.00 & 0.01 & 0.00 & 0.00 & 0.02 & 0.01 & 0.00 & 0.00 & 0.00 \\
\hline Al & 2.40 & 2.47 & 2.34 & 2.45 & 2.51 & 2.42 & 2.47 & 2.45 & 2.20 & 2.10 & 2.38 & 2.44 & 2.42 & 2.51 & 2.50 & 2.54 & 2.58 & 2.30 & 1.92 & 1.91 \\
\hline $\mathrm{Al}^{\mathrm{VI}}$ & 1.53 & 1.32 & 1.21 & 1.30 & 1.28 & 1.26 & 1.31 & 1.28 & 1.18 & 1.21 & 1.31 & 1.25 & 1.38 & 1.32 & 1.31 & 1.35 & 1.39 & 1.16 & 1.04 & 1.03 \\
\hline $\mathrm{Cr}$ & 0.04 & 0.00 & 0.00 & 0.02 & 0.00 & 0.01 & 0.01 & 0.00 & 0.00 & 0.05 & 0.00 & 0.00 & 0.00 & 0.01 & 0.00 & 0.01 & 0.00 & 0.00 & 0.00 & 0.01 \\
\hline $\mathrm{Fe}$ & 1.81 & 1.46 & 1.32 & 2.11 & 2.27 & 1.93 & 2.13 & 1.99 & 2.05 & 1.85 & 2.29 & 2.45 & 2.14 & 2.55 & 2.49 & 2.16 & 2.33 & 1.51 & 1.44 & 1.44 \\
\hline$M n$ & 0.03 & 0.01 & 0.01 & 0.01 & 0.02 & 0.02 & 0.03 & 0.02 & 0.02 & 0.04 & 0.01 & 0.02 & 0.01 & 0.01 & 0.02 & 0.02 & 0.02 & 0.02 & 0.02 & 0.01 \\
\hline $\mathrm{Mg}$ & 2.19 & 3.10 & 3.39 & 2.47 & 2.38 & 2.72 & 2.42 & 2.62 & 2.64 & 2.62 & 2.24 & 2.24 & 2.26 & 2.02 & 2.08 & 2.34 & 2.12 & 3.25 & 3.37 & 3.38 \\
\hline $\mathbf{N i}$ & 0.00 & 0.00 & 0.00 & 0.00 & 0.00 & 0.01 & 0.00 & 0.00 & 0.00 & 0.01 & 0.01 & 0.00 & 0.00 & 0.00 & 0.00 & 0.00 & 0.01 & 0.01 & 0.01 & 0.01 \\
\hline $\mathrm{Ca}$ & 0.03 & 0.01 & 0.01 & 0.01 & 0.01 & 0.00 & 0.01 & 0.01 & 0.01 & 0.02 & 0.01 & 0.00 & 0.01 & 0.01 & 0.01 & 0.00 & 0.00 & 0.01 & 0.03 & 0.04 \\
\hline $\mathrm{Na}$ & 0.01 & 0.01 & 0.00 & 0.01 & 0.01 & 0.01 & 0.02 & 0.01 & 0.02 & 0.02 & 0.01 & 0.01 & 0.02 & 0.01 & 0.02 & 0.01 & 0.00 & 0.01 & 0.01 & 0.01 \\
\hline K & 0.01 & 0.00 & 0.00 & 0.00 & 0.00 & 0.00 & 0.01 & 0.01 & 0.00 & 0.00 & 0.00 & 0.01 & 0.01 & 0.00 & 0.00 & 0.00 & 0.00 & 0.00 & 0.01 & 0.01 \\
\hline octaedral sum & 5.65 & 5.91 & 5.95 & 5.93 & 5.97 & 5.95 & 5.93 & 5.95 & 5.92 & 5.82 & 5.88 & 5.98 & 5.83 & 5.93 & 5.94 & 5.89 & 5.88 & 5.98 & 5.93 & 5.93 \\
\hline vacancies & 0.35 & 0.09 & 0.05 & 0.07 & 0.03 & 0.05 & 0.07 & 0.05 & 0.08 & 0.18 & 0.12 & 0.02 & 0.17 & 0.07 & 0.06 & 0.11 & 0.12 & 0.02 & 0.07 & 0.07 \\
\hline $\mathrm{Mg \#}{ }^{\mathrm{c}}$ & 0.55 & 0.68 & 0.72 & 0.54 & 0.51 & 0.58 & 0.53 & 0.57 & 0.56 & 0.59 & 0.49 & 0.48 & 0.51 & 0.44 & 0.46 & 0.52 & 0.48 & 0.68 & 0.70 & 0.70 \\
\hline$R^{2+d}$ & 4.04 & 4.58 & 4.72 & 4.59 & 4.67 & 4.68 & 4.58 & 4.64 & 4.71 & 4.51 & 4.55 & 4.71 & 4.41 & 4.59 & 4.60 & 4.52 & 4.48 & 4.79 & 4.84 & 4.84 \\
\hline ulated $\mathrm{T}\left({ }^{\circ} \mathrm{C}\right)$ & & & & & & & & & & & & & & & & & & & & \\
\hline
\end{tabular}




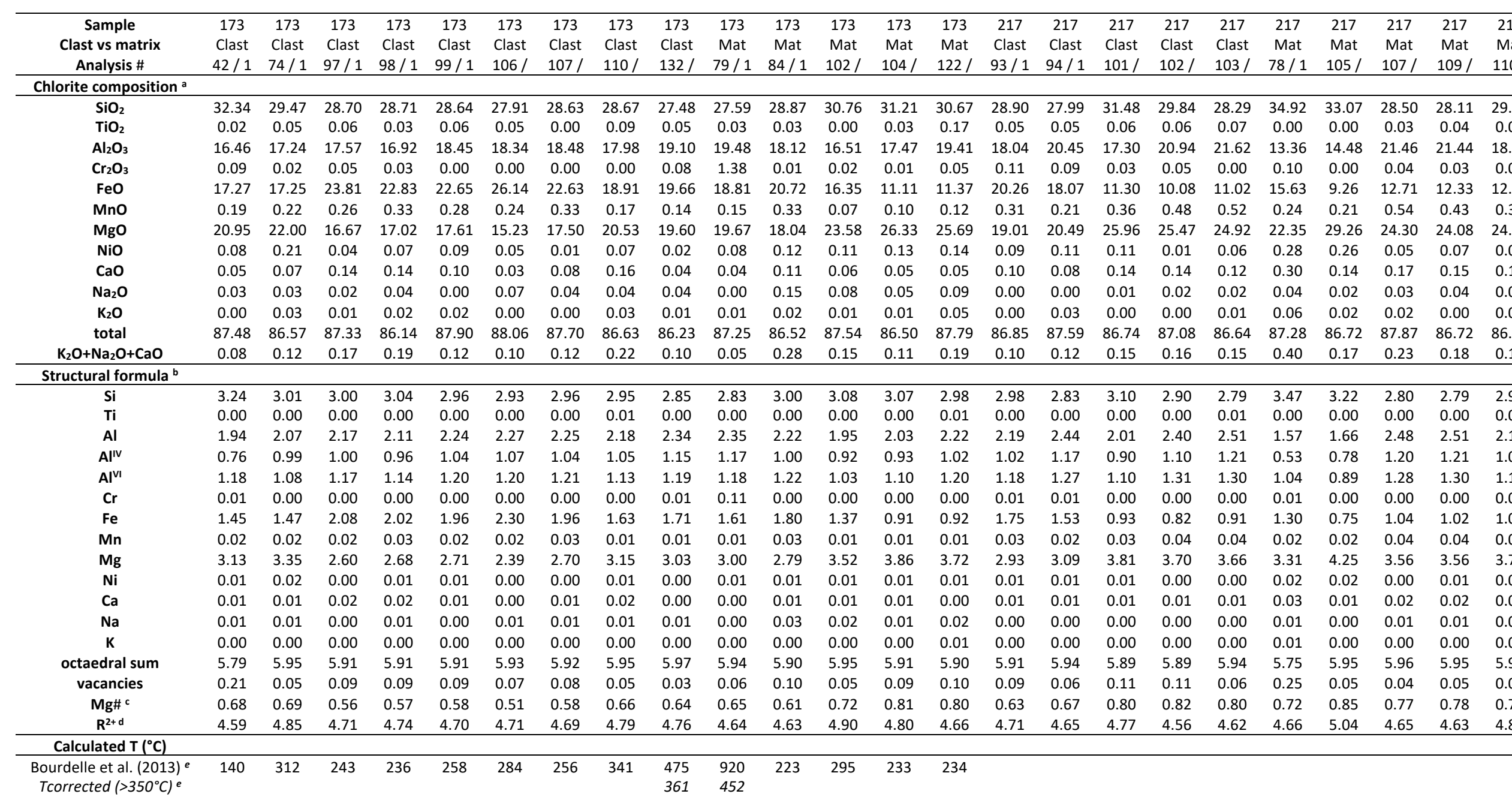


Table S3. In situ LA-ICP-MS trace element analysis (ppm) of 22 chlorite crystals from silicified samples.

\begin{tabular}{|c|c|c|c|c|c|c|c|c|c|c|c|c|c|c|c|c|c|c|c|c|c|}
\hline $\begin{array}{c}\text { Sample } \\
\text { Clast vs matrix } \\
\text { Analysis \# }\end{array}$ & $\begin{array}{l}195 \\
\text { clast } \\
\text { Chl1 }\end{array}$ & $\begin{array}{l}195 \\
\text { clast } \\
\text { Chl2 }\end{array}$ & $\begin{array}{c}195 \\
\text { clast } \\
\text { Chl2-1 }\end{array}$ & $\begin{array}{c}195 \\
\text { clast } \\
\text { Chl3b }\end{array}$ & $\begin{array}{l}155 \\
\text { clast } \\
\text { Chl1 }\end{array}$ & $\begin{array}{l}155 \\
\text { clast } \\
\text { Chl2 }\end{array}$ & $\begin{array}{c}155 \\
\text { matrix } \\
\text { Chl3 }\end{array}$ & $\begin{array}{c}155 \\
\text { matrix } \\
\text { Chl3-1 }\end{array}$ & $\begin{array}{l}155 \\
\text { clast } \\
\text { Chl4 }\end{array}$ & $\begin{array}{l}155 \\
\text { clast } \\
\text { Chl5 }\end{array}$ & $\begin{array}{c}155 \\
\text { matrix } \\
\text { Chl6 }\end{array}$ & $\begin{array}{c}218 a b \\
\text { clast } \\
\text { Chl1 }\end{array}$ & $\begin{array}{c}\text { 218ab } \\
\text { clast } \\
\text { Chl2 }\end{array}$ & $\begin{array}{c}\text { 218ab } \\
\text { matrix } \\
\text { Chl3 }\end{array}$ & $\begin{array}{l}218 a b \\
\text { matrix } \\
\text { Chl4 }\end{array}$ & $\begin{array}{l}218 \mathrm{c} \\
\text { clast } \\
\text { Chl1 }\end{array}$ & $\begin{array}{l}218 \mathrm{c} \\
\text { clast } \\
\text { Chl2 }\end{array}$ & $\begin{array}{c}218 c \\
\text { matrix } \\
\text { Chl3 }\end{array}$ & $\begin{array}{c}173 \\
\text { matrix } \\
\text { Chl1 }\end{array}$ & $\begin{array}{c}173 \\
\text { matrix } \\
\text { Chl2 }\end{array}$ & $\begin{array}{c}173 \\
\text { matrix } \\
\text { Chl3 }\end{array}$ \\
\hline $\mathrm{Ti}(47)^{\mathrm{a}}$ & $47^{b}$ & 5289 & 49 & 116 & 188 & - & 3816 & 384 & 144 & 110 & 218 & 248 & 13 & 29 & 28 & 66 & 215 & bdl & 23 & 25 & 17 \\
\hline Mn (55) & 2837 & 2720 & 2383 & 1985 & 3340 & 2319 & 241 & 267 & 2734 & 2733 & 525 & 386 & 75 & 93 & 48 & 485 & 1725 & 45 & 278 & 317 & 281 \\
\hline $\operatorname{Cr}(53)$ & 41 & 311 & 249 & 108 & 1022 & 689 & 124 & 92 & 40 & 55 & 231 & 169 & 30 & 69 & 56 & 44 & 746 & 15 & 720 & 1662 & 1107 \\
\hline Co (59) & 34 & 33 & 33 & 40 & 103 & 72 & bdl & bdl & 150 & 146 & 36 & bdl & bdl & bdl & bdl & 30 & 93 & bdl & 166 & 69 & 84 \\
\hline $\mathrm{Ni}(\mathbf{6 0})$ & 183 & 179 & 180 & 202 & 549 & 401 & 28 & 29 & 482 & 604 & 83 & 101 & 25 & 27 & 12 & 110 & 368 & bdl & 2639 & 1330 & 1689 \\
\hline $\mathrm{Cu}(63)$ & 19 & 20 & bdl & bdl & bdl & bdl & bdl & bdl & bdl & bdl & bdl & bdl & bdl & bdl & bdl & bdl & 38 & bdl & 280 & 202 & 15 \\
\hline $\operatorname{Zn}(66)$ & 207 & 172 & 159 & 152 & 225 & 161 & 16 & 14 & 198 & 180 & 40 & 29 & bdl & bdl & bdl & 25 & 108 & bdl & 1216 & 865 & 905 \\
\hline$V(51)$ & 172 & 241 & 156 & 134 & 473 & 405 & 45 & 18 & 209 & 164 & 35 & 39 & bdl & bdl & bdl & 66 & 198 & bdl & 29 & 29 & 26 \\
\hline
\end{tabular}

Analyses carried out at GeoRessources (Nancy, France) with a $193 \mathrm{~nm}$ GeoLas Pro ArF Excimer laser (Microlas, Göttingen. Germany) coupled with beam homogenization optics. Analyzed with an Agilent 7500c Quadrupole ICP-MS (Agilent, Santa Clara, USA) equipped with an octopole reaction system with enhanced sensitivity optional lenses (Cs type; Agilent). Internal standard: ${ }^{28} \mathrm{Si}$, calibrated from the mean value of several chlorite microprobe analyses.

a Element analyzed (isotope)

${ }^{b}$ Concentrations in ppm calibrated against the NIST SRM 610 silica glass reference using values given in Pearce et al. (1997). Absolute concentrations (ppm) calculated from equations in Longerich et al. (1996). 
1644 Table S4. Temperature of chlorite formation calculated from composition ( $R^{2+}$ and Si) of chlorite in equilibrium with quartz, with the thermometer 1645 of Bourdelle et al. (2013) for chlorites from matrix, clasts and both, in silicified samples.

1646

\begin{tabular}{crrrrr}
\hline $\mathbf{T}\left({ }^{\circ} \mathbf{C}\right)$ in matrix and clasts & $\mathbf{1 9 5}$ & $\mathbf{1 5 5}$ & $\mathbf{2 1 8 a b}$ & $\mathbf{2 1 8 c}$ & $\mathbf{1 7 3}$ \\
\hline Mean T & 250 & 265 & 291 & 294 & 276 \\
Median T & 244 & 273 & 303 & 301 & 257 \\
Minimum T & 156 & 113 & 152 & 234 & 140 \\
Maximum T & 350 & 492 & 402 & 349 & 452 \\
Standard deviation & 49 & 88 & 61 & 36 & 75 \\
Number of analyses & 46 & 40 & 36 & 22 & 14 \\
\hline T $\left({ }^{\circ} \mathbf{C}\right)$ in matrix & $\mathbf{1 9 5}$ & $\mathbf{1 5 5}$ & $\mathbf{2 1 8 a b}$ & $\mathbf{2 1 8 c}$ & $\mathbf{1 7 3}$ \\
\hline Mean T & 244 & 275 & 269 & & 287 \\
Median T & 236 & 272 & 284 & & 234 \\
Minimum T & 156 & 175 & 152 & & 223 \\
Maximum T & 350 & 365 & 340 & & 452 \\
Standard deviation & 48 & 63 & 64 & & 96 \\
Number of analyses & 37 & 11 & 9 & & 5 \\
\hline T $\left({ }^{\circ} \mathbf{C}\right)$ in clasts & $\mathbf{1 9 5}$ & $\mathbf{1 5 5}$ & $\mathbf{2 1 8 a b}$ & $\mathbf{2 1 8 c}$ & $\mathbf{1 7 3}$ \\
\hline Mean T & 272 & 262 & 298 & 294 & 270 \\
Median T & 269 & 273 & 313 & 301 & 258 \\
Minimum T & 197 & 113 & 194 & 234 & 140 \\
Maximum T & 332 & 492 & 402 & 349 & 361 \\
Standard deviation & 50 & 96 & 59 & 36 & 66 \\
Number of analyses & 9 & 29 & 27 & 22 & 9
\end{tabular}

